\title{
HISTORIC
}

\section{AMERICAN TREES}

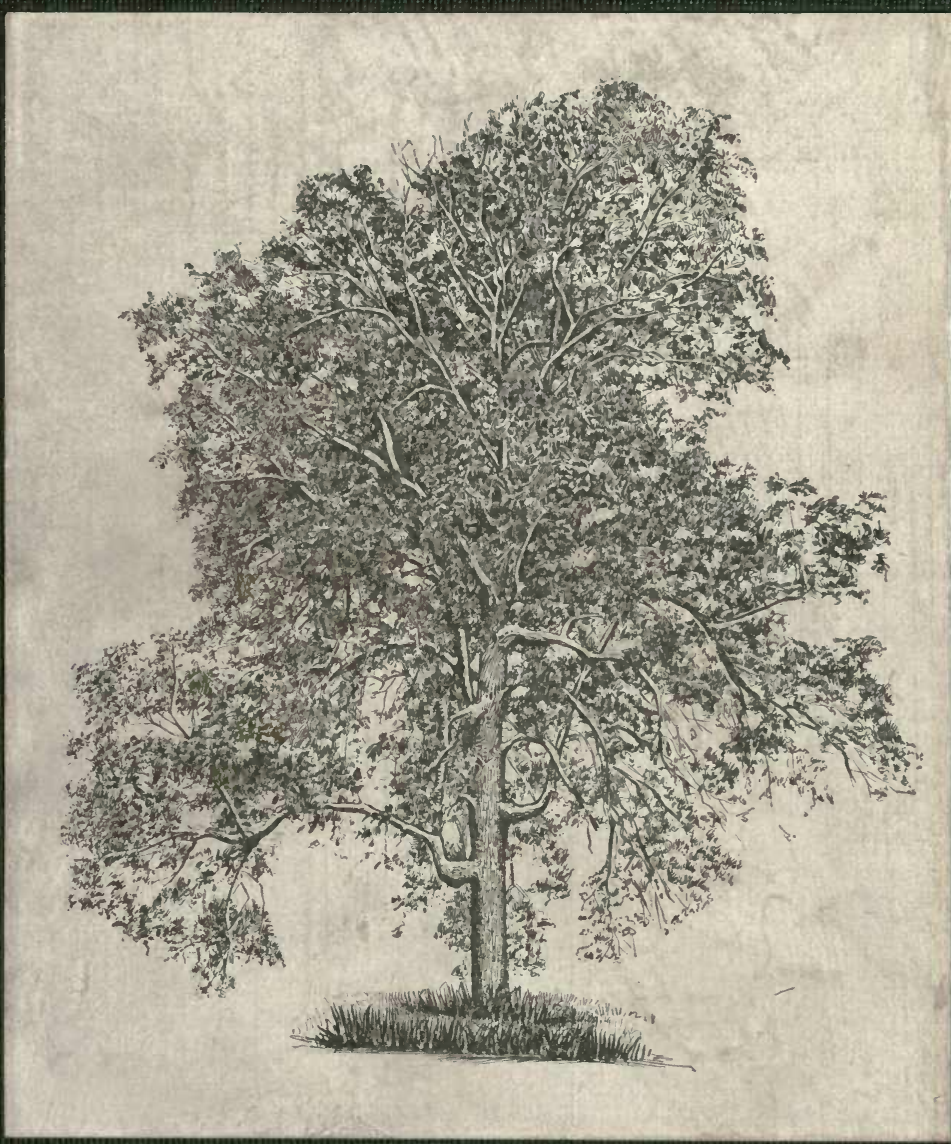




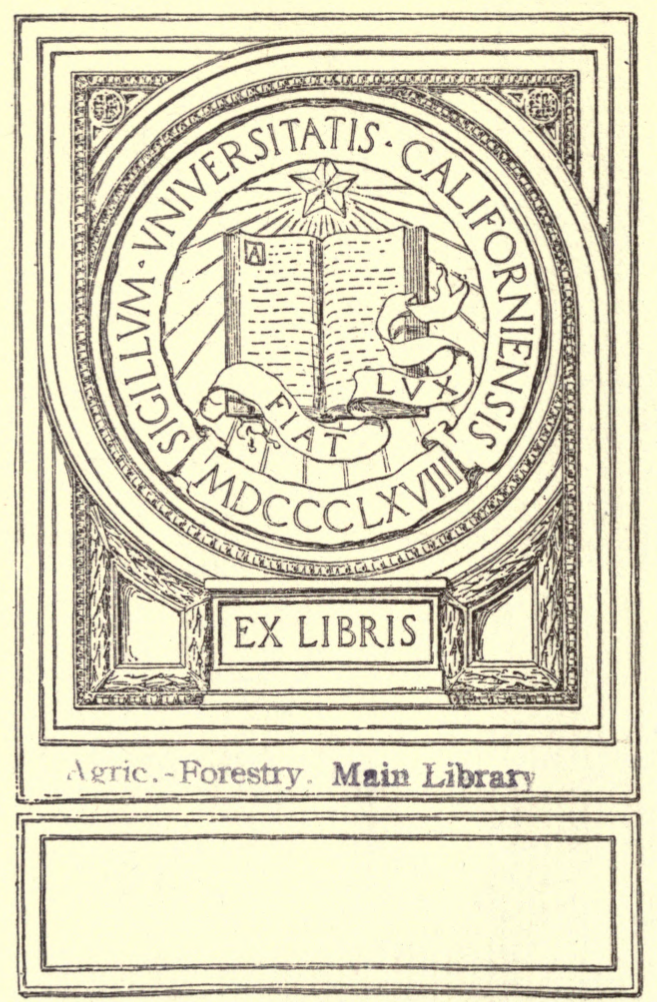






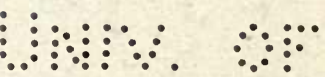

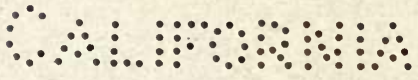




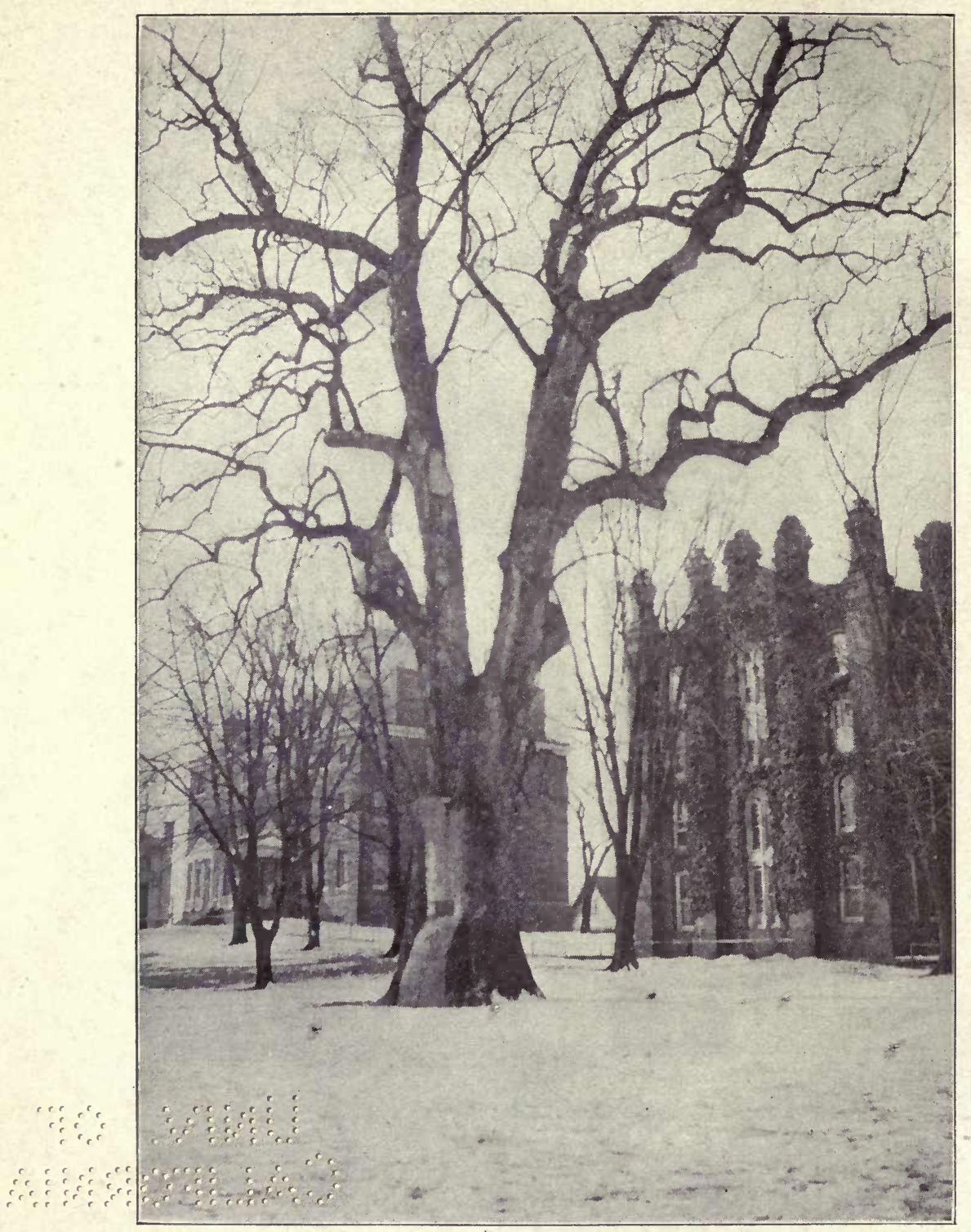

LIBERTY TREE OF ANNAPOLIS

Photo by K. S. Nicholson 


\section{HISTORIC \\ AMERICAN TREES}

\section{By \\ KATHARINE STANLEY NICHOLSON}

Photographs by the Author and Others

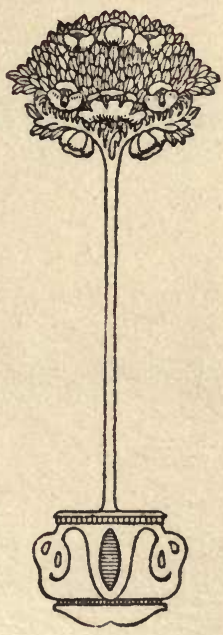

NEW YORK

FRYE PUBLISHING COMPANY 


\section{SD 383 \\ N 5}

Copyright, 1922, by

KATHARINE STANLEY NICHOLSON

Agric,-Forestry. Main Library

$\because \because \vdots \quad \vdots \because \vdots \vdots \vdots \vdots \vdots \vdots \vdots \vdots \vdots 0$

$\therefore \because \because \because \because \vdots \vdots \cdots \cdots$ 


\section{DEDICATED}

by permission

to

\section{Hnunahle Jilliant (c. Spraul}

Governor of Pennsylvania

As A Slight Token of Appreciation of

His Splendid 'Service

In Forest Conservation

COPY

\section{THE GOVERNOR'S LETTER}

\section{EXECUTIVE DEPARTMEN'T \\ HARRISBURG}

\section{The Bobernor}

MISS KATHARINE STANLEY NICHOLSON

22 South Eighteenth Street

Philadelphia, $\mathrm{Pa}$.

Dear Friend:

Your gracious note of the $13^{\text {th }}$ is at hand. Of course, 1 should greatly appreciate such an honor as the dedication of your book to me, and I only wish that I might have the satisfaction of feeling that I really deserved such a distinction.

I am greatly interested in what you are planning and I trust that your work will be cminently successful.

With appreciation and kind regards, I am,

Sincerely yours,

(Signed) WM: C. SPROUL 


\section{TABLE OF CONTENTS}

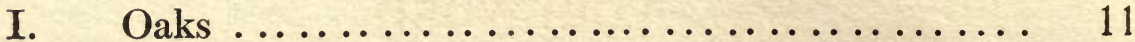

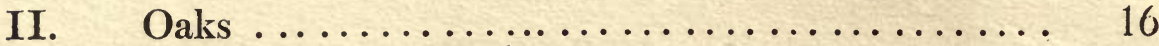

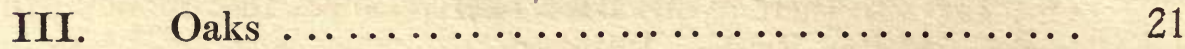

IV. Poplars $\ldots \ldots \ldots \ldots \ldots \ldots \ldots \ldots \ldots \ldots \ldots \ldots, 26$

V. Poplars-Sycamores ................ 31

VI. The Penn Treaty Elm ............... 38

VII. Elms $\ldots \ldots \ldots \ldots \ldots \ldots \ldots \ldots \ldots \ldots \ldots \ldots \ldots, 42$

VIII. $\quad$ Elms ............................. 44

IX. Sugar Maples .................... 52

X. Memorial Trees .................... 56

XI. Willows - Inwood Tulip Tree-Stockton Catalpas -Hamilton's Trees-Treaty Tree of Gross Ile ....................... 62

XII. Cypress-Yews $\ldots \ldots \ldots \ldots \ldots \ldots \ldots \ldots \ldots \ldots, 67$

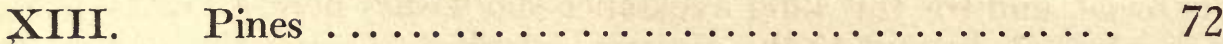

XIV. Pines-Sequoias $\ldots \ldots \ldots \ldots \ldots \ldots \ldots \ldots \ldots \ldots$

XV. $\quad$ Nut Trees ..................... 81

XVI. Nut Trees-Indian Trail Trees ........... 86

XVII. Mulberries ......................... 90

XVIII. Pears-The Traveling Nursery ............ 96

XIX. Apples ....................... 101

\section{LIST OF ILLUSTRATIONS}

Indian Trail Tree .....................Front Cover

Liberty Tree of Annapolis .................. Frontispiece

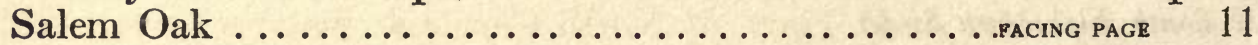

Largest Oak in Pennsylvania .................. 21

Sycamore and Lafayette's Headquarters ............. 31

Pringle Sycamore ............................ 35

Penn Treaty Elm ......................... 38

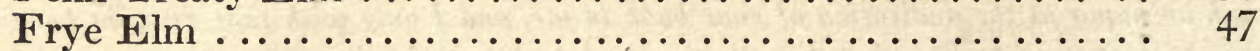

Roosevelt Sugar Maple ....................... 56

Napoleon Willows .......................... 62

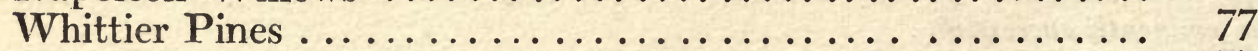

Sequoia ................................ 77

Daniel Boone's Bar Tree ....................... 81

Black Walnut of Stony Point .................... 81

Mulberry Walk ............................ 90

Box Hedge of Count Du Barry ................. 90 


\section{FOREWORD}

"Old Trees in their living state, are treasures that money cannot buy," wrote Walter Savage Landor.

Treasures, indeed, though too seldom appreciated! Intimately associated as they are in many instances with our National life as well as with local events, much of the history of America is written in the story of her trees, living or otherwise, and can be traced through a study of the part they have played in connection with its development. Living Links in the chain of human interests that spans the centuries, such trees possess a unique historic value, and should be carefully preserved.

During the preparation of this volume, gratifying proof of the widespread interest in our subject has been received by the writer. From many quarters have come helpful suggestions and valuable material, and for this kind assistance she wishes here, to make grateful acknowledgment to the various historical societies throughout the country, also to the following individuals and books:

Mr. James F. Sullivan, Mrs. Margaret M. Halvey, Managing Editor of The Starry Cross; Mrs. Frederick Winslow Taylor, Mr. Fred Shelton, Philadelphia; Dr. John W. Harshberger, University of Pennsylvania; Mrs. M. E. T. Chapin, Miss Sophia K. Seabury, Miss Alma Dunbar, Mrs. E. P. Gardner, Miss E. Frye Barker, Miss Nettie Hustis, Mr. Stewart H. Burnham, Mr. William Markham, New York State; Mr. Harold Rugg, Dartmouth College, New Hampshire; Mr. Carl Bannwart, Supt. Shade Tree Commission, Newark, N. J.; Mr. Ransom Kennicott, Forester, Cook County Forest Preserve, Ill.; Miss Delia Harris Maddox, Baltimore, Maryland; Mr. Lucien Lamar Knight, State Historian of Georgia; Mr. J. C. McWhorter, of West Virginia; Dr. John H. Schaffner, Ohio State University; Mr. A. C. Dart, of North Carolina; Senator George P. Morehouse, of Kansas; Mr. Robert G. Sproul, Secretary, Save the Redwoods League, California; Mr. George Himes, of Oregon; Mr. William E. Foster of Rhode Island, and others who have generously contributed information that has proved most useful in the preparation of this book. Reports.

American Scenic and Historic Preservation Society, Annual

American Forestry Magazine, 1918-1921.

"Annals of Philadelphia," by John F. Watson.

"Border Settlers of Northwestern Virginia," by L. V. McWhorter. 
Bureau of American Ethnology, Smithsonian Institute, Bulletin 30 .

"Brief History of South Dakota," by Doane Robinson, Secretary, State Historical Society of South Dakota.

"Centennial Biographical History of Richland and Ashland Counties, Ohio," by A. J. Baughman.

"Chronicles of Colonial Maryland," by James Walter Thomas.

"Daniel Boone," by John S. C Abbott.

"Daniel Boone," by Lucille Gulliver.

"First Founders in America," by William Howard Fitch, M.D.

"Georgia's Landmarks, Memorials and Legends," by Lucian Lamar Knight. Alden.

"Guide to Annapolis," by William O. Stevens and Carroll S.

"Historic Highway of America," by Archer Butler Hulbert. Hasbrouck.

"History of Dutchess County, New York," edited by Frank

"History of the Great Republic," by H. A. Guerber.

"History of Detroit and Michigan," by Silas Farmer.

"History of Indiana," by Wm. Henry Smith.

"History and Stories of Nebraska," by A. E. Sheldon.

"Historic Trees of Massachusetts," by James Raymond Simmons.

"Hoosac Valley, (The)," by Grace Greylock Niles.

Indiana Arbor and Bird Day Annual.

Journal of the New York Botanic Garden.

"Legends of Trees and Flowers," by Charles Skinner.

"Lives of Famous Indian Chiefs," by Norman B. Wood.

"Marking the Santa Fé Trail," by Mrs. T. A. Cordry.

Memoirs of the Pennsylvania Historical Society.

"Memorials of John Bartram and Humphrey Marshall," by William Darlington, M.D., L.L.D.

"Memorials of a Half Century," by Bela Hubbard.

Minnesota Historical Society Historical Collections.

Michigan Pioneer and Historical Society, Vols. XIV and XXII.

National Geographical Magazine.

Ohio Archæological and Historical Publications, Vol. XXII.

Ohio Archæological and Historical Quarterly.

Proceedings of the Delaware County Institute of Science.

"Reminiscences of Famous Georgians," by Lucien Lamar Knight.. 
"Review of Facts and Observations Made by Naturalists, Botanists, Historians and Travelers, on the Properties and Productions of the Sugar Maple Tree," by E. Jones, published in London, in 1832.

"Roger Williams," by Oscar S. Strauss.

"Secret of the Big Trees, The" by Ellsworth Huntington, Ph.D., F.R.G.S., Harpers' Magazine.

"Storming of Stony Point," by Henry P. Johnston, M.A.

"Story of Tennessee," by James Phelan.

"White Doe (The) ; the Fate of Virginia Dare," by Sallie Southhall Cotten.

Wisconsin Archæologist, Vol. XV.

Saunders.

"With the Flowers and Trees in California," by Charles Francis

Zoological Society Bulletin, September, 1919.

THE AUTHOR 



\section{HISTORIC AMERICAN TREES}




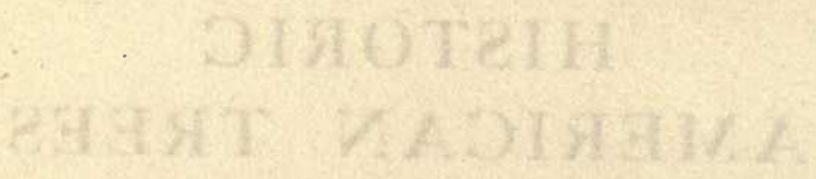


(1) 


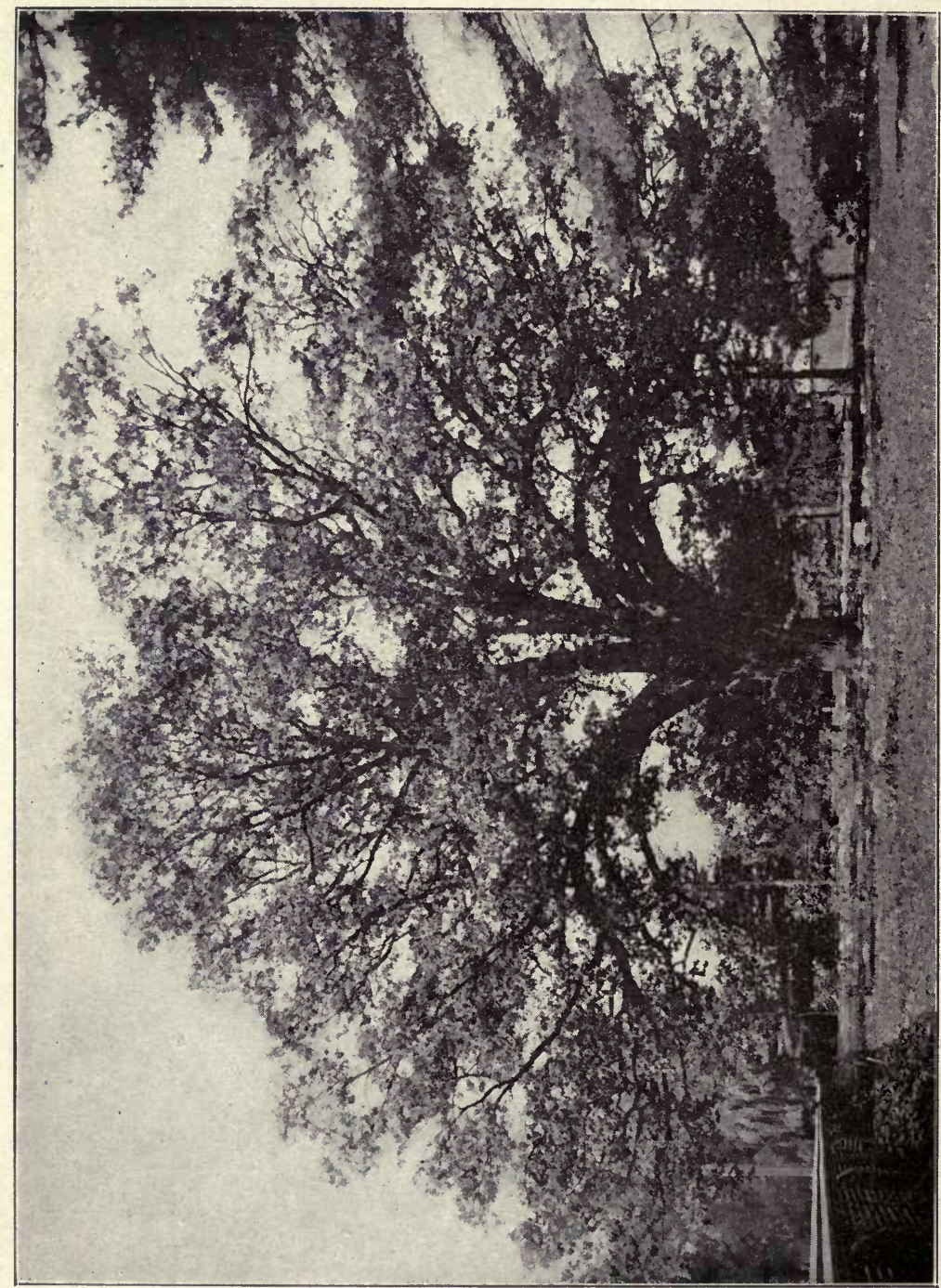

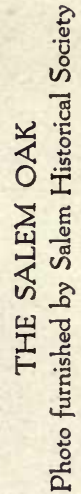




\title{
CHAPTER I
}

\author{
The Wi-ten-a-ge-mot Oak-The Charter Oak-The Pelham Oak- \\ The Fox Oaks-The Salem Oak-The Wadsworth Oak-The \\ Rappite Oak.
}

\section{The Wi-Ten-A-Ge-Mot OAK}

This veteran oak is still standing on the ancient Indian Council Ground at Schagticoke, N. Y. It is in the rear of the old Knickerbocker Mansion where Washington Irving was a frequent visitor and where he discovered the original of his famous character, Dietrich Knickerbocker.

Nearly two hundred and fifty years ago, at the close of King Philip's War, Governor Andros, of New York, planted the oak, the only Tree of Welfare ever dedicated to the Indians.

In 1676, Governor Andros formed a Board of Indian Commissioners, at Albany, and, able diplomat that he was, set about preventing the exodus to Canada of discontented Indians from the Hudson River and Hoosac Valley and influencing them to stay in their own country. It was during this visit to Albany that he planted the Tree of Peace at Schagticoke, for the purpose of strengthening the friendship between the Hoosac and Mohawk Indians, and between the Militia at Fort Albany and the River Indian scouts; and in honor of the occasion, called a meeting of the conference known as The Wi-tena-ge-mot or Assemblage of the Wise, named after the National Assembly of early Saxon times prior to the Norman Conquest. About one thousand warriors, representatives of the Iroquois, Hoosacs, Pequots, Narragansetts, Pennacooks, Delawares, Mohawks and other nations obeyed the summons to the conference.

Governor Andros and his staff, the royal militia in their brilliant uniforms, the Board of Indian Commissioners, judges and clergymen completed the gathering. Two Dutch pastors of Albany and two Jesuit Priests of the Mohawk Missions offered prayer while the Calumet or pipe of peace was solemnly passed around, whites as well as red men smoking it in turn, to seal their compact of good will.

Belts of wampum embroidered with the Swastika were given by the Indians to their white friends, and the Governor presented the River Indian Scouts with tobacco, pipes and uniforms. Three of the Chiefs broke their bow-strings and buried the hatchet at the foot of the newly planted oak. Soquon, the orator of the Hoosacs, announced that the blood had been cleansed from the blade of the hatchet just buried, and that the warriors would henceforth dance in peace beneath the Tree of Welfare.

The ceremony and the compact of friendship, symbolized by the planting of the tiny oak, were long and lovingly remembered by the 
Indian natiors; ard they held the Tree of Peace in deep regard. Those Indians living on the east shore of the Hudson told Governor Bellemont, of New York, about the event as follows: "It is now six and twenty years since we were almost dead when we left New England and were first received into this government; then it was that a tree was planted at Shakkook, whose branches is spread so that there is a comfortable shade under the leaves of it; we are unanimously resolved to live and die under the shadow of that Tree, and pray our Father to nourish and have a favorable aspect towards that Tree, for you need not apprehend that tho any of our people go out a hunting, they will look out for another country, since they like that place called Shakkook so well."

Having promised a Council Tree to the Mohawk Scouts also, Governor Andros planted it, probably in 1676, on the shore of the Tomhamac River, but it did not fare as well as the Wi-ten-a-ge-mot Oak, being injured by lightning. "Our neighbors, the Mohawks, have not been so fortunate," said Soquon to the Governor, "for their tree burnt. We have been so happy and fortunate that our number is increased to that degree that we cannot all be shaded by one tree, and, therefore, desire that another tree besides that at Schagticoke may be planted for us."

The Wi-ten-a-ge-mot Oak is now in its third century of life, its circumference measures twenty-two feet, and its shade covers an acre. But it shows unmistakable signs of decay, and unless this can be arrested, it will not be many years before one of the most historic trees of the continent will have vanished.

\section{The Charter Oak}

The first settlers at Hartford, Conn., found there a white oak, tall and spreading, already full of years - its age even then being estimated at several centuries - that was a valued land mark of the Indians. They begged the pioneers to spare the ancient oak while clearing the forest growth, saying, "It has been the guide of our ancestors for hundreds of years, as to the time of planting our corn, when the leaves are the size of a mouse's ears, then is the time to put the seed into the ground." Granting the Indians' request to leave the ancient oak untouched, the white men builded better than they knew, for in a few years it had rendered them a service of great worth.

In 1687, Governor Andros, whom King James had appointed Governor of all New England, attended a session of the Colonial Assembly at Hartford, and demanded its charter. In an instant, the lights in the hall were extinguished, and relit, but the historic document had vanished from the table where it lay. Captain Wadsworth had carried it away and concealed it in the old oak's hollow trunk.

Strangely enough, King Charles II, who had granted the charter, had himself been obliged to take refuge in the trunk of an oak, eleven years previous, after the battle of Worcester, England. Later, his 
friend, Dr. Halley, the astronomer, christened a constellation in the heavens, "Robur Caroli" (Charles' Oak), in memory of the event.

Shortly after his demand for the charter, Governor Andros was recalled, and English courts having decided that, as Hartford had never relinquished its charter, it was still in force, the precious parchment was brought to light again, and the colonial government was continued under its provisions.

Through another century and a half the Charter Oak remained, loved and venerated by many admirers, and when in 1856, a heavy storm laid it low, "the bells of the city were tolled, and a band of music played funeral dirges over its ruins."

\section{The Pelham Oak}

In 1654, Thomas Pell, of Fairfield, Conn., bought property north of the Harlem River, "embracing all that tract of land called Westchester," in what is now New York State. Beneath the shade of a large white oak, which has ever since been called by his name, the deed was signed by the Indian Chiefs Manninepol, Annhook, and five other Sachems from whom he purchased the land for "two guns, two kettles, two coats, two adzes, 2 shirts, one barrel of cider and 6 bits of money"; the value of the payment is estimated to have amounted to eight pounds, four shillings and six pence.

Nine days before the transaction, a meeting of the Director General and Council of New Netherlands had taken place, and it had been resolved to forbid the English settling on any soil which, the Government claimed had been "long before bought and paid for," and to order them "to proceed no farther, but to abandon that spot."

Pell, being one of the chief offenders, it was reported by the attorney of the New Netherlands, that he had "dared against the rights and usages of Christian countries to pretend that he bought these lands of the natives," and that he was making a settlement there. He continued to hold the land, however, ignoring all objections, and when at length the Dutch surrendered, in .1664, became its undisputed owner. In 1666, Governor Nicholls, of New York, confirmed a large part of Pell's grant, and "erected a township or manor; the proprietor rendering and paying in fealty therefor yearly, unto his Royal Highness, James, Duke of York, or to such governor as should, from time to time be by him appointed, as an acknowledgment, one lamb upon the first day of May, (the feast of S. S. Philip and James)."

For more than two hundred and fifty years, the old oak had been famed as the landmark where the beginnings of historic Pelham Manor were made. It is said to have stood on the Post Road, between Pelham Bridge and the entrance to the Bartow place. About one hundred and seventy-five feet south of the bridge, is an oak stump, surrounded by an iron railing, believed by many to be the remains of the treaty tree. According to the report of the American Scienic 
and Historic Preservation Society, however, this is incorrect, and nothing now is left of the fine old oak but the record of its fame.

\section{The Fox OAKs}

In 1661, John Bowne, a noted man of his time, built his house in Flushing, N. Y. He was "so zealous a Quaker that he was exiled to Holland by Governor Stuyvesant, for his adherence to the sect, and did not return home for two years."

Opposite his home stood two immense oaks, under whose shade George Fox, Founder of the Society of Friends, preached to the Indians in 1672. Under the same trees, Friends were accustomed to hold their meetings, when the crowds became too large to be accommodated in Mr. Bowne's house. One of the Fox Oaks, as the old trees were named in honor of the distinguished preachers, lived till 1841, the other surviving a few years longer. They were estimated to be about five hundred years of age.

\section{The Salem Oak}

Another tree long associated with the Society of Friends is the fine old oak at Salem, N. J. When the land on which it stands came into the possession of the Society, in 1680 , the tree was comparatively young and slender though perhaps not even then in its first youth. It is believed to be between three and four hundred years of age, possibly much older; one of its largest branches fell in a severe storm in the autumn of 1920, and showed two hundred and seventy-five rings of annual growth. The old oak shades one hundred and seventeen feet of ground in the Friends Cemetery, and looks the part of a noble monarch of the primeval forest. One can fancy it rich in memories of long-past but stirring times, for it has watched over the development of the town of Salem from its birth, as from time to time the little community has borne its part in the storm and stress of history.

The old oak bids fair to be one of the longest-lived of American trees, for when signs of decay become evident, the aid of tree surgeons has been promptly enlisted to strengthen and preserve it intact.

\section{The Wadsworth OAK}

Th Wadsworth Oak, or Big Tree, on the Genesee River, at Genesee, N. Y., was long a tree of note. It was a swamp white oak, its leaves turning a dull yellow in autumn, instead of the rich red tint of those of the white oak. Measuring twenty-seven feet in circumference, it was venerated on account of its size, and the Seneca Indians named the surrounding country Big Tree, in its honor. Near it, in 1797, a treaty was made between Robert Morris and the Senecas, by which they conveyed to him the greater part of their territory. 
In 1851, the Big Tree came to its end in a heavy freshet which washed away the river bank. A piece of its trunk was placed on the Letchworth estate, in the neighborhood, near an old Indian Council House, which had been moved there to be kept as a valuable relic, after it had been abandoned by its former owners of the Senecas tribe.

\section{The Rappite OAK}

In 1815, George Rapp, a native of Wurtemburg, Germany, purchased 30,000 acres in Posey Co., Ind., near the confluence of the Wabash and Ohio Rivers, and founded the community of New Harmony. The little settlement was governed by the principles of the New Testament as he understood them, and was modelled after his former one in Pennsylvania.

On the night of their arrival at their new home, the colonists slept under the shade of a large tree, which became known as the Rappite Oak. Near it, their leader built his house, connecting it by an underground passage with the fort. Traces of the quaint old settlement still remain, in the odd little houses, none of which boasted a front door, and one wing of the large church built in the form of a Greek cross.

During long years the historic rights of the old oak were respected by later residents in the old home, and though showing the approach of age, it was left standing. In 1900, a summer storm laid it low, "after about ninety years of experience in song and story." 


\section{CHAPTER II}

The De Soto Oak-The Catholic Oak-The Wesley Oak-Teach's Oak-Troo Royal Oaks-Whipping Tree at Peekskill-Two Oaks that Own Themselves-Indian Oak.

\section{The De Soto OaK}

Both history and legend have given fame to the handsome, spreading oak upon the grounds of the Tampa Bay Hotel, Fla., whose branches shade an area of one hundred and twenty feet.

In 1539, Ferdinand De Soto, whose name the tree bears, became Governor of Florida. He was very fond of resting beneath the oak, and is believed to have made a treaty with the Indians under its shade. More than three hundred and fifty years later, during the SpanishAmerican War, General Nelson A. Miles made his headquarters beneath the venerable tree.

\section{The Catholic Oak}

In 1635, the Rev. William Blackstone, a clergyman of the Church of England, moved from Boston to what is now the village of Lonsdale, R. I., and is remembered as the first white man to settle in that State. Close by his grave, near the corner of Broad and Mill Streets, Lonsdale, stands the immense oak, its trunk measuring twenty-seven feet at the ground-level, which he mentions in his writings as being in its prime in his day.

The old oak has a singular history. In 1843, the Rev. James Cook Richmond, a missionary of the Episcopal Church, passing on his way to preach at a neighboring town, paused under its branches, exclaiming, "What a beautiful tree that is! I think I will hold services here next Sunday." As if to form a natural pulpit, two large roots on one side of the tree enclosed a hollow, where he stood while conducting the services that soon became immensely popular. The first one was held on Whit Sunday, June 4, 1843, when Mr. Richmond christened the tree the "Catholic Oak," evidently using the adjective in its broadest sense as signifying "universal," since the services were intended for all, irrespective of creed.

Crowds attended his first open air service of the Episcopal Church in this country, it having been estimated that there were more than six hundred persons present, many of whom never attended church, but were doubtless attracted by the novelty of the proceeding.

After preaching beneath the oak for several months, Mr. Richmond was sent to another field, but returned every year, to hold service under the tree on Whitsunday. About the year 1847, he went again to Europe, taking with him an acorn from his beloved oak, and planting it in England where it has grown and flourished. 
An iron railing has been placed around the Catholic Oak, at Lonsdale, with a tablet commemorating the history of the famous landmark which may yet remain through another generation.

\section{The Wesley Oak}

On St. Simon's Island, Ga., less than half a mile from the ruins of Fort Frederica, stands a gnarled and ancient live oak, under whose wide-spread branches tradition says that the Wesleys preached, the pioneers of Methodism in this country.

The old tree is a memento of events enacted near it, of far more stirring character. Numbering its years at not less than two hundred, probably many more, its growth was contemporary with the earliest history of English colonists in Georgia; with the landing on her coast of the good ship Anne, which brought General James Edward Oglethorpe, "the most illustrious Englishman to cross the sea during the period of American colonization," when he came with his followers to establish in the New World a refuge for the debtors of England; and with his valiant conquest of the French and Spanish invaders who threatened the rights and liberties of English settlers in America.

"From the outstretched limbs of the old oak," says Mr. Lucien Lamar Knight, the historian, "trail the pendant mosses, giving it an appearance of great solemnity and beauty, and making it the picturesque embodiment of the austere memories which cluster about the sacred spot." Two hundred feet in height, it stands at the gate of the churchyard of Christ Church, on whose parish-register are the names of some of the earliest settlers on the island, and under its broad shade sleep many generations.

The tree is on the direct road to Fort Frederica, built in 1735, by General Oglethorpe, as a defence against Spanish power, and named for Frederic, Prince of Wales.

\section{Teach's OaK}

The old tree, which stands on a little peninsula in a creek tributary to the Neuse River, at Oriental, N. C., was a prominent figure in the early history of the State. Long before civilization had placed a lighthouse or other means of guidance on those shores, the big oak served to point the way for many a mariner.

It is associated with the pirate Edward Teach, a daring and troublesome character of those early days. Because of his thick, black whiskers, he went by the name of Blackbeard. He was an Englishman, and in his youth a sailor under a pirate captain named Kornagold, and proved himself an apt pupil. In 1718, he was given command of a ship captured by his master, and set sail for American waters.

The coasts of North Carolina and Virginia were Teach's special hunting-ground. It is said that when pursued by larger vessels which 
could not follow him into shallow water, he took refuge in Albemarle and Pamlico sounds. The old oak was the favorite rendezvous of himself and his crew, and large holes were later dug around its foot, in fruitless efforts to discover the treasure he was known to have amassed and supposed to have concealed there.

When the English king, hopeless of controlling the lawless rovers who terrorized sailors far and near, offered a pardon to all of them who would surrender and live as peaceable citizens, Teach availed himself of the opportunity. He soon tired of the monotony, however, and started out again, a menace to all he met. At length, Governor Spottswood, of Virginia, brought matters to a head by dispatching Lieutenant Maynard in search of him. After a sharp fight, Teach was killed, and his head was fastened to the bowsprit of Maynard's ship, as a trophy. Tradition has it that the headless body swam round Ocracoke Island nearby, in quest of the pirate crew and their vessel.

\section{Two Royal Oaks}

Two American trees have each borne the title of Royal Oak. One of them, whose fame is perpetuated in the village of that name, near the spot where it stood, in the vicinity of Easton, Md., had grown to such a size that it was supposed to have been standing before the discovery of the New World. Soldiers who fought in the Revolution were drilled under its branches, but its name originated in an occurrence of the War of 1812.

During that struggle, a British ship came to anchor opposite the town of St. Michaels, Talbot County, Md., a few miles from the veteran oak, and opened fire.

The inhabitants, who were unprotected, resorted to a bit of strategy that proved highly effective. Hanging lighted lanterns in the tops of the high trees, they deceived the enemy into mistaking them for the lights of the town, with the satisfactory result that their shots passed harmlessly overhead.

For a long time, two cannon balls said to be of "local fame" were suspended from the limbs of the Royal Oak, and after its fall in 1864, they were placed on a locust post nearby.

A white oak bearing the same distinguished name, stood on a plain northeast of the Indian trail leading from Detroit to the village of Pontiac, Mich., and the township of Royal Oak of that neighborhood is named in its honor. The reason for its august title seems, however, decidedly obscure, as its associations are chiefly with doings of the red men. There is a tradition that, beneath it, an unfriendly meeting occurred, Chief Pontiac and representatives of another tribe being the interested parties. As late as 1825, the scars of arrows, tomahawks and bullets were said to be visible in its wood. It figured, also, as a boundary tree, when, in 1819 Governor Case laid out a road "from Woodward Avenue, Detroit, to the end of the road built by 
the United States troops, then west to a large oak marked $H$, near Indian trail, then west to Main Street in Pontiac Village, then to the end of Main Street."

\section{Whipping Tree at Peekskill}

An oak of old-time associations, that is still flourishing, is the "Whipping Tree" at Peekskill, N. Y. Beneath it, strenuous correction was administered in Revoluntionary times to deserters from the American cause. The tree is situated in a wide field adjoining the grounds of the Van Cortland Manor-House, Washington's headquarters when he was in Peekskill. Here Lafayette, Rochambeau, Baron Von Steuben and other famous soldiers were entertained. Pierre Van Cortland, the owner, was Lieutenant-Governor from $\mathbf{1 7 7 7}$ to 1795, and acting-Marshal of the Equestrian Provincial Congress, which Congress was more than once obliged to hold its sessions on horseback, and legislate to meet emergencies. He also served as President of the Convention that was responsible for the new Federal constitution of 1781.

\section{Two Oaks That Own Themselves}

A fine old oak, near the town of Athens, Ga., fell heir, about a century ago, to sufficient land to protect it from invasion as long as Nature shall permit it to stand. In the Town Clerk's office is recorded the deed dated in 1820, by which its owner, the Hon. W. H. Jackson, "for and in consideration of the great affection which he bears said tree, and his desire to see it protected, has conveyed and by these presents does convey unto the said tree entire possession of itself, and the land within eight feet of it on all sides." Thus insured against any encroachment upon its rights, the old oak flourishes, today, its age exceeding three hundred and fifty years, and is a tree of noble proportions. On a tablet under its branches is inscribed a quotation from the deed. By virtue of being the first tree distinguished as a landowner it seems fully entitled to rank as historic.

An oak of California, that is claimed to rival in size the Sir Joseph Hooker oak at Chico in the same State, is fortunate in having been liberally provided for by Mr. A. E. Wiltse, of New York City, who has set apart forty acres surrounding the tree, in order that it may be preserved for generations. The oak has a circumference of thirtyone feet, and shades a radius of one hundred and thirty feet. Its age is estimated at from six hundred to seven hundred years.

\section{INDIAN OAK}

Maple Hill, Geneva, N. Y., the beautiful estate where Lafayette was entertained in 1825, possesses seven acres of ancient forest trees known as Sylvan Grove. One of these trees, called Indian Oak, was a favorite meeting place of Chief Red Jacket and his companions. 
This noted chief, "the Indian Demosthenes," was of the Seneca tribe, and was the greatest orator of the Six Nations.

He was a young man at the time of the Revolution, and was often employed by the British officers as a messenger or "runner." Both on account of his great physical endurance and his eloquence, he was able to be of great service to them. In return, the officers presented him with a handsomely embroidered scarlet jacket which he wore with great pride; and during the war they kept him supplied with similar coats. This costume earned for him the title which clung to him through life. After the close of the war, the Americans were accustomed to present him with a red jacket whenever they wished to please him.

The Indian Oak is no longer standing, but a granite rock has been placed on the site where it grew, a temporary stone of remembrance, until a permanent monument shall mark the historic spot. 



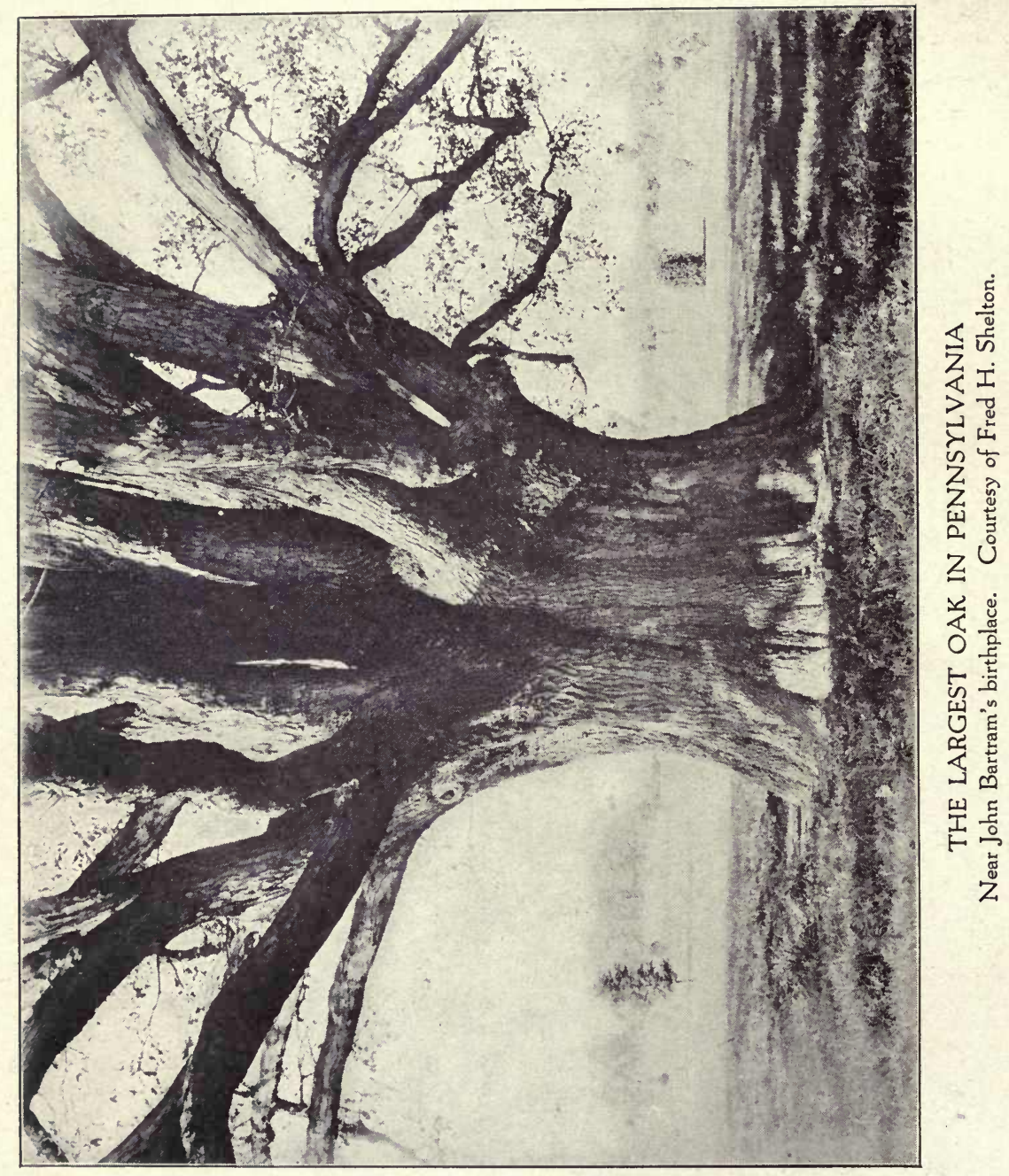




\section{CHAPTER III}

\section{The Bartram Oaks-Corner Oaks-"Struck-by-the-Ree's Tree"- Washington Oak-Red Oak at Chesterfield-Council Oak of the Santa F'é 'Trail.}

\section{The Bartram Oaks}

In the southwestern section of Philadelphia, Penn., on the bank of the Schuylkill, stands a quaint old house, built in 1731, by John Bartram, "The Father of American Botany." Surrounding it, and covering from six to seven acres, lies the famous garden which he cultivated through half a century; a garden which, during his lifetime was a favorite resort of Washington, Franklin and other men of note, and which has survived to our own days as a city park and a centre of interest to nature-lovers.

Many unusual and interesting trees and shrubs collected by Bartram during his travels through the then unknown region of the eastern and southern portions of the United States, or sent to him by friends at home and abroad, found their way into the garden and a number have survived to our own day. One of the most noticeable of these trees, the heterophyllus oak, so-called because bearing leaves of various shapes, still stands guard just south of the old house.

An oak of this description, one whose leaves did not all follow the same pattern, was of course a novelty, and Peter Collinson, a distingushed naturalist of London, to whom Bartram was in the habit of sending boxes of botanical specimens, evidently felt somewhat slighted at receiving no seeds of such an unusual tree. On March 5, 1770, he wrote to Bartram about it as follows: "Pray what is the reason I have no acorns from that particular species of oak that Doctor Mitchell found in thy meadow"? Adding the Latin name, "Quercus heterophyllus," so that there would be no doubt to what he referred.

He also had requested, many years previous, acorns of the Willow-leaved Oak and of the White and Swamp Spanish Oak, all of them familiar to John Bartram in his travels in American wilds. Perhaps Collinson voiced his impatience at the length of time that elapsed before these treasures reached him, for there is a letter of Bartram's in reply, written in May, 1738, which says:

"Indeed, I was more than two weeks time in gathering the small acrons of the Willow-leaved Oak, which are very scarce, and falling with the leaves, - so that daily I had to rake up the leaves and shake the acorns out, before they were devoured by the squirrels and hogs; and I reckoned it good luck if I could gather twenty under one tree-and hardly one in twenty bore any." 
A few miles distant from Bartram's Garden, in the old village of Darby, now within the boundaries of Philadelphia, lies the Bartram farm where in 1699, the future botanist was born, the son of an English Quaker who had followed the fortunes of William Penn to the New World. Near the spot was a great oak, in later days rated as the largest oak in the State, and estimated at the time of its downfall in 1910, to be seven hundred years old. It was reported as an unusual tree by the University of Pennsylvania and various Forestry Associations. After the old oak had fallen, it was found to be made up of two trees grown together.

Its historic value lies in the appropriate association "of the first oak of Pennsylvania with the first botanist of that State and of America."

\section{Corner Oaks}

At the foot of Marlin's Mountain, Marlinton, W: Va., a cluster of old trees known as "Corner Oaks" have long been associated with the memory of General Andrew Lewis, the hero of Point Pleasant. General Lewis volunteered his services in the expedition to take possession of the Ohio country in $\mathbf{1 7 5 4}$.

At the battle of Point Pleasant, at the mouth of the Great Kanawha River, he acted as Commander in Chief of the American troops, and gained a signal victory over the Indians of the Shawnee Confederacy under the celebrated Chief Cornstalk. This battle was noted as being the most severe conflict with the red men up to that time. General Lewis was also Washington's military trainer, and the latter endeavored to have him appointed Commander-in-Chief of the Armies of the Revolution.

Corner Oaks bear the following inscription:

"General Andrew Lewis, Oct. 6, 1751.

\section{“STRUCK-BY-The-ReE's Tree}

At Yankton, S. D., stood until a few years ago, an oak known to the first settlers there as "Struck-by-the-Ree's Tree." Beside commemorating a savage encounter between the Sioux and the Ree Indians, it had also been used by the former tribe as a burial tree.

The Sioux Chief who bore the title "Struck-by-the-Ree," was born in the late summer of 1804, at the time when Lewis and Clark, captains of the famous expedition to explore the far west, were encamped on Green Island, in the Missouri River, near the present site of Yankton. The Yankton tribe of the Sioux Indians met with them there, and together they held "a grand council, powwow and carousal."

One day, Captain Lewis heard that a papoose had just been born in one of the Indian lodges. Sending for the child he wrapped him in the American flag, prophesying that the boy would become a leader of his people, and a good friend of the white men. His prediction was fulfilled, for Struck-by-the-Ree not only bẹcame a chief of his tribe, 
but proud of having been wrapped in the flag at birth, always ranked himself as a partisan of the white men, and saved many of them from torture or death in the Yankton massacre of 1863.

Struck-by-the-Ree, grown to young manhood, fell deeply in love with a beautiful Indian girl. Together they often sat beneath the oak, talking happily of their future, when one day the terrible warwhoop of the Rees was heard, and a fierce battle followed. It was during this encounter that the young warrior received the wound that earned for him his odd title, though not until after he had suffered a greater misfortune.

\author{
"A youthful form was seen \\ To hover at his side \\ Wherever in the dawn \\ The Chief could be descried. \\ Our warrior's horse was killed \\ At breaking of the day. \\ On foot he fought, the youth \\ But one arm's length away. \\ When from a thicket near \\ An arrow-fiendish dart- \\ Was sent from sinew string \\ Straight at my lover's heart. \\ The youth like lightning sprang \\ From beneath a bending tree, \\ Receiving deep in the breast \\ The arrow of the Ree. \\ Thou hast saved my life, brave youth \\ Thy breast hath been my shield; \\ The Sioux are saved a Chlef \\ Upon this bloody field. \\ Thy name!-Speak quickly!-Alas! \\ My Love! O maiden mine! \\ The arrow for my heart \\ Hath entered into thine!"
}

There was only time to carry the dying girl away from the field, and return, himself, to the battle where he was soon severely wounded by another dart from the Rees. But summoning all his strength he led the charge again, while the word passed from one to another that he was risen from the dead. An overwhelming victory for the Sioux was the result.

Struck-by-the-Ree recovered from his wound, and lived for a number of years, returning often to the old oak, to sit under its shade and mourn his lost love.

\title{
WASHINGTON OAK
}

During the summer of 1791, Washington traveled extensively through the south, and was one morning entertained at breakfast by a lady, who lived in the suburbs of Charleston, S. C. Chancing to hear her order the gardener to cut down a splendid oak because it obstructed the view from the new portico, he interceded for the tree, which was spared at his request and which has ever since borne his name.

From poem "The Old Oak Tree," by Benjamin Wade Borleigh. 
A stalwart oak at Chesterfield, S. C., described as unchanged since 1852, bore its part in the Civil War. To its branches was fastened the first flag bearing the words "Immediate Separate State Action." There the flag fluttered in the breeze until General Sherman arrived on the scene, and burned the jail and courthouse. The tree had long been a favorite resting place for Indians, whose pipes and arrowheads were found beneath it.

\section{Council Oak of the Santa Fe" Trail}

This old tree is one of the few that remain, of the original Council Grove, on the Neosho River, Kan., which was "the largest body of timber between the Missouri River and the Rocky Mountains, and the most noted camping and gathering place on the old Santa Fé trail."

This famous trail was the "early highway over which the commerce of the Plains was carried on for more than a generation before the whistle of a locomotive had broken the stillness of the prairies." It was first used by white traders in 1822 , when a caravan started from Boonville, Mo., and passing through Lexington, Independence and Westport (now Kansas City), traveled south across the State of Kansas and on to Santa Fé, N. M., over seven hundred and seventyfive miles of forest and prairies infested by Indians.

Two years later, in 1824, trade with Santa Fé had increased to such an extent that the United States Government began to show an active interest in carrying it forward. The regular route along the Trail began at Franklin, Mo., and entered Kansas through Johnson County. This portion of it terminated at Council Grove, where it was the custom to halt and reorganize the caravans so that several might proceed together, finding safety in numbers. From the Grove, the Trail continued southwest, reaching the Arkansas River at the Great Bend, following the river to Cimarron, and crossing near old Fort Dodge and the present site of Dodge City, Kan. Here it divided, one branch leading to New Mexico, and the other joining it after following a different road. The Atchison, Topeka and Santa Fé Railway follows the Trail over part of its route.

"There is a wonderful amount of history and romance all along the Old Santa Fé Trail," says J. R. Mead, a member of the Trail Marking Commission for the State Historical Society of Kansas. "Enough to make volumes of absorbing interest. The trail is lined with unknown, unmarked graves. From Cow Creek, west to the State line, every mile has its history of battle attack, ambush, stampede, burned wagons, murdered or captured emigrants, all kinds of killings and escapes. Nearly every General of note in our Civil War, sometime in his career passed over the Trail-Sherman, Sheridan, Harvey, Hancock, Kearney, Miles, Crook, Sumner, Col. Leaven- 
worth, Kit Carson, and Col. Bent. General Fremont traveled the Trail from the Great Bend to the mountains."

In early days, the Trail was the connecting link between east and west. The only teams seen on it were the six yoke of oxen, attached to a wagon carrying from six thousand to seven thousand pounds of freight, and the four or five span of mules drawing a similar wagon, the number of mules varying according to their size.

On August 10, 1825, representatives of the United States Government met with Chiefs of the Great and Little Osage Indians, in the old oak grove, near the Neosho River, to arrange for right of way across the Plains on the Santa Fé Trail. About $\$ 800.00$ in gold was paid to the Indians for this privilege. A week later, a similar treaty was made with the Kansa Indians, near the present town of McPherson, Kan. On the 82nd Anniversary of the treaty made in Council Grove, (Aug. 10, 1907), a granite marker commemorating the event, was dedicated. It was placed in the Grove, about forty feet distant from the famous Council Oak, and is one of the finest of the many monuments on the Trail.

The following verses are quoted from Senator George P. Morehouse's poem entitled "The Council Oak."

\footnotetext{
"Yes, eight hundred in gold was the price that it cost, Yet how small such a sum seems today;

For the tribe by that act such a rich region lost,

When it passed under whites' ruling sway.

But the chiefs of the Great and the Little Osage,

When they counted the gold on that day,

Were so filled with delight, that 'twould take quite a page

To relate what they all had to say.
}

Let us never forget, to the praise of this tribe,

That they never had war with the whites;

But were loyal and true and would scorn ev'ry bribe,

Yet they stood for their just bargained rights.

And they never forgot the "Old Councll Oak"

Or the treaty they made on that day;

For, to them, it was law and no wise a shrewd joke,

This great Trail to the far Santa Fé.

What a noble old tree is this sturdy tall oak, What a tale to relate could it speak!

Of the camps and the fires, with their blue curling smoke,

Which ascend from the wigwam's peak,

Of the storms and the blasts, of the heat and the cold,

of the going and coming of men;

Let it stand for a record of days that are old

And much plainer than words from my pen." 


\section{CHAPTER IV}

\section{A Poplar and the Kensington Rune Stone-The Liberty Tree of Annapolis-The Balmville Tree-Lone Tree.}

\section{A Poplar and the Kensington Rune Stone}

A poplar tree on Mr. Olaf Ohman's farm near Kensington, Minn., has become known to fame by reason of the long hidden treasure discovered beneath it.

On November 8, 1898, Mr. Ohman was clearing a piece of land for ploughing, when his men unearthed from the foot of the poplar a heavy slab of stone weighing about two hundred and thirty pounds. On it was an inscription in runes or character used in secret writing so much in vogue in early times.

Being translated it reads as follows: "Eight Goths (Swedes) and twenty-two Norwegians upon a journey of discovery from Vinland westward. We had a camp by two skerries one days journey north from this stone. We were out fishing one day. When we returned home we found ten men red with blood and dead. A. V. M. (Ave, Virgo Maria) save us from evil. (We) have ten men by the sea to look after our vessel fourteen (doubtfully forty-one) days' journey from this island. Year 1362."

The stone was exhibited, for a while in a drug-store in Kensington, Minn., and was also submitted to two college professors, both of whom pronounced the inscription fraudulent. Then it was returned to its owner, in 1899 and lay in his yard where it was carelessly used as a stepping-stone near his granary for eight years.

In 1907, Mr. Hjalmar Rued Holand obtained the stone and exhibited it in the Middle West, and also at the Norman Millennial Celebration at Ruen, France, in 1911. He brought it to the attention of the Minnesota Historical Society which directed the Museum Committee to make an exhaustive investigation of the authenticity of the inscription. Their researches are published in full, in the Minnesota Historical Society Collections, Volume 15. They are in part as follows:

"The party started from Vinland, a very remarkable statement, in the light of the fact that it is not know, even at this day that a permanent or even temporary colony was established in Vinland. . . . In the light of the results of Professor Fernald's studies on the 'Plants of Wineland the Good,' it is remarkable, if the stone is fraudulent, that the location of Vinland by the statements of the record, should agree with the location of that country by Fernald, since all modern (and even earlier) descriptions of Vinland have placed Vinland either in Nova Scotia or Massachusetts. Could it have been a random and accidental coincidence that a fraudulent record should correct the 
current historical belief of the times? How could an impostor come to the knowledge that Vinland was nowhere except in Labrador, or at least in the region about the entrance to Hudson Strait? ... This agreement with the latest research as to the location of Vinland is a very suggestive fact."

Fourteen days journey from "the sea," if the region of Hudson Bay is indicated, would have brought the foreigners, with the means of travel at their command, to the neighborhood where the stone was discovered and the Bay would have been the nearest port. It is stated that their most probable route would have been from Vinland to Hudson Bay, and to Lake Winnipeg via Nelson River, and up the Red River of the North to the region where the stone was found buried.

Professor Fossom and Mr. Holand searched around Lake Christina and Pelican, as well as other lakes twenty miles north of the stone trying to locate the "two skerries" or rocks surrounded by water. Finally, they found two immense boulders, one of granite, the other gneiss; though not in water now, they are on a point exposed to destruction by ice and waves, and as the lake level is known to have been higher five or six hundred years ago, the rocks answer the description perfectly. The gradual drying up of the region through the intervening centuries, is an established fact. The stone is described as being on an island, though the ground where it was found is not one today. As the historian remarks, it is a remarkable fact that these two skerries exist, and at the right distance from the site of the stone, and that there are no others. In modern times, they could not be called skerries, there being no water around them.

The exact description of the location of the camp is no doubt due to the wish for accuracy as to the burial place of the victims of the massacre, which was probably the work of native savages. And as the practice of scalping was unquestionable strange to the Scandinavians, they were all the more impressed by the horrible sight, speaking of their comrades as "red with blood and dead."

"A. V. M." stands, of course, for a Roman Catholic expression, which according to Archboship Ireland, no modern Scandinavian would use, that nation now being Lutheran. But as it was constantly employed in the 14th century, in time of the plague or "black death" its use in the inscription, when danger seemed to threaten, is another point in favor of antiquity.

It was objected, by some scholars, that certain words used in the record are too modern; others, however, differed from this opinion. At length, finding the mass of evidence to point strongly to the genuineness of the contested statement, the Minnesota Historical Society made the following announcement: "After carefully considering all the opposing arguments, the Museum Committee of this Society, and Mr. Holand, owner of the stone, believe its inscription is a true historic record." 
Which conclusion exonerated Mr. Ohman from the accusation made against him of having cut the inscription; and further proof of his innocence was furnished by the sentinel poplar itself, its roots being wrapped securely about the stone till they were flattened by contact with it. Investigation showed that they had been in this condition without interference, during the tree's entire lifetime-from thirty to fifty years - or before his ownership of the farm.

\section{The Liberty Tree of Annapolis}

On the campus of St. John's College, in the quaint town of Annapolis, Md., stands a huge poplar long known as the Liberty Tree, and entitled to fame both on account of its great age and size, and because of the historic ground on which it grows.

Two feet above ground level, it measures twenty-nine feet, four inches in circumference, and its height is one hundred and fifty feet.

Tradition tells us that in 1652, a treaty was made under the Liberty Tree, between the whites and the Susquehannock Indians. A century later, when problems caused by conditions leading up to the war of the Revolution were under discussion, patriotic meetings were held in its shade, probably earning for the old tree its honorable title. Later still, General Lafayette was entertained beneath its shade, when he visited Annapolis, in 1824.

The College in front of which the Liberty Tree stands, was formerly King William's School, founded in 1694, "for the propagation of the Gospel, and the education of youth in letters and good manners." In 1784, the school was merged into St. John's College, whose central and oldest building, McDowell Hall, was begun in 1745.

In the rear, Rochambeau's army camped, en route to Yorktown to reinforce Washington's troops.

Not only does the Liberty Tree commemorate the time honored events of its vicinity, but its personal history is worth recording. As years passed, it began to show signs of decay, and was supposed to be dying. In 1840, some mischievous boys, playing with gunpowder, placed two pounds in the hollow trunk, and set fire to them. The tree caught easily, and was soon in flames which were extinguished by the citizens who, no doubt, supposed it fatally injured!

The prank, however, proved a blessing in disguise, for the blaze destroyed the worms which were feeding upon its tissues, and the following year it burst into leaf, hale and hearty, none the worse for its adventure.

But in 1907, the aged poplar again required attention, having become so hollowed by decay that eight or ten persons could stand in the interior. The cavity was filled with over fifty tons of concrete and the branches were strengthened with iron rods, and thus a much loved and venerated landmark has been preserved for a long and prosperous future. So successful has the treatment proved that the 
tree has withstood a number of severe storms, and every spring it breaks into leaf with renewed vigor.

It bears the following inscription: "This tablet placed upon the Liberty Tree by the Peggy Stewart Tea Party Chapter Daughters of the American Revolution, of Annapolis, Maryland, October 19, 1907, to commemorate the first treaty made here with the Susquehannocks in 1652, and that George Washington in 1791, and General Lafayette in 1824, visited St. John's College. Through the munificence of James T. Woodward, of New York City, this tree, estimated to be over six hundred years old, has been preserved from decay."

\section{The Balmville Tree}

A short trolley-ride northward from Newburgh-on-the-Hudson, $\mathbf{N}$. Y., carries one to the village of Balmville, named after the old balsam poplar, of immense size, that stands in the centre of the little town. The surrounding country is as full of historic associations as of natural beauty.

During the Revolution, the town of Newburgh, where Washington occupied headquarters, and Balmville, situated on a much traveled route known as the King's Highway, were frequented by the American troops. The huge poplar or Balm of Gilead Tree,-so-called on account of the gum secreted by the leaf-buds and young shoots, and supposed to possess healing properties-stood on the Highway. John Cosman, who before the Revolution was apprenticed to a blacksmith in the neighborhood, is quoted as stating that he often shod horses under the tree which even then was good sized.

But little is known of its early history. According to one account it grew from a riding-switch that was stuck in the ground; it is also said to have been brought as a small branch, broken from a tree in the mountains of New Jersey. Another tradition says that it sprang up, naturally, in the place where it now stands.

Whatever may be the truth concerning the origin of the huge tree, however, it is noteworthy both by reason of its probable usefulness to the travelers of early days, and also its remarkable proportions, the diameter of a poplar ordinarily averaging about seven feet. The Balmville Tree has been measured several times, and the results recorded. In Rutenber's History of Orange County and Newburgh, it is said that a Mr. James Donnelly who first saw the tree about 1782, stated that it was then six or eight inches around, with a spreading top. In 1832, the trunk was measured by a Mr. Williams, who found that at two feet above the ground, its diameter was fifteen feet, two inches; in 1868, it had increased to nineteen feet, five inches. Today it has reached a circumference of twenty-one feet, eight inches, at two feet above ground level, indicating that it may be much older than is estimated. 
On the north bank of the Platte River, about three miles southwest of the site of Central City, Neb., stood for many years a solitary cottonwood known as Lone Tree. Named by the Indians, their chiefs are said to have held their councils beneath its spreading shade, long before the first white settler had reached the spot.

Fifty feet tall, Lone Tree could be seen for twenty miles across the Platte valley, and standing only a few yards from the overland trail north of the Platte River, it was a favorite rendezvous for the many travelers who camped nearby in early days, and cut their names on its bark, until its massive trunk was covered with these hieroglyphics to the height of thirty feet.

Lone Tree ranch, established in the neighborhood, in 1858, was christened in honor of the old tree, and so were the postoffice and railway station three miles distant from it.

In 1865 , the big cottonwood fell victim to the violence of a heavy storm, and a portion of its trunk was preserved at Lone Tree station, (now Central City) as a souvenir of the historic tree that had been loved by thousands of pioneers in the West. It stood on the station platform until all the wood had been chipped off and carried away by tourists.

In 1911, a stone monument in the form of a cottonwood stump was erected on the spot where Lone Tree grew. "There it stands today," says A. E. Sheldon, author of "History and Stories of Nebraska," "in perpetual witness to the worth of a tree." 



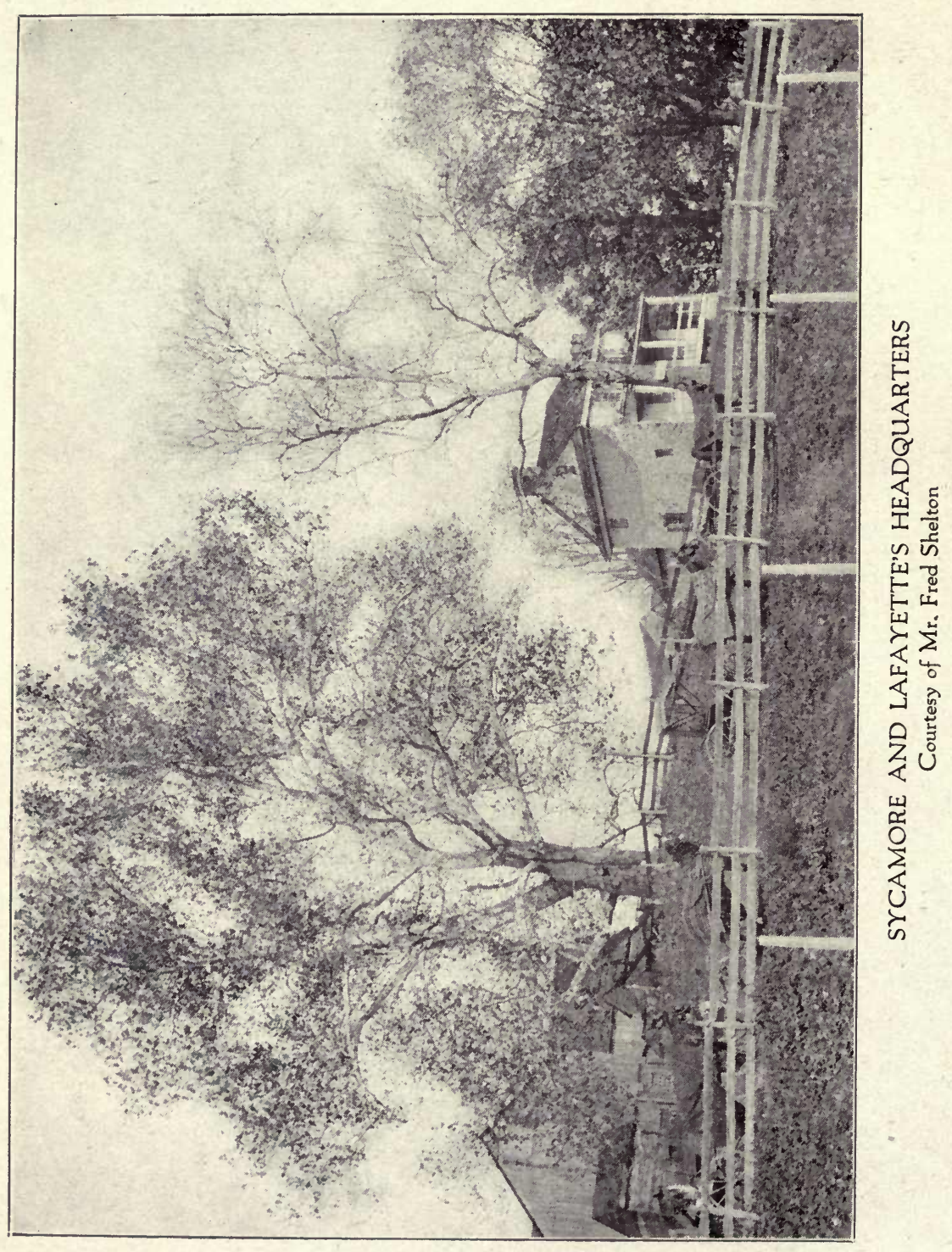




\section{CHAPTER V}

The Treaty Tree of Indian Springs-The Geneva Century Tree-The Pueblo Cottonwood-The Vaulting-Pole Cottonwood-The Rhode Island Sycamore-The Charlemont Buttonwood-The Pringle Sycamore-Lafayette Sycamore-Princeton Sycamores-Sycamores of Camp Frelinghuysen-John Goodway Sycamore-A Sycamore That Orons Itself.

\section{The Treaty Tree of Indian Springs}

Near Indian Springs, Ga., stands a poplar said to be the largest tree of its kind in the State, its trunk measuring twelve feet in circumference nearly one hundred feet upward from the ground level. It is known as the Treaty Tree of Indian Springs, and is a fitting monument to two famous treaties made in its immediate neighborhood between the United States and the red men.

Troubles between the whites and the Indians had marred the closing years of the 18th century, perhaps due to the increasing demands for lands owned by the latter. In 1802, Georgia ceded to the Federal Government all of her territory west of the Chattahoochee, for the sum of $\$ 1,250,000.00$, with the agreement that all Indian titles within her borders were to be peaceably obliterated.

This promise was not kept, however, and in 1823, two prominent men, Campbell and Meriwether, for both of whom counties were afterward named, were sent to treat with the Creek Nation, which held a large tract between the Flint and Chattahoochee. The Upper Creeks, as they were called, lived in Alabama; the Lower Creeks in Georgia, headed by General William McIntosh, whose father was a Scotchman, and his mother an Indian woman.

The conference was not a peaceful one; the Upper Creeks refused any cession of land to the whites, but the lower Creeks, consenting, met them at Indian Springs, on February 12, 1825, and signed a treaty, promising to move west, not later than September 1, 1826. They were to be paid $\$ 4,000.00$, and acres of land equal to what they relinquished.

Angry at the loss of their lands, however, the hostile Creeks planned and executed one of the most tragic reprisals in the history. of our country.

General McIntosh was the victim, on account of his having played such a prominent part in the transaction. One hundred and seventy Indians concealed themselves in the woods close by his house on the bank of the Chattahooche River, near the modern town of Carrollton.

Just before daybreak, on May 1, 1825, they set fire to the building. McIntosh and the friend who was with him, treated the savages 
to a volley of shots from behind their barricade, but the door was quickly battered in, and the brave chief who had more than once served his country well, died a fearful death at the hands of his enemies.

Later, the treaty of 1825 was repudiated by Congress, and a new one drawn up, altering the boundaries of Georgia. The State's survey of the newly acquired land was ordered stopped, by President Adams, doubtless at the instigation of the discontented chiefs, who had gone unpunished for the murder of McIntosh and their white friends.

But Governor Troup, of Georgia, General McIntosh's cousin, and a vigorous upholder of State sovereignty, stoutly refused to recognize the changes, and continued the survey of the land which he had begun by order of the State. He sent the following message to Congress: "We might constitutionally have appealed to you for defense against invasion, but you yourselves are the invaders; and, what is more, the unblushing allies of savages whose cause you have adopted." Finally, due to his firm stand, the matter was adjusted peaceably.

The old Treaty Tree recalls a stirring chapter, indeed, in American history, and has been commemorated in verse by Lucien Lamar Knight, State Historian of Georgia.

\footnotetext{
"By the water's crystal margin, On whose bosom, dreamily,

Falls the shadow of the forest, Stands a proud, imperial tree.

No companion rises near it; No congenial shade is nigh;

Rivaled only by the mountains, Piled against the purple sky.

"Fit memorial of the Red ManIts majestic silence speaks,

Of a time when all these valleys Held the wigwams of the Creeks.

Ere their fair domain was ceded, At the white man's stern behest,

Or the sunset's beckoning splendors, Wooed them to the Golden West.

"Like a tall Corinthian column, Reared beneath a summer cloud,

Part of God's own grand pavilon, Verdue-paved and azure-browed;

Reaching from the world below it, From its sorrow-stricken sod,

To the golden lamps above itTo the sweeter airs of God."
}

\section{The Lafayette or Geneva Century Tree}

On June 8, 1825, General Lafayette was entertained at Geneva, N. Y., while touring that State, and was received by an enthusiastic gathering, under the tree which still bears his name. The Lafayette or Geneva Century Tree, as it has also been called, is an immense balsam poplar, standing on Maple Hill, on the corner of the Albany and Buffalo turnpike and the old Pre-emption Road. This highway was once an Indian trail, but became a State road in 1794. 
The branches of the south half of the tree shade the whole width of the street, and religious services have been held under them, accommodating quite a congregation. One hundred and twenty feet in height, it boasts a circumference of twenty-four feet, and the diameter of its foliage measures one hundred and fifteen feet.

The great poplar claims an interesting history. Over a century ago, when Geneva was a tiny settlement, Ephraim Lee, a free trader, traveled from Albany to Buffalo by this road. He cut a sapling for a walking-stick, but overcome with weariness, lay down for a nap under the maple trees on the hill, sticking his cane in the ground for safe-keeping. When he awoke and found the lateness of the hour, he hurried forward on his journey, forgetting the sapling. Passing it on his trip, the year following, he was surprised to see that it was growing and in leaf.

There it continued to flourish, being spared because of its odd history, after the maples were cut down. In 1843, the roadmaster insisted that the tree must be destroyed. The resourceful owner, however, wasted no time in parleying, but hammered spikes into its trunk from the ground upward, encasing it in a coat of mail which no axe could penetrate. Tree experts have been reported as believing that the iron has been a great factor in the poplar's age and vigor.

\section{The Pueblo Cottonwood}

A huge poplar or cottonwood at Pueblo, Colo., shaded the burial spot of the first white woman who died within the boundaries of that State. Beneath its branches, thirty-six white persons were massacred by savages and fourteen men were hung from the old tree's branches. When the cottonwood was felled in $\mathbf{1 8 8 3}$, its age was considered to be three hundred and eighty years. A cross section of its trunk was placed on exhibition in Mineral Palace, Pueblo.

\section{Vaulting-Pole Cottonwood}

In the spring of 1815 , two boys, Hosea Pierce and a companion, returned to their homes near Norris City, Ill.; after serving in the War of 1912. Both boys had helped General Jackson to rout the British at the Battle of New Orleans. During the spring, both attended a log-rolling on the Pierce farm, and on their way home, used their cottonwood handspikes as vaulting-poles, making a wager which could vault the further. They left the handspikes sticking in the earth, and both poles took root, and developed into fine trees. One lived till about 1910, the other is still standing at one hundred and five years of age. It is an immense tree, thirty feet in circumference, and one hundred and seventy-five feet high. The hollow base of its trunk is used to shelter setting hens, or as a kennel. It is to be regretted that no effort is made to preserve this interesting old poplar. 


\section{The Rhode Island Sycamore}

One disastrous result of the British occupation of Rhode Island from 1776 to 1779 , was the ruthless destruction of its forests, specially along the coast region. During the severe winter of 1780 , when many refugees from the State returned to their homes, wood was so scarce that in Newport it sold at $\$ 20.00$ a cord.

One ancient sycamore remained, however, mysteriously spared to mourn its departed comrades. It stood on the estate of Thomas $\mathbf{R}$. Hazard, between the house and the Seaconnet or Eastern Channel. A few years before the old tree fell in 1869, its trunk measured thirtytwo feet in circumference at twelve inches from the ground. Its upper portion destroyed by wind and storm, it has been described as "the picture of a desolated Anak of the woods."

Probably numbering its years at several centuries, the Rhode Island Sycamore may have witnessed stirring events unrecorded in American history, as well as the tragic days of the Revolution. One daring episode that transpired nearby, just below Vaucluse, was the capture of Pigot, the floating battery, equipped with twelve eightpounders and ten swivels, which the British were using to block the Channel. Captain Silas Talbot undertook its removal; arming the Hawk, a coasting schooner, with sixty-eight men he sailed down under cover of a dark night, secured his prisoners by fastening cables over the hatchway, and carried his prize off to Stonington.

\section{The Charlemont Buttonwood}

Another historic sycamore or buttonwood stands in the town of Charlemont, Mass., near the Deerfield River. It is a noble shade tree, ninety-eight feet in height, while its branches cast their shadow over a radius of eighty-five feet. Under them passes one of the ancient highways of the Indians, the "Mohawk Trail."

Captain Moses Rice, the first pioneer settler of the place, has left the record, handed down from one member of his family to another, that "he had slept under the Buttonwood tree when there was not another white person in town."

$\mathrm{He}$ had come to a region that was hostile to strangers, though for a while the household was unmolested, and was a centre of hospitality for travelers. But in 1746, Captain Rice and his family were forced to escape to Rutland in order to save their scalps from the savages. Three years later he returned to find the house destroyed, and unluckily for himself, rebuilt it.

He was ploughing, in company with his son, grandson, and two friends on the morning of June 11, 1755, when a party of six Indians, who were hidden among the trees, waiting the moment most favorable to an attack, fired and surrounded them. Captain Rice was badly wounded, and after a sharp struggle, was scalped and left bleeding, while his companions were either killed or made prisoners. A few hours later he died at his son's house. 



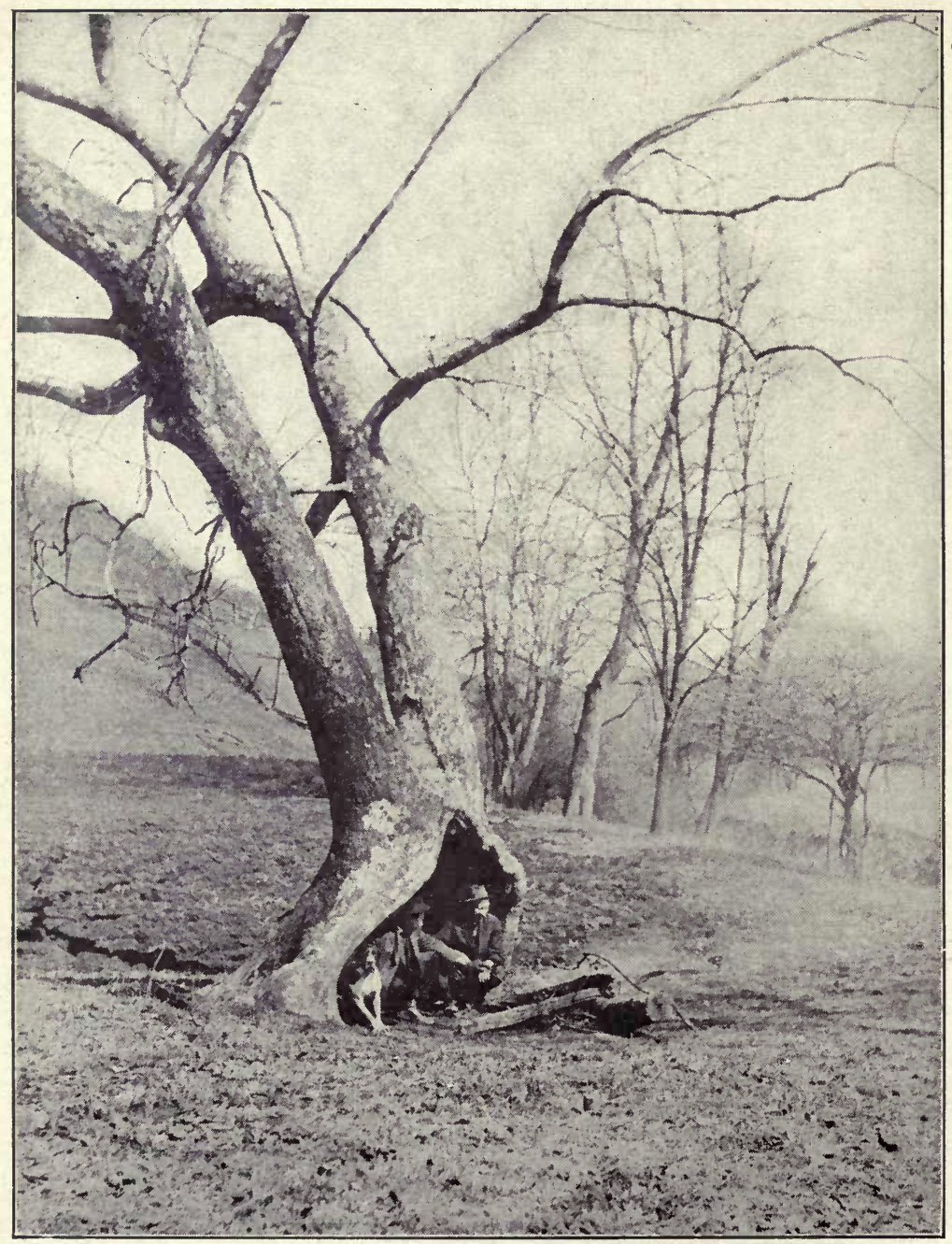

THE PRINGLE SYCAMORE'S DESCENDANT

Courtesy of Mr. J. C. Mc Whorter 
On the hillside, in sight of the old Buttonwood, venerable headstones, on some of which the inscriptions are nearly obliterated, mark the graves of himself and his family, and Phineas Arms, another victim of the same massacre.

\section{The Pringle Sycamore}

A tree that for many years recalled to memory the earliest white settlers of West Virginia, was the famous Pringle Sycamore, which stood about three miles north of the present city of Buckhannon in that State, at the mouth of a stream known as Turkey Run.

The two brothers, Samuel and John Pringle, deserted from the British forces at Fort Pitt, in 1761. Their chief concern being how to escape arrest, they camped with two comrades, first in the wild country about the Monongahela River, then near the borders of the Youghioghney. In 1762, they arrived at a settlement in Looney Creek, but there two of the party were arrested. The Pringles, fortunate enough to get away, continued their travels, finally reaching the Buckhannon River, and finding, on its bank the old sycamore in whose hollow trunk they proceeded to make their home. The cavity measured eleven feet, inside, and in this palatial retreat the fugitives lived for over two years until the late of autumn of 1767 .

Then they faced starvation, only two charges of powder remaining. John journeyed back, across the mountains in search of more ammunition, and learned that peace had been made with the French and Indians. No longer fearing arrest, the two brothers left the old tree which had sheltered them in such friendly fashion, and returned to their former haunts on the Wappatomaka River, the south branch of the Potomac.

In the fall of 1768, Samuel led a party of colonists back to the banks of the Buckhannon, where, the next spring they cleared land, planted and built their cabins. The first crops were destroyed by buffalos, and it was not till $\mathbf{1 7 7 0}$ that the pioneer settlement was really established. One of their number was Jesse Hughes, who became a renowned scout and Indian fighter.

It is an interesting fact that a man named William Pringle, living in Philadelphia, was the father of two sons named John and Samuel, born in $\mathbf{1 7 2 8}$ and 1731. It is quite possible that the two boys were the future tenants of the hollow sycamore.

The old tree fell about a century ago, but the stump remained as late as 1848. It disappeared, but a second tree sprang up from its roots, and flourished till a flood carried it away in 1880 .

But there was still life and enterprise in the roots of the Pringle Sycamore. "As if reluctant to fail to mark the site of the first primitive home of the white man in that region," says L. V. McWhorter, the historian, "the roots shot forth a second sprout and this grew into a bushy tree." And by a singular coincidence- "It has a cavity 
in its trunk that will shelter two or three men from an ordinary storm."

Mr. Webster Dix, the owner of the sycamore, has promised that it shall be carefully preserved.

\section{The Lafayette Sycamore}

Among the historic landmarks connected with the Battle of the Brandywine, visitors to the region are shown the house, on Baltimore Pike, in Birmingham township, Delaware County, Penn., which General Lafayette occupied as his headquarters, just before the battle, or early in September, 1777.

Close by the house stands a fine old sycamore, measuring twentytwo feet in circumference at a short distance above ground level, still healthy and vigorous, a living memorial of the brave but unequal struggle, when Washington with 11,000 men attempted to check Howe's advance to Philadelphia with nearly double that number.

At the close of the day, Washington retired to Chester, and (so the story runs), Lafayette, badly wounded in the leg, stood at the old Third Street bridge in that town, endeavoring to rally the retreating troops. It is said that he was carried back to headquarters, and laid under the old sycamore; but it is also stated and probably on good authority, that he never returned there, but was cared for in Chester. And in that town three places contend for the honor of having been the spot where his wounds were treated!

\section{The Princeton Sycamores}

In 1765, the year preceding the Stamp Act Repeal, an order was given to plant a number of sycamores in front of the residence of the President of the College at Princeton, N. J. It is possible that the order was not carried out till the following year, and perhaps for this reason these trees have always been associated with the Stamp Act. Two of them are still standing, on Nassau Street, the old house being now occupied by the Dean. They are splendid specimens, about ninety feet tall, and three feet in diameter at six feet above the ground.

\section{Sycamores of Camp Frelinghuysen}

Other sycamores, in Newark, N. J., lay claim to historic interest as belonging to "Camp Frelinghuysen," the drill ground for New Jersey Volunteers, 1862-1865. Men who trained here gave their lives on every battlefield from Antietam to Appomattox. "One of the trees is known as the Colonial Plane, and is honored as a tree under which Washington and his army passed, in 1776. Another, the Academy Plane, witnessed the burning of the First Academy, in 1780, when a party of British soldiers crossed the frozen river from New York, and took the town by surprise. 


\section{The John Goodway Sycamore}

Just outside of Linglestown, Dauphin County, Penn., stands a sycamore pronounced by the Department of Forestry to be the largest in the State. The tree is associated with John Goodway; the last of the friendly Indians in the region about Harrisburg and has been left standing as a memorial to him. Its circumference is twenty-five feet and its diameter is over seven feet.

\section{A Sycamore That Owns Itself}

Through the kindness of admiring friends, a large sycamore of Pippapass, Knott County, Ky., has received a gift of land sufficient to protect it from interference as long as it shall live. While the tree's exact age is not known, it must be estimated at many years, the trunk measuring nine feet in circumference at a height of four feet from the ground. It shades a home known as "the house of the sycamore tree," in the Caney Creek Community Centre, and has been christened the "Freed-Budd Tree," probably in compliment to two of its well wishers.

The deed of conveyance filed in Knott County, on August 20, 1918, reads as follows:

"For, and in consideration of its shade, coolness and inspiration, and in value of itself as an æsthetic asset, the parties of the first part hereby convey to the party of the second part in trust for the use and benefit of the said sycamore tree, and to ITSELF as absolute owner, the said tree, and the said terra-firma, the ground upon which it stands, is to belong to ITSELF, and is hereby conveyed in the same manner as the said tree is conveyed, in consideration of the value of itself, as a resting place for the weary under the shade of said tree, and the said tree and the said terra-firma are to belong to themselves absolutely and to each other for all the purposes which Nature and God intended them, among which is the purpose of the soil to nurture and feed the tree, and that of the tree to shade, grace and beautify the said terrafirma." Thirty-six square feet is the extent of the land owned by the sycamore.

Herein is contained a happy suggestion for all tree-lovers. 


\section{CHAPTER VI}

The Penn Treaty Elm-Descendants of the Penn Treaty Elm.

\section{The Penn Treaty Elm}

The Penn Treaty Elm stood at Shackamaxon, on the Delaware, a few miles north of Philadelphia, Penn., and was a tree of noble proportions, measuring twenty-four feet in circumference at its base, and noted as having a branch one hundred and fifty feet long. Under its spreading shade many a council had been held among the chiefs of the various Indian nations, who either lived in the vicinity, or came as guests, and to this custom the place owed its name of Shachamaxon. Originally, as appears in old records, the spelling was Sachamexing or Sachemexing, derived from the word Sakima, a king or chief, (whence our familiar word Sachem), and the Indian termination "ing" which signified "locality or place where," therefore "place where chiefs resort."

Naturally enough, it has been thought that the old elm was also the meeting-place of the chiefs and Mr. Markham, William Penn's cousin, who preceded him to the New World, as his representative; and also the three commissioners, sent by the Proprietor to assist in looking after his affairs. They brought with them the following instructions:

"Be tender of offending the Indians. Let them know that you are come to sit lovingly among them. Let my letter and conditions with my purchasers about just dealing with them be read in their own tongue, that they may see we have their good in our eye, equal with our own interest; and after reading my letter and the said conditions, then present their kings with what I send them, and make a friendship and league with them according to those conditions, which carefully observe, and get them to comply with you; be grave, they love not to be smiled on."

The letter referred to,-William Penn's celebrated letter to the Indians, - is dated October 18, 1681. "I shall shortly come to see you, myself," he writes, "at which time we may more freely and largely confer and discourse on these matters. In the meantime, I have sent my commissioners to treat with you about land and a firm league of peace."

It was to confirm this "league of peace" that William Penn met the chiefs under the treaty tree, in 1682; perhaps also to endorse the protection promised by his commissioners to the Susquehannas, who were annoyed by troubles in their territory. The belief that there was, on this occasion, any transaction concerning the purchase of land by him, is unfounded, as the earliest authentic record of such a purchase by himself is dated June 23, 1683. So deeply rooted was this idea, 


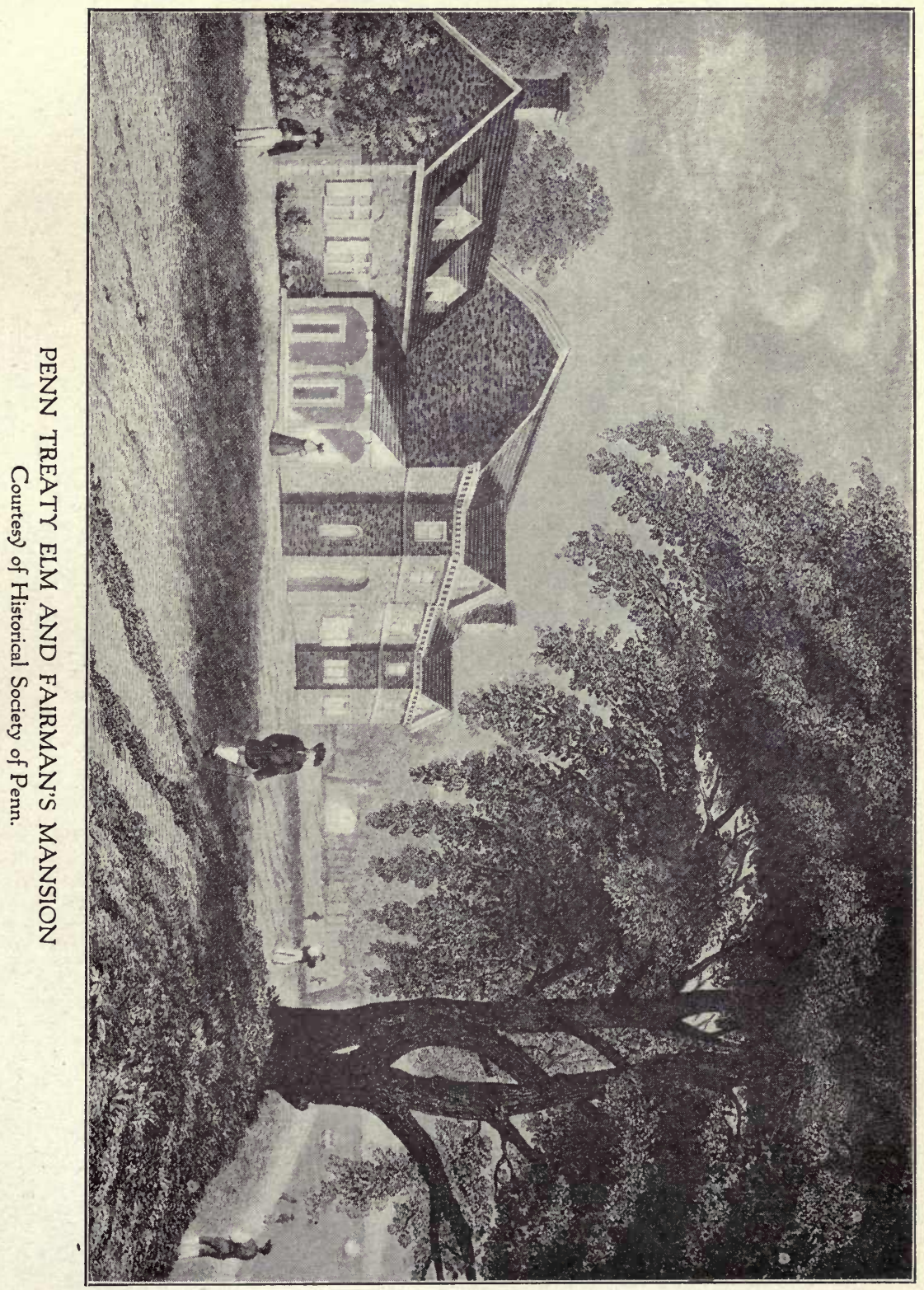



however, that the Historical Society of Pennsylvania commissioned Peter du Ponceau and J. Francis Fisher to investigate the truth concerning the famous treaty, and their report published in 1834, but as too often happens, lying unread in the archives of the Society, sheds much light upon a story which must always be of interest to lovers of history.

It clearly shows that the treaty was simply a guarantee of friendship and good-will, in order that the tribes might be assured of the white mens' desire for peace and fair dealing. Penn's fame should rest not upon the fact of having entered into such an agreement, various other treaties of similar character having previously been made between the whites and Indians, but upon the manner in which he lived up to the spirit of it.

His personal friend, Mr. Oldmixon, who, in 1708, published a book entitled "The British Empire in America," records that the Indians "have been very civil and friendly to the English, who never lost man, woman or child by them, which neither the colony of Maryland nor that of Virginia can say, no more than the great colony of New England. This friendship and civility of the Pennsylvania Indians are imputed to Mr. Penn, the Proprietary's extreme humanity and bounty to them, he having laid out some thousands of pounds to instruct, support and oblige them.

Heckewelder, who wrote a history of the Indians of Pennsylvania and nearby States, says, that the tribes "frequently assembled in the woods, in some spot, as nearly as possible similar to those where they used to meet their brother Miquon," (the Delawares' name for Penn), "and there lay his words or speeches, with those of his successors, on a blanket or clean piece of bark, and with great satisfaction go successively over the whole. This practice, which I have repeatedly witnessed, continued until the year 1780, when the disturbances which then took place put an end to it, probably forever."

Unfortunately, the text of the "Great Treaty" has not been preserved. Governor Gordon, of Pennsylvania, (the same who styled William Penn, "The Father of this Country") referred to it as having been recorded in writing, but as no such record could be found in possession of the Provincial Council at Harrisburg, one or another of the Provincial governors was accused of having carried it away, though there seems to have been no good reason for any such rumor. Our fullest authentic version of its stipulations is contained in Governor Gordon's speech to "Civility" and other Indian Chiefs with whom he met, at Conestogo, in 1728, on the occasion of another treaty. He then referred to the "chief heads" of the Penn Treaty as in substance as follows: that all William Penn's people and the Indians should be brethren, showing each other hospitality; that they should believe no false rumors about each other without ascertaining the truth, but should 'bury them as in a bottomless pit'; that they should promptly acquaint each other of any tidings of danger; that neither 
should harm the other nor his creatures; that where either injured the other, satisfaction should be made and the wrong forgotten; and that both Christians and Indians should acquaint their children with this "league and firm chain of friendship made between them, and that it should always be made stronger and stronger, and be kept bright and clean, without rust or spot, between our children and our children's children, while the creeks and rivers run, and while the sun, moon and stars endure."

Benjamin West, whose painting of the Great Treaty is famous, has left us an interesting account of the loving care with which the old elm was guarded, long years after that occasion.

"This tree," he writes, "to which I well remember, about the year 1755, when a boy, often resorting with my school-fellows, was in some danger during the American War, when the British possessed the country, from parties sent out in search for wood for firing, but the Jate General Simcoe ordered a guard of British soldiers to protect it from the axe."

It spite of precautions, however, the grand old tree did not remain many years longer to serve as a shrine for patriots, but was blown down in 1810, though one cannot help regretting that it did not survive another century.

Judge Peters, a friend of Washington, wrote the following lines in honor of the old elm:

\footnotetext{
"Let each take a relic from that hallowed tree,

Which like Penn, whom it shaded, immortal shall be;

As the pride of our forests, let elms be renowned,

For the justly-prized virtues with which they abound.

Though time has devoted our tree to decay,

The sage lessons it witnessed survive to our day;

May our trustworthy statesmen, when called to the helm,

Ne'er forget the wise treaty held under the elm."
}

\section{Descendants of the Penn Treaty Elm \\ General Oliver's Tree}

When the land where the Treaty Elm had stood, came into the possession of General Paul A. Oliver's ancestors, a shoot was discovered springing up from the old tree's roots. 'This was transplanted to Bay Ridge, N. Y., where it flourished until after fifty years it had almost reached the size of the parent tree. Then the General removed it to his home at Wilkes-Barre, Penn., where it has continued to thrive.

On Arbor Day, April 10, 1896, a shoot from General Oliver's tree was planted on the campus of the University of Pennsylvania, Philadelphia, by Governor Hastings of that State, in honor of William Penn, first Governor of the Commonwealth. The tiny sapling grew into a healthy tree which has rounded out its first quarter century. It is one of the youngest of the Great Elm's descendants.

Another scion of the old tree stands on the grounds of the Pennsylvania Hospital, Philadelphia, and yet another in the yard of the 
Friends' Meeting, in Twelfth Street, in the same city, silent witnesses to the memory of the Great Treaty, which Voltaire described as the only agreement "between the Christians and the Indians that was never sworn to and never broken." 


\title{
CHAPTER VII
}

\begin{abstract}
The Markham Elm-The Wethersfield Elm-A "Great Elm" of West Virginia-The Neenah Council Tree-The Seneca Council TreeThe Elm of Italy Hollow-The Fort Howard Elm-The Franklin Elm-The Kingsport Elm-The Oberlin Elm-The Washington Elm.
\end{abstract}

\section{The Markham Elm}

This great tree, believed to have lived through six centuries, stands on the Markham estate two miles north of Avon, N. Y. It is an elm of the variety known as weeping; that is, its long, graceful branches, used as swings by the boys and girls of pioneer times, once hung in graceful festoons to the ground.

Its trunk measured forty feet around, its height was in proportion, and as its shade covered an acre, the immense elm possessed great beauty. The Indians of $\bar{W}$ estern New York held it in great veneration and made the spot a favorite camping-ground. It also served as a resting-place for the early missionaries, scouts and traders.

William Markham, great-grandfather of the present owner of the estate, is said to have first seen the old elm in 1764, while on a mission to the Seneca Indians. In 1794, his son purchased the farm, which has remained in the possession of the family ever since. More than half a century ago, the old tree was accidentally set on fire, according to one story, by a party of sportsmen; this is related to have occurred during a January thaw, so that the high water surrounding the elm prevented anyone going near enough to extinguish the blaze, which consequently injured the trunk fatally.

Decay set in, and progressed, so that when the Chief of the Division of Forestry, of the Department of Agriculture, at Washington, wished a cross-section of the trunk for exhibition at the World's Fair in Chicago, it was impossible to comply with his request. About this time, part of the trunk caved in, leaving a space through which a span of horses could be driven. In 1893, the north side of the huge tree blew down; this portion was sawed across, and three hundred and seventy-five rings of annual growth were counted. An estimate of the age of the part that had decayed near the centre of the tree, placed its years at six hundred.

Still, the veteran elm had not lost its vitality; in the spring of 1920, after bursting into leaf, and then losing every one through an onslaught of canker worms, it rallied bravely and in a few weeks was once more in full foliage.

\footnotetext{
What tales, if its old trunk could talk, Would fall upon the listening ear,

of the wild wolf upon his walk,

The red-man with his spear.
} 
It towered the giant of the wood,

In a rich robe of emerald drest,

When launched upon the ocean flood, Columbus sought the west.

It braved old winter's rudest shock When the storm-fiends their trumpets blew,

When on stern Plymouth's hallowed rock Landed the May-Flower's crew.

It was the forest's pride, when came The Norsemen, borne grey ocean o'er,

And the Round Tower, long known to fame, Built on New England's shore,

Within its hollow trunk are seen The smoky, blackened marks of fire,

Though in its top of loving green The wind still tunes its lyre.

\section{The Wetherseieid Elm}

A fine old elm in the town of Wethersfield, Conn., is noted both for its great size and its historic associations. It is the only surviving member of a group of elms which figured in the early history of the locality, and were, therefore, landmarks of special interest.

The "wave of enthusiasm for civic beautification" which swept through the towns and villages of Connecticut during the 17th century, is thought to have resulted in the placing of a row of these splendid shade trees down the centre of many a village street, and it is believed that the "Great Elm" as it is called, was planted at that time.

Rising to a height of one hundred and ten feet, its branches spreading one hundred and seventy-five feet, it is considered by many to be the largest tree east of Yellowstone Park. Measurements taken around its roots show a circumference of forty-one feet.

During his tour of the colonies, Charles Wesley preached under the old elm in 1750, making the spot a memorable one in the religious history of the country.

This tree has been more fortunate than many of its contempories in receiving the watchful care necessary to preserve it to attain a great age.

\section{A “Great Elm" of West Virginia}

About sixteen miles north of Clarksburg, W. Va., the birthplace of General Stonewall Jackson, stood, until 1910, another tree bearing the title of "Great Elm." Also famed for its size, it was awarded a prize as the largest of its kind in the United States. At the ground level, including the spread of its roots, it measured forty-two feet in circumference, three feet above the ground, its trunk was twentyseven feet around; one hundred and twenty feet high, its branches reached over a circle of one hundred and forty feet. This tree is commemorated in Mr. Granville Davissen Hall's stirring novel, "The

From poem by W. H. C. Hosmer. 
Daughter of the Elm." This story deals with events that occurred just prior to the Civil War, and relates the doings of a band of robbers that terrorized the surrounding country, using the Great Elm as their rendezvous.

\section{The Neenah Council Tree}

A noted Council Tree or Treaty Elm of immense size, stood until 1890 , on the point of land that juts out into Lake Winnebago from the inlet of Fox River, at Neenah, Wis. Large enough to be seen at a long distance, it served as a guide-post to pilots on the lake. Beneath its branches, the conversation well known in the history of the State, is believed to have occurred, between Four Legs, a Winnebago Chief, and General Henry Leavenworth.

"When General Leavenworth, some years previous to 1827, was ascending the Fox River with troops, on his way to the Mississippi, on arriving at this pass Four Legs came out, dressed in all his gewgaws and feathers, and painted after the most approved fashion, and announced to the General that he could not go through; "the Lake," said he, "is locked."

"Tell him," said the General, rising in his batteau, with a rifle in his hand, "that THIS IS THE KEY, and I shall unlock it and go on."

The chief had a good deal of the better part of valor in his composition, and so he replied, "Very well, tell him he can go."

The site where the old elm stood for so long, like a watchful sentinel guarding its domain, is now part of Riverside Park, at Neenah. A slab of its wood, forming the top of a large table in the historic log cabin of Governor Doty, in the vicinity, is a treasured souvenir of olden times.

\section{The Seneca Council Tree}

The Seneca Indians possessed a noted Council Tree, a great elm, near their village of Kanandesaga, N. Y., the last capital of their nation.

Besides sheltering their conclaves, the old elm marked otherwise historic ground, for Kanandesaga figured in the French and Indian War and the Revolution, and during the former war the English established a fort here, thus securing the friendship and assistance of the warriors. This relationship continued through the Revolution, even though the Seneca Chief, "Big Tree," vowed friendship for Washington and went to visit him.

Later, Kanandesaga was rechristened Geneva, and became the present city of that name in New York State.

\section{The Elm of Italy Hollow}

As a result of the State College of Agriculture's inquiry conducted during 1920, for the purpose of determining which was the 
largest tree in New York State, the "Big Elm" of Italy Hollow, near the border of the towns of Potter and Middlesex, N. Y., carried off the prize.

Old tradition marks this as a favorite Indian Council Tree, and the only member of the primeval forest that escaped the pioneer's axe, in that locality. As its trunk measures thirty-two feet in girth, while it shades an area of eight thousand six hundred and fifty square feet, the splendid old tree is fully entitled to the honor accorded it. Standing at the junction of several Indian trails, it furnished an accessible meeting-place for the various tribes. While the council fires burned, near the Big Elm, scouts stood on vigilant guard against wolves, bears and panthers that frequented the neighborhood.

\section{The Fort Howard Elm}

This elm occupies the site of the first permanent fortification in Wisconsin, and represents two hundred years of the history of the region under the rule, in turn, of France, Great Britain and the United States. The date of the building of the first fort is unknown, but was probably about 1718 .

The history of this post was practically the history of the State during the French regime. Around the fort were waged the Fox Indian Wars. It was also a popular trading post, and was a centre for the dishonest dealing that led to the overthrow of French rule in America.

The British, in 1761, occupied and rebuilt the post, christening it Fort Edward Augustus. After Pontiac's conspiracy in 1763, the garrison was permanently withdrawn and not replaced until after the War of 1812. In August, 1816, the United States occupied this place with a strong garrison, and built the military post named Fort Howard. This was almost continually garrisoned until 1852, when the need for martial protection ceased. The garrison was at that time removed, the land and buildings were sold, and but few reminders are left of the historic importance of Fort Howard, save the old elm tree. This stands just south of where stood the commanding officer's quarters, which were occupied by several men noted in American history. Probably the best known of the American commandants was Major Zachary Taylor, who afterwards became President of the United States.

\section{The Frankin Elim}

New Haven, Conn., known as the "City of Elms," possessed for many years a fine specimen known as the Franklin Elm because it chanced to be set out on April 17, 1790, the day that the great man died. The story of the tree's entry into the town where it has so long been a famous landmark, is rather an unusual one.

Long before the days of Prohibition, Jerry Allen, whose home was at Hamden, a few miles from New Haven, arrived in the latter 
town, carrying the elm on his back. Having no money, with which to purchase his favorite beverage, rum, he traded the young tree in exchange for a pint, to Thaddeus Beecher, who kept a tavern where the Exchange Building of New Haven now stands.

Beecher at once planted the tree on the village green or public square, which had been allowed to remain exactly as it was laid out in 1639. Serving in its early days, and at the time the elm was planted, as a market, public pig-pen, and place for watering cattle, the historic green is, today, in the centre of the busy city, with which the tall, spreading elm has so long been identified.

\section{The Kingsport Elm}

On Kingsport Farms, at Kingsport, Sullivan County, Tenn., is a splendid old elm, with a spring issuing from its roots, in all probability the tree described by a party of Frenchmen who camped in the neighborhood in 1790. It answers their description well, even to the spring that bubbles up beneath it.

Its circumference, which is mentioned as being twenty-two feet, has increased to twenty-five and one-half feet, and its age is estimated at more than 400 years. Directly back of the old elm is the remains of one of the first silk mills in the south, perhaps in the whole country.

\section{The Oberlin Elm}

The elm on the college campus at Oberlin, O., which has been fenced about and marked with a bronze tablet, shaded the first log house built in Oberlin. This was erected in 1833, and was the beginning of Oberlin College, the first educational institution in the world to admit women on an equal footing with men. Lucy Stone, one of the pioneer suffragists, was a graduate of Oberlin.

\section{The Washington}

One of the most famous trees in the whole country is this elm at Cambridge, Mass., under whose "branches Washington took command of the Continental Army on July 3, 1875. It is thought to be a survivor of the primeval forest that once covered the region, and in its youth was nearly 100 feet in height, while the spread of its branches measured 90 feet.

On Nov. 30, 1864, the City Council decreed that "the committee on Public Property cause a suitable tablet of durable material, either granite, marble or iron to be placed on the Washington Elm in Ward 1 , said tablet to commemorate in conspicuous letters the Revolutionary event which rendered said tree historical."

A large branch fell from the elm in 1872, and was used to make a pulpit in a chapel nearby. Since that time, the old tree has gradually succumbed to the attacks of insects and though still standing, has lost much of its original beauty. 



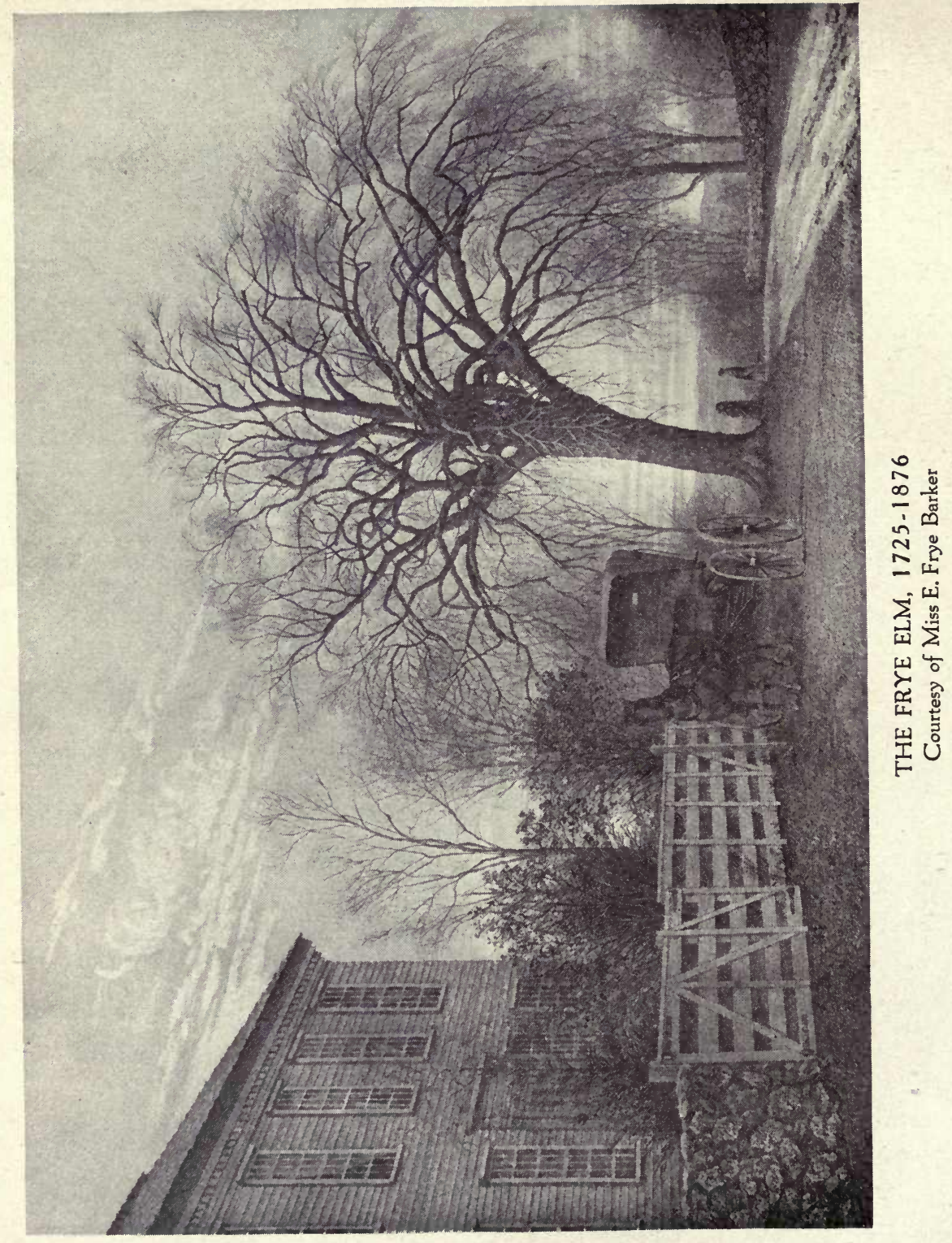




\section{CHAP'TER VIII}

\section{The Frye Elm-The Logan Elm-Old Elm Tree Corner-Elm of the Colony of Transylvania-Daniel Boone's Judgment Tree-Con- stitutional Elm of Indiana-The Morse Elm-The Tappan Elm.}

\section{The Frye Elm}

In 1725, Jonathan Frye, who had graduated from Harvard two years before, left his home in North Andover, Mass., to serve under Captain Lovewell, the famous Indian fighter. The party was bound for the wilds of New Hampshire and Maine, and young Frye went along as chaplain. Before going away, he planted an elm in front of his uncle, Col. James Frye's house at North Andover, charging the family to take good care of it during his absence.

The tree lived to bear, for over one hundred and fifty years, a family name of note, Jonathan being a connection of Elizabeth Frye of England, the great prison reformer. He never returned to see his elm, and his fate was never known, though easily surmised. He received honorable mention in the story of the much famed battle with the Indians at Pequawket, where, with other unfortunates, he was left in the woods, badly wounded. The elm of his planting flourished, and descendants of the Frye family have come from far to visit it.

The only pieces of the old elm known to be still in existence, are a frame containing the original copy of the Frye Coat of Arms, owned by Miss E. Frye Barker, of New York, historian of the family; and the frame of the steel engraving from which the accompanying cut was made. This engraving has been presented by Miss Barker to the New England Historic Genealogical Society.

\section{The Logan Elm}

One of the valued landmarks of Pickaway County, O., is the fine old tree about seven miles from Circleville, known as the Logan Elm. Under its branches the Mingo Chief, whose name it bears, made his famous speech which Thomas Jefferson later incorporated in his "Notes On Virginia," pronouncing it equal to any passage in the writings of Demosthenes or Cicero.

Logan, one of whose names was Tah-gah-jute, meaning "short dress," was also christened in honor of James Logan, Penn's Secretary, who was a great friend of the Indian boy's father, Skikellimus. This chief was always friendly to the white men, entertaining the first Moravian missionaries in the section of Pennsylvania about his home, and conducting many negotiations between James Logan and the native tribes.

Brought up in this peaceable atmosphere, his son followed in his footsteps, earning the title of "Friend of the White Man"; it was 
not till the last years of his life that he became hostile, and then only in revenge for sorrow caused by the murder of his relatives.

He was living in Ohio at the time of "that bloody perlude to the Revolution," the Dunmore War, the purpose of which was to exterminate the Indians of that region. The noted Chief, Cornstalk, aware that hostilities had advanced too far to remain unnoticed, requested that a council should be called, and as Lord Dunmore's troops approached, a white man named Elliott was sent to meet them, carrying a flag of truce. He asked for someone who could understand the Indian language.

Colonel John Gibson returned with him to Camp Charlotte, on Scippo Creek, and found Cornstalk waiting, in company with eight other chiefs and five hundred warriors. Though probably desiring peace, they had painted their faces half black and half red, to show their indifference.

In spite of all persuasion, Logan, embittered by his losses, refused to attend the council. According to Colonel Gibson's sworn statement, however, the chief met him, and they walked together into the woods, and sat on a log under the old elm. Captain Williamson, one of Dunmore's soldiers, identified the tree as the exact spot where the words were spoken which have become celebrated as "Logan's Speech."

"I appeal to any white man to say if he ever entered Logan's cabin, hungry, and he gave them not meat; if he ever came cold and naked, and he clothed him not? During the course of the last long and bloody war, Logan remained idle in his camp, an advocate for peace. Such was my love for the whites that my countrymen pointed as I passed, and said, 'Logan is the friend of the white man,' I had ever thought to have lived with you but for the injuries of one man. Colonel Cresap, the last spring, in cold blood and unprovoked, murdered all the relations of Logan, not even sparing my women and children. There runs not a drop of my blood in the veins of any living creature. This called on me for vengeance. I have sought it. I have killed many. I have fully glutted my vengeance. For my country I rejoice at the beams of peace; but don't harbor a thought that mine is the joy of fear. Logan never felt fear.

"He will not turn on his heel to save his life. Who is there to mourn for Logan? Not one."

On October 2, 1912, the old elm was presented by residents of Pickaway County to the State of Ohio, to be cared for and preserved as an historic relic.

The tree measures seven feet in circumference, and the spread of its branches is one hundred and fifty feet. Specialists have put it in fine condition, and it is protected by an iron railing, and bids fair to remain for many a year to come, as a monument to the memory of the Indian Chief, Logan, of whom it was said by his friend, Judge Brown, "He was the best specimen of humanity, white or red, I have ever encountered." 


\title{
Otd Elm Tree Corner
}

A tablet at the northwest corner of State and Pearl Streets, Albany, N. Y., bears this inscription:

"Old Elm Tree Corner. So named from a tree planted here by Philip Livingston about 1735. Removed 1877. Also the site upon which were published Webster's famous reading, spelling book and almanac, and the first Albany newspaper, the Albany Gazette, 1771."

A picture of the Old Elm hangs in the Albany Institute, Historical and Art Society Building.

The spot has also been celebrated by W. D. Morange, in the following lines:

\author{
"It don't appear that the Old Elm Tree \\ Was a slippery elm, you know; \\ But nevertheless it will doubtless be \\ Set down in the records so.
}

\begin{abstract}
When the snow congeals on the slanting grade,
Where the Elm Tree went to rot,

And scores of broken heads have made

Their mark on the sacred spot,

That place of broken skulls will be

By many a frantic mourner,

Set down in the town geography,

As the 'Slippery Elm Tree Corner'."
\end{abstract}

\section{Elm of the Colony of Transyluania}

In the middle of the 18th century, Kentucky was an unknown land to the white men. In 1760, John Finley and a few acquaintances made their way into the unexplored territory, and brought back with them glowing accounts of the beauties and fertility of the lands there. Daniel Boone accompanied him on a second expedition, and on returning, interested Colonel Richard Henderson, a young lawyer of North Carolina, in the wonderful region beyond the mountains. Much pleased with what he heard, Henderson conceived the idea of forming the Transylvania Company, to purchase a large tract of the land, and plant a colony of which he should be proprietor, selling titles to the settlers.

Daniel Boone had been selected to cut through the wilderness a highway over which emigration could pass to Transylvania, and on March 10,1775, set out with about thirty men toward Cumberland Gap, blazing the way on "mile-trees," and following the course of the "Warriors' Path," a famous Indian Trail between Virginia and Kentucky, which near the Gap, formed a link in the great war path from north to south.

On March 25, the little band camped at Silver Creek, where they were attacked by Indians, who killed one of their number; but fifteen miles further on, they reached the place previously selected by Boone and Henderson for their new home. Here they camped, on a plain, beautiful with white clover and Kentucky "blue grass." Two springs 
were nearby, and also four huge trees, three sycamores, and a great elm with which Colonel Henderson was much impressed: He said, "The diameter of its branches from the extreme ends is one hundred feet, and every fair day it describes a semicircle on the heavenly green around it, of upward of four hundred feet, and any time between the hours of ten and two, one hundred persons may commodiously seat themselves under its branches. This divine tree is to be our Church, State House and Council Chamber."

The convention of the "House of Delegates of the Colony of Transylvania" did meet under the elm on the 23rd of May, 1775. It was in session for three days, passing nine bills. "Henderson received full possession of the land from the Cherokees," as Boone's biographer, Lucile Gulliver, tells us, "according to a pretty, ancient custom. The lawyer representing the Indians, handed Henderson a piece of Kentucky turf, and together they held it while the lawyer declared the transaction completed."

While in all probability, the old elm might well have survived up to the present time, no historical association is on record as having preserved it, or marked its site. It would have been a picturesque and valued memorial of one of the most interesting sites of pioneer days.

\section{Daniel Boone's Judgment Tree}

On June 11, 1800, Colonel Boone was appointed commandant of the Femme Osage (Missouri) District.

* "It was about this time, or perhaps a little earlier, that he built the cabin near the spring in the Femme Osage Valley and removed his family there. The duties of his office were both civil and military, and his decision in all cases was final, excepting those involving land titles, which were referred to the crown or its immediate representative. Punishment for crime or misdemeanor was of the most summary character. The accused, if proven guilty, was tied up and whipped, the number of lashes being proportioned to the nature of his offense. A hickory sapling that stood in the yard near the spring served as a whipping post. That kind of punishment met the requirement of the age, and no thief or breaker of the law was ever known to resent a judgment rendered by Daniel Boone. He held his court under the spreading branches of a large elm tree, which still stands on the bank a few feet above the spring and is known as "Daniel Boone's Judgment Tree."

\section{Constitutional Elm of Indiana}

Under the spreading boughs of an elm at Corydon, first capital of Indiana, the Constitution of that State was adopted, nearly a century ago.

* Extract from article by William S. Bryan in the Missouri Historical Review. 
"When Benjamin Douglass was the State Entomologist in 1910," says E. M. Herschell, "he sent men from his office to Corydon, and the cavities in the historic tree were cleaned and then filled with concrete, much as a dentist fills a decayed tooth. The result of this treatment has been that the constitutional elm has taken on new vigor and probably will live through generations to tell its story of the pioneer upbuilding of a great state. Corydon's other historic treasure, Indiana's first capitol, still is in a good state of preservation.

An effort has been made to give the Statehouse Grounds in Indianapolis historic setting with trees, but the plan has not proved successful because of the apparent refusal of trees to grow in the Statehouse Yard. Shortly after the present state capitol was occupied it became a custom of the Governors to plant a tree representative of their administration. These trees, mostly maples, have been scattered over the grounds, but it is a sad fact that only a few have survived."

\section{The Morse Elm}

One of the first trees to be given a place in the Hall of Fame for Trees of the American Forestry Association, was the famous Morse Elm of Washington, D. C. Standing at the corner of Pennsylvania Avenue and Fourteenth Street, it has looked down upon every inaugural parade held in the national capital, and was one of the city's oldest landmarks, though owing to decay, it has been removed.

The tree was named for Samuel F. B. Morse, who often sat beneath it, talking to interested listeners of his wonderful invention, the telegraph. Groups of politicians were also to be seen discussing affairs of State in its shade.

When the Morse Elm was felled, its trunk was presented to the American Forestry Association.

\section{The Tappan Elm}

At Tappan, N. Y., near the quaint little house that served as Washington's headquarters, stands an elm that is associated with Revolutionary days. When, in 1783, arrangements were made for the evacuation of New York by the British, and the exchange of prisoners, a small tar barrel was hoisted up on a limb of the tree and set on fire, as a signal that the much desired end had been accomplished. It is said that the flames were visible on Manhattan Island, about twenty miles away. The De Wint house, a residence close by the elm, is believed to have been the meeting-place, where the papers necessary to the transaction were drawn up.

Only a few blocks north of the old tree stands the " '76 House," where Major André was imprisoned just before his execution, and the old Dutch Reformed Church where his trial took place. The monument erected to his memory is in the town of Tappan. 


\section{CHAPTER IX}

\section{The Roosevelt Sugar Maple-The Sugar Maple and the Indians- Early Mention of the Sugar Maple-The Sugar Maple and the Abolitionists.}

\section{The Roosevelt Sugar Maple}

A splendid sugar maple, in the Glenview Forest Reserve, five miles due west of Evanston, Illinois, was during the year 1820 christened in honor of Theodore Roosevelt.

It stands in a region of "virgin timber," forest land on which no living tree has ever been felled, and is the senior, by several hundred years, of its comrades, though all around it stand maples and oaks that are in the neighborhood of five hundred years old. According to prominent botanists, the age of the Roosevelt Tree may be safely estimated at one thousand years. Other tree experts say that it is at least not younger than seven hundred years. Its trunk measures nine feet, at breast height, and shows a clean bole up to fifty feet above the ground. Growing in dense timber, it is, of course, slim for its height. This tree, which will doubtless live to acquire fame, both on account of its title and its great age, is a worthy representative of the sugar maples of America, trees that are distinctively characteristic of this country, and that have played an important part in the everyday life of its early settlements.

\section{The Sugar Maple and the Indians}

It has been said that "If trees had human characteristics, the sugar maple would be the banker of the forest community because of its store of wealth. It is a conservative, dignified, well-dressed tree, conscientious, hardworking and dependable." The Indians appreciated its usefulness, and taught the earliest white pioneers on the shores of the Hudson, and in New England and the Middle States, to extract the sugar. They probably relied upon it for their entire supply of sweetening. It was also found possible to produce the flow by applying heat, and so procure sugar needed in case of sickness.

According to Baron de la Hontan, who traveled in America from 1684 to 1695, the "liquor is drawn by cutting the tree two inches deep in the wood, the cut being run sloping to the length of ten or twelve inches .... a knife is run into the tree slopingly, so that the water running along the cut or gash as through a gutter, and falling upon the knife that lies across the channel, runs out upon the knife which has vessels plac'd underneath to receive it. The gash do's no harm to the tree. Of this sap they make sugar and syrup which is so valuable that there can't be a better remedy for fortifying the 
stomach." The Baron also considered that the maple sap possessed "a much pleasanter taste than the best lemonade or cherry-water."

The sap was collected into troughs, by the squaws, and hot stones were plunged into it, and this process was continued until the sugar had boiled down to the desired consistency. The Baron saw two kinds of maples tapped; the black or hard, and the white or soft maple; "the former makes infinitely the best grained and flavored sugar, and fully equal in quality to the best Muscovado."

The Indians mixed maple sugar with melted bear's fat and made sauce for their roast venison; they used it to sweeten boiled corn, and the parched corn which they carried with them on journeys. The Iroquois Indians called the Algonkians "ratirontaks," "tree-eaters," on account of their fondness for sugar. There is an Algonkian legend that explains why maple sap runs so thin instead of being thick like syrup as it was originally.

One day, Nokomis, the grandmother of Manabush, was roaming through the forest, and by accident cut the bark of a tree. Seeing a rich syrup flow slowly from the wound, she tasted it, and delighted at finding it so delicious, gave some to Manabush. He also was much pleased with the new sweet-meat, but felt afraid that if the women of the tribe found the syrup could be obtained so easily, all ready-made as it were, they would become idle. So, in order to keep his aunts busy, he diluted the sap, making it thin, as we know it, by pouring water over the tops of the trees. This is why the women must boil down the sap to make syrup.

\section{Early Mention of the Sugar Maple}

One of the earliest references to maple sugar appears in an issue of the "Philosophical Transactions of the Royal Society," (England), published in 1684, "an account of a sort of sugar made of the juice of the maple in Canada." The writer tells us that "The savages of Canada, in the time that the sap rises in the maple, make an incision in the tree by which it runs out; and after they have evaporated eight pounds of the liquor there remains one pound as sweet and as much sugar as that which is got out of the canes. The savages here have practised this art longer than any now living among them can remember."

Lambert's "Travels Through Canada and the United States," published in 1813, mentions maple sugar (evidently one of the novelties of the New World), as being very hard and requiring to be "scraped with a knife when used for tea, otherwise the lump would be a considerable time in dissolving." Its flavor reminded the author of the candied horehound sold in England, and he added that the Canadians ate large lumps of the sugar believing it to act medicinally. "It very likely acts as a corrective to the vast quantity of fat pork which they consume, as it possesses a greater degree of acidity than the West India sugar. Before salt was in use, sugar was eaten with 
meat in order to correct its putrescencey; hence, probably, the custom of eating sweet apple sauce with pork and goose, and currant jelly with hare and venison."

Among the many plant specimens sent from the New World by the famous botanist, John Bartram, to Peter Collinson, of London, England, were seeds of the sugar maple, which occasioned much comment, the tree being practically unknown in England. Collinson had already written to his "Kind Friend John Bartram," (in 1735) :

"I am mightily pleased with thy account of the Sugar Tree. Pray send me a little sprig, with two or three leaves dried between a sheet of paper, and if thee canst, the blossom. We imagine, here it is a poplar or maple, but when we see the flowers or seed-vessel, we shall soon determine." Six months later, having received the specimens he wanted, he wrote to Bartram again:

"The leaves of the Sugar 'Tree are very informing, and are a great curiosity; but we wish thee had gathered little branches with the flowers on them and some little branches with the keys on them. The seeds of this tree (which, by the leaves and keys is a real Maple), I cracked a many of them, and not one has a kernel in them, which I am surprised at. We must desire thee, next year, to make another attempt and send us some specimens. Its bearing white blossoms is an elegance above any other of this tribe that I know of."

\section{The Sugar Maple and the Abolitionists}

One does not naturally associate the sugar maple with antislavery agitation, and yet the hopes of earnest abolitionists, one hundred and twenty-five or more years ago, were centered in this tree. As it would yield so easily and naturally such quantities of sugar, there seemed no further need for importing this necessary article from the West Indies, where it was produced from cane by the hard labor of slaves, nor for allowing such a condition to continue in the United States.

Monsieur J. P. Brissot, who published in 1788, an account of his travels in America, was evidently much impressed with the idea. $\mathrm{He}$ writes as follows: "Providence, my friend, seems to have placed in the bosom of the continent that slavery has sullied and tormented most cruelly, two great means which ought, inevitably, to work its destruction, that, is the society of which I have spoken to you, and the Sugar Maple. ... The settlers established in the middle of forests in America, limit themselves, hitherto, to a very slight manipulation to get this sugar . . . but since the quakers have perceived in this tree a means of destroying the slave trade, since to replace the cane sugar they have felt the necessity of perfectioning the Sugar Maple, more attention has been given to the manipulation, and success has crowned their efforts. You know, my friend, all the conditions that are necessary to be united for the cultivation of the sugar cane . . . the enemies and accidents that that plant fears (is subject to), the labor, its culti- 
vation, its preparation, and its fabric costs to the unfortunate Africans. Well! Compare these inconveniences with the advantages that the Sugar Maple presents, and you will again, once more, be convinced what great pains we often take to be uselessly criminal. . . . I wish there were formed from north to south a holy coalition to accumulate the produce of that Divine Tree, if above all, it were looked upon as an impiety to destroy so useful a tree, either for burning or clearing lands; America might not only furnish for its own use, but might also inundate the markets of Europe with a sugar, whose cheapness would, in time, annihilate that sugar which is sprinkled with the tears and blood of slaves, for the Maple Sugar does not cost but three-pence the pound."

The trees were abundant; the celebrated Dr. Rush, of Philadel-

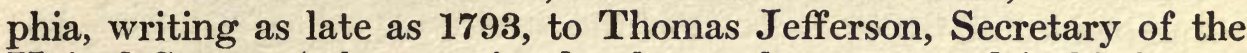
United States, (who permitted only maple sugar used in his household, and planted maples on his estate in Virginia, for the purpose of producing it), describes them as covering "five or six acres in a body, more often mixed with other trees." Generally, there averaged from thirty to fifty sugar maples on an acre, and residents of Pennsylvania are recorded, as making from two hundred to four hundred pounds of sugar per year.

Dr. Rush considered maple sugar an extremely healthy article of diet, and thought that its use might lessen malignant fevers. $\mathrm{He}$ quotes Sir John Pringle as remarking that the plague had never been known in any country where sugar was eaten in considerable quantities. However, there had hitherto been the insuperable difficulty"many persons refuse to be benefited, even indirectly, by the labour of slaves."

"I cannot help contemplating a Sugar Maple with a species of affection and even veneration, for I have persuaded myself to behold in it the happy means of rendering the commerce and slavery of our African brethren in the sugar islands, as unnecessary as it has always been inhuman and unjust."

Tench Coxe, of Philadelphia, Penn., author of "A View of the United States" (published in 1794), says that the total consumption of sugar and molasses in this country at that time amounted to twentysix million pounds, and that "every farmer having one hundred acres of maple sugar land in a state of ordinary American improvement ... can make one thousand pounds weight of sugar with only his necessary farming and kitchen utensils." 


\section{CHAPTER X}

Memorial Trees of Spiegel Grove-Lincoln Memorial Tree-Ginglko Tree at Grant's Tomb-Elms Planted by Royalty-Plantings by President and Mrs. Harding-Lincoln Memorial Grounds-Burroughs Memorial Forest-Tree to Theodore Roosevelt-Tree to Quentin Roosevelt-Unusual Alumnae Avenue-National Farm School-Memorial Trees of Philadelphia-Tree to "Humanity Martin"-New York State Memorial Highway.

\section{Historic Trees in the Making}

The idea of the tree as one of the most acceptable memorials has developed into the widespread custom of commemorative tree planting. Such memorials may be appropriately described as historic trees in the making. Those planted today, to quote from American Forestry, "will be famous fifty years from now and even more famous in a hundred years."

\section{Memorial Trees of Spiegel Grove}

Spiegel Grove, Fremont, O., the home of President Rutherford B. Hayes, contains a rare collection of memorial trees, and is, itself, historic ground. It is situated in the old Indian reservation which, long before the Revolution, was established at the lower rapids of the Sandusky River. The Harrison Military Trail of the War of 1812, the old French and Indian route from Lake Erie to the Ohio, runs through the grove for half a mile, and the deep ruts made by General Harrison's wagon wheels are said to be still visible.

The grove occupies part of the site of the free city of the Indian tribe of the Eries, who, three hundred years ago, erected two fortified towns opposite each other, at this point, on the Sandusky. During Revolutionary days, Daniel Boone and Simon Kenton were led prisoners through the grove, along the old trail, which long before their day, had been trodden by French explorers and missionaries, and which is said to have been the route traveled by more Indian captives than any other trail.

A number of the trees growing in this historic grove bear the names of Mr. Hayes' distinguished guests. Five immense oaks, under whose shade a table was spread on the occasion of the annual reunion of the 23rd regiment, September 14, 1877, were christened in honor of General Sheridan and four colonels of the regiment, who sat at the table. Other speakers of the day returned in later years, and their memory is similarly perpetuated, as shown by the naming of the McKinley oaks, the Chief Justice White oak, and the Garfield maple. On General Sherman's return from escorting Mr. Hayes and his party to the Pacific Coast, a particularly fine elm was given his name. 


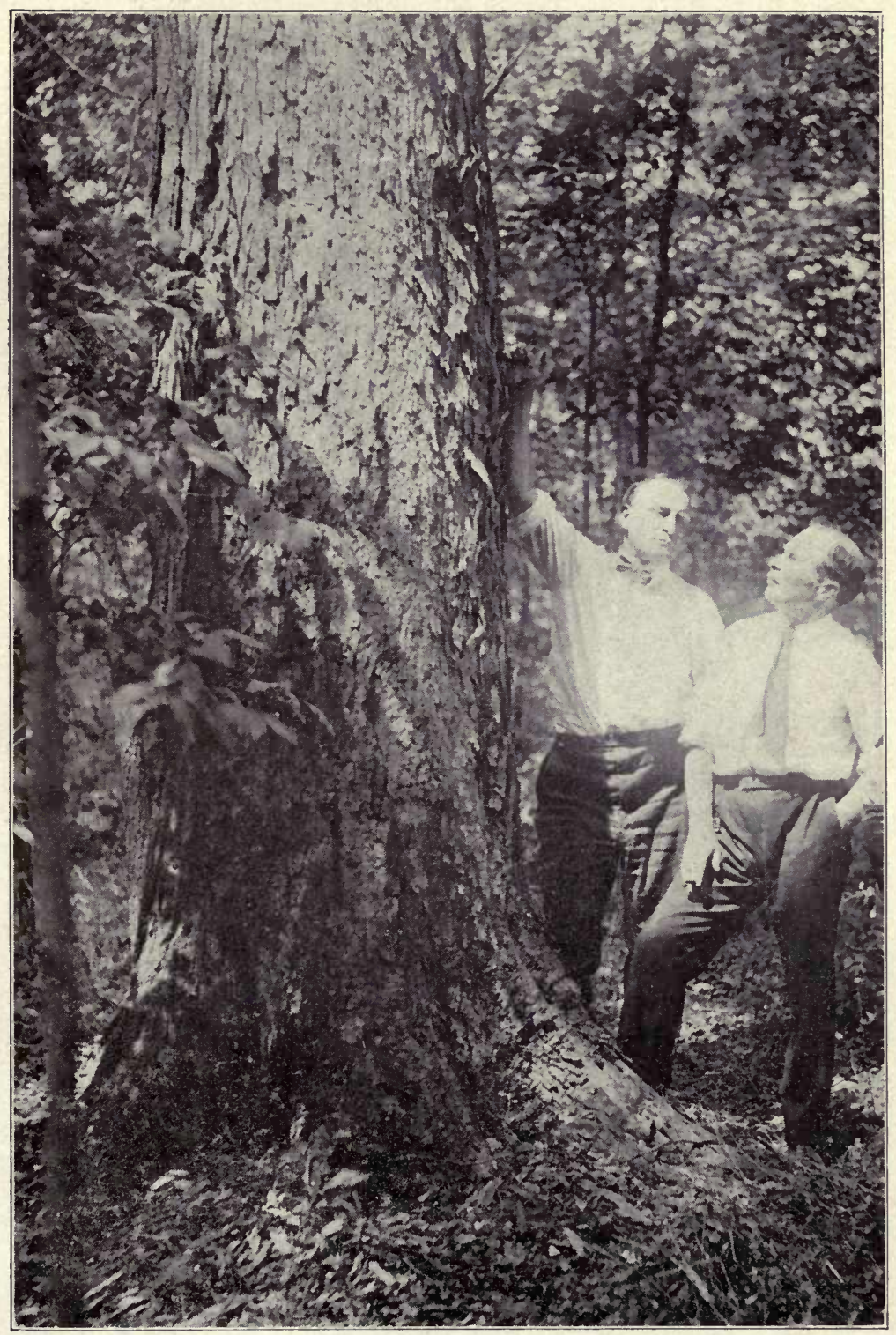

ROOSEVELT TREE

Immense Sugar Maple, Near Chicago, thought to be 7oo years old. Courtesy of the Chicago American. 

Other trees of interest in the grove are two oaks that have sprung from acorns of the famous Charter Oak of Connecticut, also tulip trees from James Madison's home in Virginia and the Cleveland hickory. It is related that Chief Justice of the United States Supreme Court William H. Taft was a guest at the grove when about to begin his campaign of 1908; he was requested to select his tree; laying his hand upon one of the finest oaks on the place, he remarked "This is about my size."

"Grandfather's Oak," standing close by the trail, where the ground bore, for many years, the deep print of "tramping moccasins," earned its fame through the incident of Mrs. Hayes' grandfather having camped beneath it during the War of 1812. Scars made by his camp-fire are still visible on its trunk.

The Lucy Hayes Chapel, named in her honor, was outlined in young walnut trees by Mr. Hayes, in a field bordering the Grove. It possessed "nave, transept and tower," and as he was accustomed to say, it was a chapel that "would be worth looking at two hundred years hence."

\section{Lincolin Memorial Tree}

On April 27, 1865, the day appointed by Governor Stone, of Iowa, as a day of mourning for President Lincoln, John Fine, of Decorah, Ia., dug up a hackberry shoot and transplanted it to the ground in front of his house. It has developed into one of the finest trees in the State, and is nearly one hundred and ten feet high and twelve feet in circumference. It is one of the few hackberries that has attained to any measure of note.

\section{Gingko Tree at Grant's Tomb}

In 1897, a gingko, or Chinese Maiden-hair tree, sent by Li Hung Chang, was planted at Grant's tomb, on Riverside Drive, New York City. It is marked by a bronze tablet, bearing the following inscription:

"This tree is planted by the side of the tomb of General U. S. Grant, ex-President of the United States of America, for the purpose of commemorating his greatness, by Li Hung Chang, Guardian of the Prince, Grand Secretary of State, Earl of the First Order Yong Hu, Envoy Extraordinary and Minister Plenipotentiary of China, Vice-President of the Board of Censors. Kwang Hsu, 23rd year, 4th moon, May, 1897."

\section{Elms Planted by Royalty}

The visit of the Prince of Wales to America in 1920, is commemorated by an English Elm which he planted in Central Park, New York City, one hundred feet from the spot where his grandfather, Edward VII of England, planted an American Elm, half a century earlier. The Prince was welcomed on this recent occasion by Charles 
Lathrop Peck, President of the American Forestry Association, and Dr. George F. Kunz, President of the American Scenic and Historic Preservation Society.

\section{Plantings by President and Mrs. Harding}

In memory of all the animals who lost their lives in the World War, an elm was planted by President and Mrs. Harding, on October 17,1821 , on the White House grounds just south of the east entrance to the house. This elm bears the distinction of being the first tree planted as a memorial to our animal friends. It is five years of age, and fifteen feet in height, and will be marked with a copper star, the marker used by the American Animal Red Star Relief Association. The ceremony took place in the presence of about one hundred spectators, among whom were Mrs. Wilson Groshans, of Illinois, who originated the idea of such a Memorial, and Mr. James P. Briggs, President of the Humane Education Society of Washington, D. C.

\section{Lincol.n Memorial Grounds}

The opening of Armistice Week was marked by the planting, on November 7, 1821, of two American Elms on the Lincoln Memorial Grounds at Washington, D. C. The trees, one of which was planted for the allied armies, the other for the allied navies, were dedicated by Charles Lathrop Peck, President of the American Forestry Association. They were placed at the head of the prospective avenue of memorial trees to be planted by various governments.

Mrs. Harding presented her tree planting trowel to members of the American Legion, who planned to use it in Chicago on Armistice Day at the opening of a Road of Remembrance, which will be several miles in length.

\section{Burroughs Memorial Forest}

The boys of the Raymond Riordon School Conservation Unit, under the Conservation Commission of the State of New York, have finished planting the first section of the Burroughs State Memorial Forest on Rose Mountain, New York. In memory of the famous naturalist, the hill is to be rechristened Burroughs Mountain, and the forest, largely composed of evergreens, is to be planted and cared for by the boys of the State.

\section{Tree to Theodore Roosevelt}

On Theodore Roosevelt's sixty-second birthday, a white oak was planted in memory of him, near his grave at Oyster Bay. The ceremony was arranged by the New York Bird and Tree Club, of which club the Colonel was a member, and the first shovelful of earth was thrown upon the roots of the tree by Mrs. Thomas Edison in behalf of her husband. This planting is thought to have launched the movement for commemorating Col. Roosevelt in this way all over the country. 


\section{Tree to Quentin Roosevelt}

At the Force School, Washington, D. C., a tree perpetuating the memory of Lieutenant Quentin Roosevelt, a former pupil there, is looked after by the children. A committee has been formed, consisting of one child from each class, whose duty it is to care for the tree. Each member has the privilege of choosing his successor, when passing to a higher class. This plan has found favor in a number of other schools, and should be further developed by making systematic provision for the protection of trees wherever situated.

\section{An Unusual Alumnae Avenue}

Mt. St. Joseph College of Chestnut Hill, Philadelphia, Penn., has instituted a new departure in alumnæ memorial planting. In November, 1921, an avenue of oaks was dedicated, leading from the bank of the romantic Wissahickon Creek, which forms the boundary of the convent grounds, to the door of the new college. About fourteen of the trees have been planted, the beginning of the stately avenue, which in time to come will develop into a walk of rare beauty. Memories of interest to friends and pupils of the college will cluster about it, as each oak will be marked with the name of one of the alumnæ.

\section{National Farm School}

The National Farm School, also near Philadelphia, Penn., possesses a grove of trees commemorating war heroes and friends of the school.

A novel feature has been added to the grove in the naming of Festive Trees in honor of birthdays, confirmations, betrothals and wedding anniversaries of those associated with the institution.

\section{Memorial Trees of Philadelphia}

Humanitarians of Philadelphia, Penn., have on several occasions celebrated Arbor Day by unique tree-plantings to commemorate events of national or local interest.

In 1916, a horse-chestnut was planted in Washington Square, in honor of the first general observance of Humane Week in Pennsylvania. 1917 saw the planting of three oriental planes, in the yard of the Wharton Public School, in honor of three citizens, women who were co-workers with Henry Bergh, and with him pioneers in the Anti-Cruelty Movement. The women thus commemorated were Mrs. Caroline Earle White, Miss Adele Biddle and Mrs. Annie L. Lowry.

On Arbor Day in the spring of 1918, a sycamore was planted on the new parkway, by the American Anti-Vivisection Society and the Animal Rescue League, of Philadelphia, in honor of the Third Liberty Loan. This occasion is memorable as the first treeplanting in the commonwealth attended by the United States troops 
in uniform. Governor Brumbaugh, of Pennsylvania, cast the first shovelful of earth, and Miss Leta Sullivan, a member of one of Philadelphia's most prominent families, selected on this occasion as being a member of both the societies in charge, raised the flag in signal for the military salute.

One year later, an elm, his favorite tree, was planted by the same Societies, in memory of Joyce Kilmer, the soldier-poet, whose exquisite verses entitled "Trees" should be familiar to every lover of nature. The ceremony took place in historic Logan Square, where the Sanitary Commission Fair was held during the Civil War.

\section{TREES \\ By Joyce Kilmer.}

"I think that I shall never see

A poem as lovely as a tree.

"A tree whose hungry mouth is prest

Against the earth's sweet flowing breast;

A tree that looks at God all day,

And lifts her leafy arms to pray;

A tree that may in Summer wear

A nest of robins in her hair;

Upon whose bosom snow has lain;

Who intimately lives with rain.

Poems are made by fools like me,

But only God can make a tree."

On the fall Arbor Day of 1920, (it being the custom in Pennsylvania to observe this day twice a year, in spring and autumn), Rittenhouse Square was the scene of a triple planting in honor of humane workers well known and well beloved throughout the city, Miss Katharine C. Biddle, First President of the Animal Rescue League; Mrs. Albert Hoffman, (formerly Miss Leta Sullivan), and Mrs. Emeline Reed Bedell. To each was assigned the tree known to have been her favorite. To Miss Biddle, a horse-chestnut; to Mrs. Hoffman, a black walnut; and to Mrs. Bedell, a hickory.

\section{Trees to "Humanity" Martin and Jack London}

The year 1922 marks the centennary of the first law passed in any country for the protection of animals. It was placed upon the statute books of England, (after a decade of opposition) thanks to the efforts of Richard Martin, an Irish member of the House of Commons.

The Centennial Anniversary of this epoch marking piece of legislation was fittingly commemorated on April 28th in Philadelphia, Pa., when humanitarians from all parts of the city gathered in the Muncipal Court Gardens to witness the planting of twin oaks presented by Judge Brown of that court. 
Noted for rugged strength and enduring usefulness, oak trees form the most appropriate memorials of the two reformers thus honored, Richard Martin and Jack London, whose splendid crusade against the exhibition of performing animals is well known.

Martin succeeded where his predecessors had failed, in a fashion peculiarly his own. In that memorable session of Parliament of 1822, he proved himself a man who could stand his ground in the midst of ridicule, and handle a difficult situation with ease.

To quote from Margaret M. Halvey, "Richard Martin knew and acted upon the knowledge that those who are cruel are always cowards; and so when his hearers .... greeted the "Anti-Cruelty Bill" with cat-calls and howls of derision, Martin held his peace throughout the uproar and then announced that he would personally chastise every man who had insulted him on the floor of the House and who wished now to give his name as willing to repeat the insult!

It is significant that not a single voice was raised in reply and the bill passed its second reading in absolute quiet! Following this occurrence, King George IV of England, who knew Martin personally, named him "Humanity" Martin, as he is still called in the annals of the day."

Certificates have been issued by the American Forestry Association to the Societies which inaugurated this beautiful custom in the City of Brotherly Love.

\section{New York State Memorial Highway}

The Memorial Highway extending from New York City to Buffalo, N. Y., will be planted with two thousand elm trees, during the spring of 1922, in honor of soldiers of the State who gave their lives in the World War. The College of Forestry of Syracuse University, New York, will furnish the trees for the first ten miles of the avenue.

"This is a move in the right direction," writes the Editor of the New York Evening Sun. "There is an urgent need in this country for the beautifying of the roads. Americans who visit France and other European nations are invariably struck by the splendid highways, to which the unending rows of splendid trees add such distinction and charm. On the other hand, European travelers in the United States can hardly avoid a feeling that our roads too often are designed only to facilitate transportation and add nothing to the beauty of the landscape." 


\section{CHAPTER XI}

White Willows in Pennsylvania-Pope's Willoro-Napoleon WilloresThe Inrood Tulip Tree-The Stockton Catalpas-Hamilton's Trees-The Treaty Tree of Grosse Ile-The Osage Orange.

\section{White Willows in Pennsylvania}

Benjamin Franklin has left us an interesting account of the introduction into Pennsylvania of the white willow, a handsome foreign tree which has now become naturalized.

Noticing a sprout on a willow basket that had been taken from a ship docking at a wharf on the Delaware, at Philadelphia, he gave the twig to Debby Norris, who planted it on her father's estate, Fairhill, near the city. It took kindly to the new environment, and became the progenitor of the white willows which are now so numerous.

\section{Pope's Willow}

The introduction of the weeping willow, originally an oriental tree, first into England and thence into America, forms an interesting bit of history.

A box of figs from Smyrna was sent to Lady Suffolk, of London, and her friend, Alexander Pope, who happened to be present, noticed an unfamiliar, green twig bound about the package. "This is something we are not accustomed to here," he said. "I will plant it in the garden of my home on the Thames and see what it.produces." So the twig found its way to the grounds of his villa at Twickenham, England, and a graceful weeping willow was the result.

Long afterward, a British officer, starting for America during the Revolutionary War, took a shoot from the tree, intending to transplant it to the estate he expected to receive there when the Royal Arms should have won success. When the war terminated differently from his expectation, he presented the twig to John Park Custis, Washington's step-son, who planted it on his estate, in Virginia.

In 1790, General Gates transferred a shoot from it to his farm on Manhattan Island, N. Y., where it flourished and became known as "Gates' weeping willow tree." As New York City spread and business crept up to the site of his farm at Third Avenue and 22nd Street, the tree, well advanced in years, was felled in $\mathbf{1 8 6 0 .}$

A similar fate overtook the parent tree, Pope's willow, at Twickenham, which was cut down by a subsequent owner of the property because he was annoyed by the number of visitors, who came to admire it and carry away bits of wood as souvenirs. 


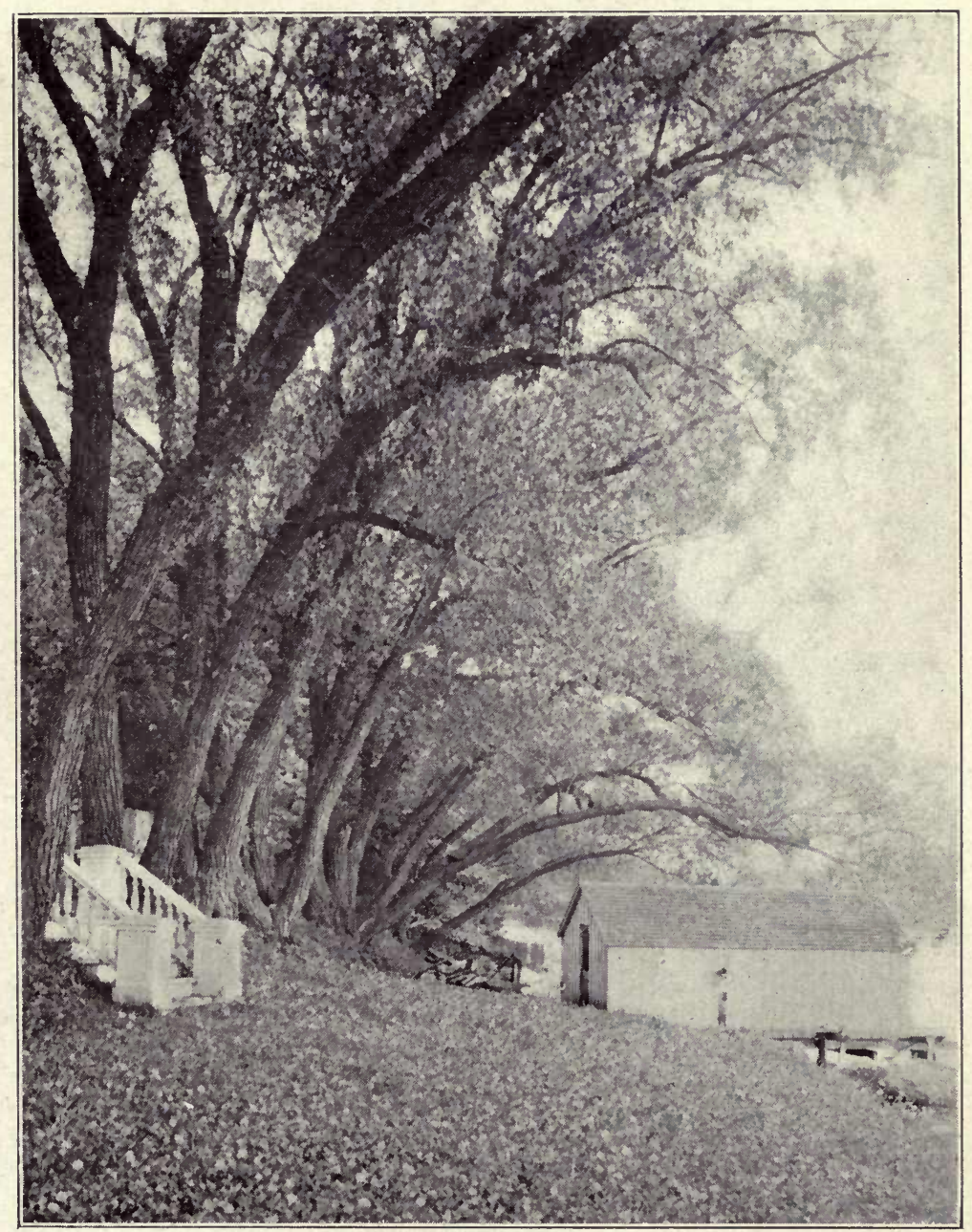

WILLOWS ON LAKE MENDOTA, MADISON, WIS.

Grown from cuttings of willows at Napoleon's grave, St. Helena. Photo by L. W. Brown, Madison, Wis. 



\section{Napoleon Willows}

Other weeping willows have been grown in America from cuttings taken from a tree of that species which shaded Napoleon's grave on St. Helena. It was his custom to sit beneath a weeping willow there, perhaps brooding over his misfortunes, and oddly enough, the tree was destroyed by a storm, about the time of his death. Madame Bertrand, a close friend, planted several cuttings from the willow beside the railing surrounding his tomb, and slips from these trees have been brought.from time to time, to this country.

One of the descendants of the Napoleon willows which, for nearly half a century has beautified the Phillips estate in Newark, N. J., has been described by Mr. Carl Bannwart as "the archbishop of this green diocese of Phillips Park." The tree was brought to John Morris Phillips, owner of the estate, which he has presented to Newark as a city park, by a friend, who cut it from one of the original trees on St. Helena, knowing Mr. Phillips' fondness both for trees and for any relics associated with Napoleon. Unfortunately, the historic willow shows signs of decay, and has so far failed to respond to the efforts of tree surgeons.

Another Napoleon willow was brought from St. Helena, about seventy years ago, by the late John T. Brown, of Providence, R. I. When the tree was well grown, he gave a slip from it to a relative in Wisconsin, and later transplanted back to Providence a slip from the Wisconsin tree, which had become strong and sturdy. This greatgrandchild of the willow on St. Helena is now flourishing in Providence, and a cutting from it has been planted in Swan Point cemetery there.

On the shore of Lake Mendota, Madison, Wis., near the foot of North Livingston Street, is a row of handsome willows grown from cuttings that were brought by a sea captain from the grave of Napoleon on St. Helena.

\section{The Inwood Tulip Tree}

The fine old tulip tree at the eastern base of Inwood Hill, on the northern end of Manhattan Island, is considered Manhattan's oldest tree. As its age is estimated to be two hundred and twenty-five years, it was in its youth when Henry Hudson made his memorable voyage of discovery on the river, and during the eventful years that followed, the tree was a silent witness of many interesting developments.

Standing on the shore of Spuyten Duyvil Creek, it recalls, among other incidents, the lively career of Anthony Van Corlaer, the trumpeter, a noted character of the days of Dutch occupation, when his friend, Peter Stuyvesant, was Governor of New Netherlands before the English had changed the name of the province to New York. It was owing to Van Corlaer's escapades, according to the old legends of the region, that both Anthony's Nose, a bluff in the Highlands of the Hudson, and also Spuyten Duyvil Creek received their names. As 
he was attempting to cross the creek one stormy night, when on a political mission, friends tried to dissuade him from the dangerous undertaking, but nothing daunted, Anthony insisted as he waded into the turbulent waters, that cross he would, "en spuyt den duyvil" Promptly, the "duyvil" appeared, in the form of a huge monster, and disappeared with the luckless trumpeter beneath the waves. But it is said that blasts from the latter's trumpet can still be heard arising from the creek on stormy nights.

The city's Park Department has preserved the ancient tree, filling its cavities with cement, and protecting it with an iron railing. On the surface of one of the cement fillings is the following inscription in gold letters: "Tulip Tree, Liriodendron tulipifera. Circumference 19 feet. Age 225 years. Henry Hudson entered this inlet in 1609 and may have met the Indians here who used the place for a camp, as shown by the quantity of old broken oyster shells around this tree and near by."

\section{The Stockton Catalpas}

The fine avenue of catalpas shading the lawn of the Inn at Princeton, N. J., are a memorial to Richard Stockton, the well known "signer" of the Declaration of Independence, who is thought to have brought the trees from England in 1762. The grounds were a part of Stockton's estate, Morven. His old house, still standing, was a favorite meeting-place for the patriots of those days.

"For more than one hundred years," says John Frelinghuysen Hageman, in his "History of Princeton and Its Institutions," "These ancient witnesses have borne testimony to the taste and unselfish instincts of this noble man. This long row of catalpas in front of Morven can only be viewed as a sacred memorial to the signer of the Declaration. The fourth day of July is the great day in Mr. Stockton's calendar, as it is in that of our country, and these catalpas, with the undeviating certainty of the seasons, put on their pure white blooming costume every Fourth of July. And for this reason they have been called, very fitly, in this country the "Independence Tree."

\section{Hamilton's Trees}

Following the Constitutional Convention, which met in Philadelphia, Penn., in 1787, the first Secretary of the Treasury planted thirteen sweet gum trees on the grounds of his home, Hamilton Grange, in New York City, to commemorate the entrance of the thirteen original States into the new Federal Union.

For many years the trees survived him, and a few remained as late as 1911, but then were removed to make way for building operations. The same fate befell the three tall sycamores at 140th Street and Hamilton Place, said to be the trees under which the seconds met, just before the duel between Hamilton and Burr, which resulted so disastrously for the former. 
One cannot help echoing, regretfully the words of Mrs. J. J. Wilder, President of the Georgia Society of the Colonial Dames of America, "If our patriotic societies had been founded earlier, how much might have been saved. ..."

The late Professor Lucien M. Underwood, a director of the New York Botanical Garden, in a lecture delivered in 1902, told of the amusing misstatements made about the sweet gum trees by a number of newspapers and magazines, which described them variously, as oaks, maples and elms; one of Hamilton's grandsons insisting that they were lime trees, brought from Washington's home at Mt. Vernon.

As Professor Underwood states, however, the trees were "not oaks and not maples and not elms and not limes (or lindens) but plain straightforward examples of sweet gum (Liquid Amber) a tree not uncommon in the native forests about New York, and yet one whose corky-winged twigs are sometimes sold on the city streets as 'rare alligator-wood from the tropies."

\section{The Treaty Tree of Grosse Ile}

The magnificient old basswood or linden tree of Grosse Ile, Mich., the largest of the group of islands at the mouth of the Detroit River, was witness of an important transaction, two days after the signing of the Declaration of Independence.

The island had long been a place of historic note. It was the home of the Potawatamie nation, and while Chief Pontiac besieged Detroit, afforded a camping ground for the Hurons. Other Indians, also made it their headquarters when attacking the boats that came from Niagara to relieve the garrison in a state of siege nearby. Grosse Ile was situated on the trade route connecting Albany, Detriot and Macinac and frequented by white fur-traders and Indians. Cadillac considered it as the site of the city of Detroit, Mich., but abandoned the idea, fearing there was not sufficient timber. In1707, he deeded the island to his daughter.

The old linden had flung its shade over many a negotiation between the whites and the red men. Under its branches, on July 6, 1776, a treaty was signed, conveying the island to two merchants of Detroit, Alexander and William Macomb, who purchased it for a little money, blankets and tobacco. It was of great importance that the island should pass into American ownership, otherwise, "division of the waters of the great Detroit River might have been changed."

Several Indian tribes were represented on this solemn occasion, the Fox and Sacs tribes, the Kikapoos and Potawatamies all being mentioned. The chiefs signed the agreement by drawing their totems on the deed, a fish, bear, wild cat, doe, deer, fawn with one leg, etc. One of these totems is the first sketch of the American eagle known to exist anywhere. The chief's eldest sons, not yet warriors, signed by making their thumb-prints. Tecumseh, "the torch of the North West" was one of the chiefs who signed the document. 
On June 1, 1811, the United States Government ratified the treaty, President James Madison granting by patent the land to John W., William and David Macomb, heirs of William. On July 3, 1901, the old Treaty Tree fell, the victim of a severe storm. Like many another veteran, it is represented by a younger generation, a sapling having sprung from its roots.

In 1906, on the 130th anniversary of the purchase of the island, the Woman's Improvement Association of Grosse Ile, marked the site of the old tree with a bronze tablet placed upon a large boulder. During the ceremony, the tablet was unveiled by a direct descendant of the Macombs. The inscription reads as follows:

"This stone marks the location of the Treaty Tree and commemorates the conveyance by treaty of Grosse Ile (known to the Indians as Kitche-Minishon) and the adjacent islands to William and Alexander Macomb by the Potawatamie Indians. The treaty was signed by eighteen of the chiefs of the Potawatamie nation of Indians.

The events of the past shape the pathway of the future.

Erected by the Woman's Improvement Association of Grosse Ile, 1906. The dee is recorded in the register of Detroit, No. 2, Vol 6. p. 19."

\section{The Osage Orange of New Harmony}

In 1824, the Rappite community of New Harmony, Ind., was purchased by Robert Owen, a believer in the community system, and William Machen of Philadelphia, Pa., a noted geologist. Under their leadership, New Harmony "soon became the mecca of scientists, a settlement which indeed, failed to realize the hopes of its founder, yet which served to awaken that scientific spirit which has never died out in Indiana."

A tree which still flourishes, commemorating the palmy days of the community, is the Osage Orange, planted there in 1826, by Thomas Say, the naturalist. Nuthall, the botanist, named it "Maclura aurantiaca" in honor of Maclure.

Today, its trunk measures eleven and one-half feet around, branching six feet from the ground. 


\section{CHAPTER XII}

Bartram's Cypress-The Cypress of Nere Bern-The Cypress of Painters' Arboretum-The Elgin Yeros-The Haddon Yers.

\section{Bartram’ Cypress}

Until the early summer of 1920 , when a severe storm laid it low, one of the chief objects of interest in Bartram's Garden, Philadelphia, Penn., was his famous cypress, which he brought as a sapling from Delaware, more than a century and a half ago. Looking about to find a switch for his horse, it is said, he pulled up the tiny cypress, but instead of using it for that purpose, carried it home and planted it, prophesying that it would "grow to a great height." The prediction was fulfilled, as it attained to more than one hundred and fifty feet, with a girth of seven feet. Long a noted tree, it had been protected by an iron railing from the depredations of relic hunters.

\section{The Cypress of New Bern}

A short distance from the edge of the Neuse River, at New Bern, N. C., is a fine old cypress formerly owned by Governor Spaight of that State.

The tree's age is uncertain, but it was probably well grown before the first Swiss settlers arrived from Berne. There is a tradition that the first boat ever built in those waters was fashioned beneath its shade, and then launched into the river. It was in Revolutionary days, as one of its admirers observes, that "the tree became a personality."

In 1781, following the defeat of General Gates by Cornwallis, General Nathaniel Greene, who saved the American army at the Brandywine, came to New Bern to consult with Governor Spaight. The Army of the South was a wreck, and without funds nothing could be done to rescue it. General Greene and the Governor met under the cypress to discuss the matter, and there the latter pledged the resources of the State, as well as his own private means to meet the emergency.

Success quickly followed the reorganization of the army, and the British were defeated at Eutaw Springs.

After becoming President, Washington made a visit to New Bern, and on being told the story of the cypress, walked over to the spot and rested under its shade, his intimate friendship with General Green probably serving to emphasize his interest in that memorable conference. 


\section{The Cypress of Painters' Arboretum}

A cypress tree, worthy of note, stands in the old botanic garden near Media, Penn., known as Painters' Arboretum. In 1825, the two botanists, Jacob and Minshall Painter, began planting their collection of rare shrubs and trees on their home farm, a tract of land taken up by patents from William Penn, and settled by Jacob Minshall in 1701. The old place bears the distinction of never having been sold, but always descending from one member of the family to another.

One of the most interesting features of the garden today, is the old cypress, which illustrates in a striking manner the influence of environment upon growth. This tree, which bears flat narrow leaves like an evergreen, sheds them in the autumn and further surprises us by altering its appearance according to the moisture of the soil in which it grows. When standing near water or in swampy ground, its branches are low and spreading, and all about its base, as in the case of the Painters' cypress, curious knobby growths, called knees, push up through the grass.

They are evidently extensions of the roots and are for the purpose of conveying air to them, for when the water is drained off, the knees disappear as though their mission had been accomplished. They are not to be found around a cypress standing in dry ground, and in such surroundings the tree changes its appearance still more, rising tall and slim, and bearing its branches chiefly on the upper part of the trunk.

\section{The Elain Yews}

The ancient spreading yew trees of the South Court of Columbia University, New York City, were for long years familiar features of the college grounds, forming as they did a cherished link between the University of the present day and that of one hundred years ago. They were survivors of the Elgin Botanic Garden founded by Dr. David Hosack, Professor of Botany and Materia Medica in the college from 1795 to 1811.

Having long wished for a botanic garden, the doctor, in 1797 , began urging the trustees to have one planted. Failing to accomplish this, on account of lack of funds, he petitioned the Legislature, but again no success. At length, in 1801, he purchased with his own money, twenty acres on the Middle Road between Bloomingdale and King's Bridge, about three miles and a half distant from the city, and named the little park the Elgin Botanic Garden.

Here he built a conservatory and two hot houses, surrounding them with a "belt of forest trees and shrubs, both native and exotic." A large oil painting of the garden at that time, hangs in the Administration Building, Bronx Park.

In 1811, the State purchased the garden from him, but three years later ordered it broken up, probably because the expense of maintaining it was too heavy, and directed "a list of the different kinds of 
plants, flowers and shrubs in said garden be sent to each of the other colleges in the State." Within one year, the trustees of Columbia College were required to deliver at least one healthy plant of each kind to each college that applied for it. None appear to have applied, however, and in 1819, or soon afterward, the trees and other plants of the garden were presented to the New York Hospital, which had purchased large property at Bloomingdale, now Morningside Heights. The acceptance of the gift appears in the Hospital Report for 1821 .

Long before Columbia University bought the site, the fine old English yews were conspicuous on the front lawn of the hospital grounds. When the estate passed into its new ownership, they seemed even more appropriately placed in academic surroundings. They have been described as "monuments to the past and a memorial of a man whose efforts have borne greater fruition in the Botanic Garden which the city now possesses than even he could have hoped."

\section{The Haddon Yews}

Longfellow's beautiful poem "Elizabeth," has immortalized one of the earliest and most unique romances of the New World. A modern house was long ago erected upon the site of the old Haddon Homestead, at Haddonfield, N. J., the scene of the story, but today, if fortunate enough to have the permission of its owner, one may visit the old place with its historic setting, associated with the days of some of the first Quaker settlers.

Elizabeth Haddon was the daughter of a wealthy Englishman, a member of the Society of Friends, and the holder of property in New Jersey, on the site of the future town of Haddonfield. Firmly convinced that she was called by the "Inner Light," to leave her English home and friends and cast in her lot in the New World, she obtained her father's consent to cross the seas to America and settle on his land there. One stands aghast at the courage and determination of the quiet Quaker maiden of nineteen, but the Divine call was to be obeyed, and in 1701 she carried out her purpose, bringing with her, among other cherished possessions, a bucket of slips from yew trees in the home garden.

These she planted in front of her dwelling in the wilds of "the Jerseys," and taking kindly to their new quarters, they grew, and flourished for many a year, their fame increasing with time and with growth of popular interest in historic landmarks. Two of the yews still ornament the old garden. Many a tale they might tell, to an ear that could hear, of the coming and going of men and women of note in the colonies, for the Haddon Homestead became a centre of hospitality. And there were many guests of humbler origin, for at the back of the dwelling-house still stands the little building where the mistress of the home made and distributed medicines and cordials to the Indians. 
Busy as she was, in her new life, there was one face which Elizabeth had never forgotten, that of the young Quaker, John Estaugh, whom she had heard speak "as if he were John, the Apostle," at "the great May-Meeting in London." His stirring address had sunk into the heart of the young girl, making a deep impression, and their meeting was unto her a constant memory during the changing years that followed.

And now, on some errand of business or mercy, Estaugh, too, had come to the colony. The poet tells us how, journeying through the winter night, he met another lone traveler, who, as they went on together, told him of Elizabeth and her comfortable home and her many good deeds. Perhaps the urge of old memories was even stronger than the need of a night's shelter. At all events, he lost no time in seeking the latter, and was made welcome.

"Youtheul he was and tall, and his cheeks aglow with the night-air;
And as he entered, Elizabeth rose, and going to meet him,
As if an unseen power had announced and preceded his presence,
And he had come as one whose coming had long been expected,
Quietly gave him her hand, and said, 'Thou art welcome, John Estaugh.'
And the stranger replied, With staid and quiet behavior,
'Dost thou remember me still, Elizabeth? After so many
Years have passed, it seemeth a wonderful thing that I find thee.
Surely the hand of the Lord conducted me here to thy threshold"."
And Elizabeth answered demurely:
"Surely the hand of the Lord is in it; his Spirit hath led thee
Out of the darkness and storm to the light and peace of my fireside!"

When the guest took his departure, next morning, in the glory of the winter sunshine, it was with the promise to return at the meeting to be held in May. Long and cold were the months that intervened; full of cheerful labor, full, too, of quiet meditation, and when spring came with its "rush of blossoms and music," the inner voice once more insistently called, and again Elizabeth obeyed.

Quarterly meeting was about to open, and John Estaugh, with a party of Friends on their way to attend it, stopped at the Haddon Homestead, for refreshment. As they were leaving, the young mistress of the house called him aside, and telling him she had somewhat to say in private, asked him to wait. Together, they rode through the leafy woods, and then, faithful to her call, she unburdened her mind:

"Then Elizabeth said, though still with a certain reluctance,

As if impelled to reveal a secret she faln would have guarded:

I will no longer conceal what is laid upon me to tell thee;

I have recelved from the Lord a charge to love thee, John Estaugh."

The poet has told us how John Estaugh, "surprised by the words she had spoken," urged that his business must be finished before he could consider them; how he returned to England for a time, and then "came back o'er the sea for the gift that was offered."

In the old garden, where tradition tells us the lovers spent many happy hours, the yews kept silent watch through the years that followed. Long since, those first owners have passed away, but the old trees survive. "They are waiting for you," says Wilhelm Miller, 
"just where you would expect to find them, at the old trysting place. They brood over the centre of the garden like Philemon and Baucis, and are stationed on either side of tht main walk. Unfortunately, both trees were badly hurt by the continental ice storm a few years ago, and it is doubtful whether they will survive another century." 


\section{CHAPTER XIII}

The Pines of Roanoke Island-The Pines of Canastota-Coaquannock

-The Delancey Pine-The Old Pine of Dartmouth College.

\section{The Pines of Roanoke Island}

Roanoke Island, N. C., is distinguished as the spot where Sir Walter Raleigh founded the first English colony in America. This historic ground is still marked by old Fort Raleigh, where on August 18,1587 , occurred the birth of Virginia Dare, the first white child born on the American continent.

Close by the fort stood two ancient pines, both trees of note and witnesses of the early days of the Lost Colony, as the little band of settlers has been christened. One of the oldest and most picturesque of Indian legends is that concerning the fate of Virginia Dare, after the colony had removed to the mainland where she was believed to have grown to young girlhood.

The friendly Croatoan Indians among whom the colonists had settled when forced to flee from the savages of Roanoke, reverenced the white maiden and called her Wi-no-na Ska, First-born White Daughter. O-kis-ko, one of the finest of the young braves, was madly in love with her. But he had a rival in Chico, the Sorcerer, who, though old enough to be the girl's father, was determined to wed her or to allow no one else to do so. Virginia did not fancy Chico, of that the crafty old man was aware, but the kind-hearted maiden would not offend him and was always gracious to her ancient suitor, though O-kis-ko was her choice.

As the earliest settlers had found, the rivers of the region abounded in "great store of mussels in which there are pearls," and Chico, versed in the secrets of Indian magic, set about utilizing them for his purpose.

\footnotetext{
"Such pearls are the souls of Naiads,

Who have disobeyed the Sea-King,

And in mussel-shells are prisoned

For this taint of human frailty.

When by man released from durance

These souls, grateful for their freedom,

Are his slaves, and ever render

Good or evil at his bidding.

Chico steeped each one he gathered

In a bath of mystic brewing;

Told each purple, pieded pearl-drop

What the evil was he plotted.

Never once his purpose wavered,

Never once his fury lessened;

Nursing vengeance as a guerdon

While the mussel-pearls he polished."
}

Then, having built a canoe for the occasion, and invited Virginia to paddle across to Roanoke with him, in search of grapes, he pre- 
sented her with the necklace he had made. The pearls, lying close about her white throat, could do her no harm while on the water, for there the Sea-King held sway, but when the canoe grated on the pebbles of the island, and she stepped ashore, the maiden vanishd, and in her place a white doe sprang gracefully forward and disappeared in the thicket.

As Chico floated swiftly away, his song was borne over the water:

\author{
"Go, white doe, hide in the forest, \\ Feed upon the sweet wild grasses; \\ No winged arrow e'er shall harm you, \\ No red hunter e'er shall win you; \\ Roam forever, fleet and fearless, \\ Living free, and yet in fetters."
}

Far and wide Virginia's friends searched for her, but without success. Then O-kis-ko overheard the old women sagely whispering to one another of Chico's wiles, saying that he had bewitched the girl, and changed her into a white doe. Believing them, O-kis-ko tried, in vain, to capture the animal. At length, despairing, he sought Wenau-don, the magician of Po-mou-ik, who had long cherished a grudge against Chico: We-nau-don had bathed in the Naiad's magic spring, whose powerful waters held the secret of perpeutal youth and brought success in love. He instructed O-kis-ko to make an arrow of witch hazel and fasten it to a triangle of three purple mussel-pearls, and a heron's wing, and taught him to repeat the charm,

\footnotetext{
"Mussel-pearl arrow, to her heart go;

Loosen the fetters which bind the white doe;

Bring the lost maiden back to O-kis-ko."
}

Wingina, a neighboring chief, becoming annoyed at the tales he heard of the white doe that none could take prisoner, made a feast and invited the tribes to join in a hunt for her. The Croatoans did not reply to the invitation, for they believed the doe to be Virginia's spirit, and fearful of harming her, would take no part in the chase. O-kis-ko, thinking to set the maiden free, offered to try his arrow and so did a boastful hunter named Wau-che-se.

On Roanoke Island, Wau-che-se stationed himself beneath a pine tree, while O-kis-ko was concealed in the shrubbery nearby. In a few moments, the white doe appeared, stepping cautiously, at the head of the herd. O-kis-ko bent his bow and softly repeating the charm three times, sent the dart of witch hazel straight to her breast. The deer vanished and before him stood the lost maiden. But scarcely had he beheld her before she fell at his feet, slain by Wau-che-se's silver arrow, begging O-kis-ko, with her last breath, to remember her forever.

As Virginia's blood mingled with the water of the magic spring by which she had fallen, it became dry, and O-kis-ko, bending eagerly forward, saw a little green shoot springing up from the bed of the spring, toward the sunlight. Sorrowfully he buried the silver arrow under the twigs and leaves, and inconsolable at his loss, visited the spot 
again and again. The tiny shoot that he had seen grew swiftly till it formed a leafy bower where the spring had been.

O-kis-ko, sitting often beneath its shade, noticed that clusters of rich purple grapes hung from the branches and yielded red juice instead of the white wine to which he had been accustomed. Tradition says that this was the origin of the purple Scuppernong grape, a vine that was abundant in the vicinity, but had formerly borne only white fruit. Believing the red juice to be the lost maiden's blood, O-kis-ko came frequently to drink it, praying that it would nourish him and lead him to her hereafter.

The legend of the white doe is found, at least in part, "wherever in our land forests abound and deer abide." A white doe is considered an evil omen, and it is believed that only a silver arrow is fatal to her.

Though the members of Raleigh's settlement on Roanoke were long known as the Lost Colony, on account of their complete disappearance from the island, the title is a misnomer. There is little doubt that they found a home among the friendly Indians of the mainland, and that their descendants are living in North Carolina today.

Sir Francis Nelson, who visited the region about 1608, recorded that he was told of people living inland "who wore clothes and lived in houses built with stone walls, and one story above another, so taught them by the Englishmen who escaped the slaughter of Roanoke." Lawson, the first historian of the Carolinas, says he learned from the Hatterask Indians that several of their ancestors were white people and could "talk in a book." A tribe of Indians living in Harnet and Robeson Counties, N. C., believe themselves to be descended from Raleigh's colonists and the Cherokee Indians, who lived together along the Neuse River. The Croatoans show evidences of white blood, being good builders, and having to their credit some of the best roads in the State, over one of which, the Lowrie Road, a messenger carried the news of the Treaty of Ghent to General Jackson, in 1815. This tribe is also remarkable as speaking more correct English than many of their white neighbors.

In 1906, the younger of the two pines at Fort Raleigh was cut down, as it had for some time showed signs of decay. Close to the centre of its trunk an arrow-head was found inbedded, probably shot there by an Indian when the tree was a sapling, nearly four centuries ago. Its companion, known as the Eagle Pine, had a wide-spreading top used by eagles for a nesting-place for uncounted years, until in 1876 a storm laid the great tree low.

\section{The Pines of Canastota}

Canastota, N. Y., was originally an Indian village and derived its name from an Indian word Kaniste, "cluster of pines"; the suffix, sota meaning "still silent, motionless." The three tall pines, from which it took its name, grew on the bank of Canastota Creek, and 
one which had partly fallen, lodged in the branches of the other two, forming a bower that became a favorite resting-place for the red men. The trees were appreciated and preserved by Captain Reuben Perkins, first white settler of the region. When he obtained the patent for the site in March, 1810, he built his home beside the cluster of pines.

\section{CoaquanNock}

When William Penn founded his City of Philadelphia, on the bank of the Delaware, he chanced upon a place already noted for its trees.

Before the coming of the white men, perhaps centuries earlier, the Indians had called the spot Coaquannock, "The place of tall pines," distinguishing it by the beauty of these rugged evergreens in a region thickly grown with forest trees of various sorts. "The woods of oak, hickory and firs covering both shores made a fine appearance," wrote Peter Kalm, the Swedish botanist, more than half a century later, describing his voyage up the Delaware, even long after its rich woodland had been thinned by the settler's axe.

John Watson, the city's chronicler, tells us that in 1682, the year of Penn's treaty with the Indians, Philadelphia had "a high and dry bank, next to the water, with a shore ornamented with a fine view of pine trees growing upon it." He adds that, as the ship "Shields from Hull" sailed up the river, a few years earlier, its masts became entangled with the branches of overhanging trees, and one of the passengers exclaimed, "What a fine place for a town!"

\section{The Delancey Pine}

The Delancey Pine, one hundred and fifty feet in height, which stood within the boundaries of New York City's Zoological Park, numbered its years at three hundred and sixty, when it was felled in 1912. More than a century previous it had shaded the home of the Royalist, Colonel James Delancey, of the Westchester Light Horse, High Sheriff from 1770 to 1777.

\section{The Old Pine of Dartmouth Coliege}

The "Old Pine" of Dartmouth College at Hanover, N. H., dated back at least as far as 1783. It has been endeared to the alumni as the centre of class-day exercises and other celebrations (one of which was the tarring and feathering of a man who was charged with crime,) during the greater part of a century. General Scott's nomination was marked by a cannon salute from under its branches, but as Professor Hubbard's house was struck by a stone, mischievously smuggled into the cannon, festivities ended abruptly.

There was a tradition, which proved to be unfounded, however, that in the early days, three Indian students stood around the old tree, singing in farewell to one another, "When shall we three meet again?" 
The legend was a singularly appropriate one, as Dartmouth College was founded for the education of the Indians, funds for it having been collected by Samson Occum, the Mohican who accompanied Whitefield to England, and there stated the claims of his people. $\mathrm{He}$ received contribution to the amount of $\$ 6,000$ (some of it from the King) which he devoted to the needs of the College.

In 1892, the news spread among the alumni, "The Old Pine is dying;" efforts were made to preserve it, but to no avail, and in 1895 it was cut down, the last class-day having been celebrated beneath its branches. The tree was seventy-one feet high, and a shot was found imbedded in the seventy-ninth ring from the outside. The stump, four feet in height, is all that remains to tell the tale of former grandeur. It has been treated with a preservative, and is a valued relic. 



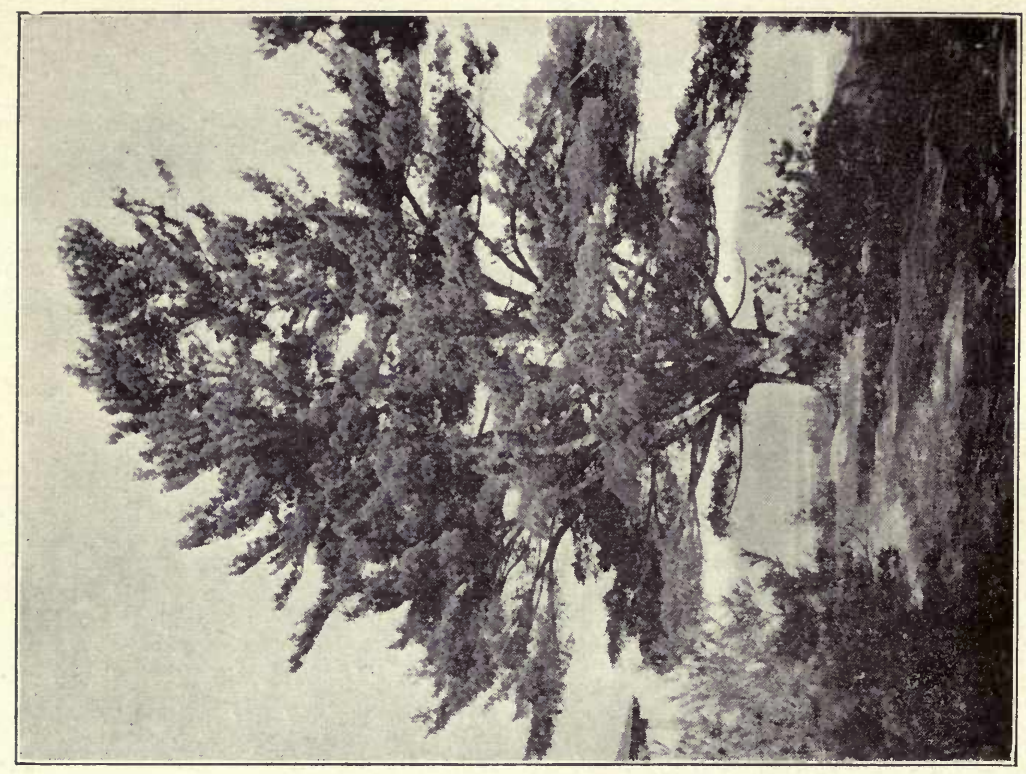

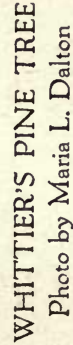

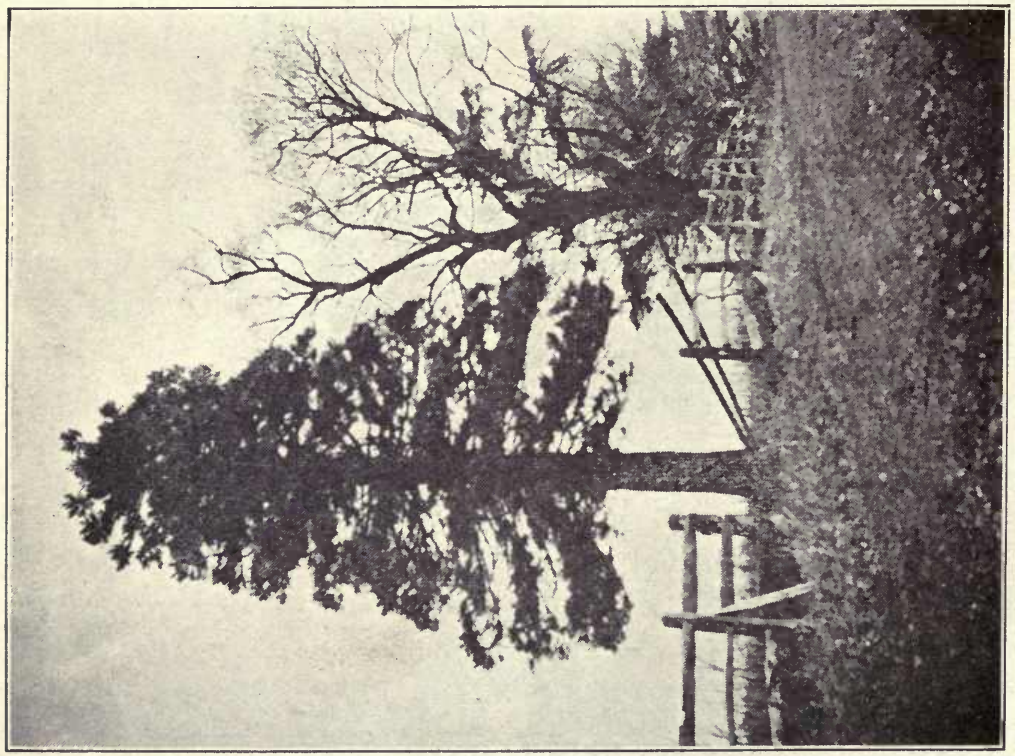

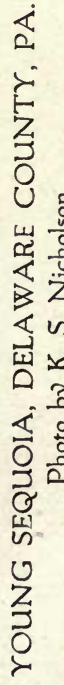




\section{CHAPTER XIV}

\section{The Jane McCrea Pine-Abolition Grove-Holmes and Whittier Pines-The Kit Carson Tree-The McKinley Tree-The Sequoias, Big Trees and Redrooods.}

\section{The Jane McCrea Pine}

A pine tree, that witnessed the tragic death of Jane McCrea, stood at Sandy Hill, in New York State. The young girl, who was engaged to marry David Jones, an officer in Peters' Regiment of Loyalists, set out to meet her lover at his brother's home, in the neighborhood of General Frazer's camp, escorted by two Indians, one of whom was the Huron Chief, Wyandotte Panther.

A keg of rum had been promised the two savages if she were delivered in safety at her destination, but on the way, they began quarreling over the reward, and in order to prevent his companion from enjoying any of it, Wyandotte Panther scalped the maiden under the pine tree. The crime was committed on June 27 th the day before Burgoyne broke camp at Fort Edward. The massacre filled the countryside with horror.

\section{Abolition Grove}

The white pine, with its smooth bark and soft, bluish-green tassels, is the most beautiful of its family, and also invested with much historic interest. The splendid group of white pines at Abington, Mass., known as Island Grove, or more frequently as Abolition Grove, has been called "the place where the Civil War began." Here, noted men and women frequently made eloquent speeches advocating the abolition of slavery. Webster and Garrison were both among the many speakers, adding their efforts to prove "that slavery can only be overthrown by adherence to principle." Meetings of the abolitionists were held in the grove, annually, from 1846 to 1865. A great boulder, bearing a copper plate with a long inscription, designates the spot where the speakers stood.

\section{Holmes and Whittier Pines}

Two white pines, one in Massachusetts, the other in New Hampshire, were ardently venerated and loved by two of our best known American poets. 'The splendid specimen at Pittsfield, Mass., noted as the Oliver Wendell Holmes Pines, is ninety-seven feet in height, and its branches cast their shade over an area of almost ninety feet.

"Whittier's Pine Tree," which the Quaker poet dedicated in 1886, as the "Wood Giant," stands on the Sturtevant Farm, near Sunset Hill, Centre Harbor, N. H. 
"Among the scattered groups of pines," says Agnes L. Scott, describing the venerable tree, "Whittier's tree stands compact, like a silent patriarch, with a splendor all its own. Its chief characteristic is its magnificent strength, enormous trunk and powerful boughs that give it the appearance of a giant." Every day, it was the poet's custom to walk to the great pine and watch the sunrise from beneath its branches.

"Here he saw to the East the Cardigan Mountains; to the North, the Sandwich Range; to the West, the Ossipie Range; and here he saw the beautiful broad view of Squaw Lake with its green wooded islands."

\section{The Kit Carson Tree}

The Native Sons of California have erected a monument marking the site of the pine on which Kit Carson carved his name, in 1844, when acting as a guide to Colonel Fremont. It was on this trip that the Colonel discovered Lake Tahoe. The pine, which stood in a pass in the Sierra Nevada Mountains, was cut down in 1888. A full account of its history has been placed in the monument.

\section{The McKinley Tree}

The tall, spreading pine on the Hotel Champlain Golf Course gained its fame as the favorite resting-place of the late President William McKinley, during a summer visit to the hotel at Bluff Point, when he made the Hotel Champlain the "summer capitol." A remarkable coincidence, which further distinguished the tree, was that on the very day on which the President was assassinated, the pine was struck by lightning and its upper part broken off.

\section{The Sequoias, Big Trees and Redwoods}

Once abundant over the whole of the northern hemisphere, in Europe, Siberia, Alaska, Greenland and Canada, as well as in America, the Sequoias are now represented by only two species, both natives of California; S. gigantea, the Big Tree, and S. sempervirens, the Redwood of the Coast Range. They are universally conceded to be the oldest living things on earth, the age of those which have been cut, averaging from eleven hundred to three thousand, two hundred and fifty years, while the two known as the Grizzly Giant and the General Sherman Tree are estimated to be of far greater age. In height the Big Trees vary from one hundred and fifty to two hundred and twenty-five feet, and naturalists have calculated, that, judging from the tapering of the trunk, they would normally have reached six hundred feet, if left unmolested by wind and fire. In circumference they average from five to twenty-five feet at shoulder height above ground. Many attain - a much greater size, and the famous General Sherman Tree measures one hundred and three feet around the trunk.

"How old the oldest trees may be is not yet certain," says Dr. Ellsworth Huntington, of the Department of Geography, Yale Uni- 
versity. "But I have counted the rings of forty that were over two thousand years of age, of three that were over three thousand and of one that was three thousand one hundred and fifty."

The first white man to have a glimpse of these forest giants was probably General John Bidwell of California, who arrived in 1841, with a party of emigrants. Reporting the marvelous trees to General Fremont, he found his story scorned. A similar reception awaited Mr. Dowd, a hunter who is said to have found himself in the Calaveras Grove, and was, naturally, lost in wonder at what he saw. Returning to his companions, at their camp, his story was ridiculed. Shortly afterward, while hunting, he succeeded in guiding them into the grove, and letting them see for themselves.

The Big Trees now became known far and wide. Cones and leaves were shipped to Gary and Torrey, the botanists, but were lost on the voyage. It remained for a British naturalist, William Lobb, to transplant specimens to England, and for Dr. Lindley of London to record the tree as a new genus and name it after the Iron Duke, Wellingtonia Gigantea. The Redwoods had already been known to scientists for many years, however, and had been classified under the name of Sequoia. Decaisne, a French botanist, decided that the Big Tree was unquestionably another member of the same genus, and christened it Sequoia Gigantea, by which name we know it today.

An American, Dr. C. E. Winslow, becoming jealous for the fame of his own country, soon afterward published a letter, dated August 8, 1854, in the "California Farmer," urging that the Big Trees should logically be named for Washington, Washingtonia Californica. But though some writers have adhered to this name, it was never adopted by botanists. The name Sequoia, it may be added, which had already been bestowed upon the Redwoods, was given in honors of the noted Cherokee, Sequoyah, who invented the first alphabet ever used by the Indians. The perpetuation of his name in this way was considered an act of poetic justice on the part of the United States Government.

The Redwoods of the Coast Range live only about half as long as the average Big Tree, generally from five hundred to one thousand three hundred years, probably somewhat longer. Their circumference is usually sixteen feet, though the largest known measures thirtythree feet, and their height varies from one hundred to three hundred and forty feet. As the Redwood is an evergreen its name, sempervirens, is well given. It has been described as a "beautiful, cheerful and very brave tree. Burned and hacked and butchered, it sprouts up again with a vitality truly amazing. It is the marvelous capacity for new growth from trunk or from root saplings, which is perhaps the most interesting character of the Redwood in contrast with the Big Tree, which has no such means of regeneration and must depend on its cones for reproduction."

It was in October, 1769, that the Redwoods were first seen by white men. An entry of that date in the diary of Padré Crespi, a 
Spanish missionary, mentions seeing them, near where the town of Santa Cruz, Cal., now stands. As such trees were entirely new to him and his party, they received a Spanish name meaning red, from the color of the wood.

Unfortunately, redwood timber has been found to be of excellent quality. A forest of these trees will yield from one hundred thousand to one million feet of timber. Incredible as it seems it has been found necessary to protect these giant forests, both of Redwoods and Big Trees from the lumberman's axe. "It is scarcely necessary to dwell on the crime involved in the destruction of the oldest and tallest trees on earth," says Madison Grant.

"The cutting of a Sequoia for grape-stakes or railroad ties . . . is like breaking up one's grandfather's clock for kindling to save the trouble of splitting logs at the wood pile, or lighting one's pipe with a Greek manuscript to save the trouble of reaching for matches."

Thanks to the efforts of the "Save the Redwoods League," which began its work in 1917, much has been done to rouse public sentiment on the question, and to pave the way for establishing a Redwood Park. America is greatly indebted to the National Geographical Society for its co-operation with the Government in presenting to the people for a park the Giant Forest of Big Trees which is the largest body of trees of this kind in existence, and one of Nature's greatest marvels.

One of the few Sequoias east of the Rocky Mountains, and probably the only one of its age in the east, grows by the roadside in a field in Delaware County, Penn., about twenty miles from Philadelphia.

The tree is a true Sequoia Gigantea, but it is a mere infant of its species, being probably between seventy-five and eighty years of age, and was brought from California to one of the early botanists of Pennsylvania, about the year 1850. Thirty-five feet in height and with a circumference of two feet, it has a long life in prospect, provided it can withstand the occasional severity of eastern winters. About half a mile distant, in the historic old botanic garden known as Painters' Arboretum and formerly owned by the brothers Jacob and Minshall Painter, is another Sequoia, S. sempervirens. This is a Redwood, said to be the only survivor of six of its kind, which were also brought from the Pacific coast, two of them for the Painters, and the remainder for two other botanists, Evans and Meehan. 


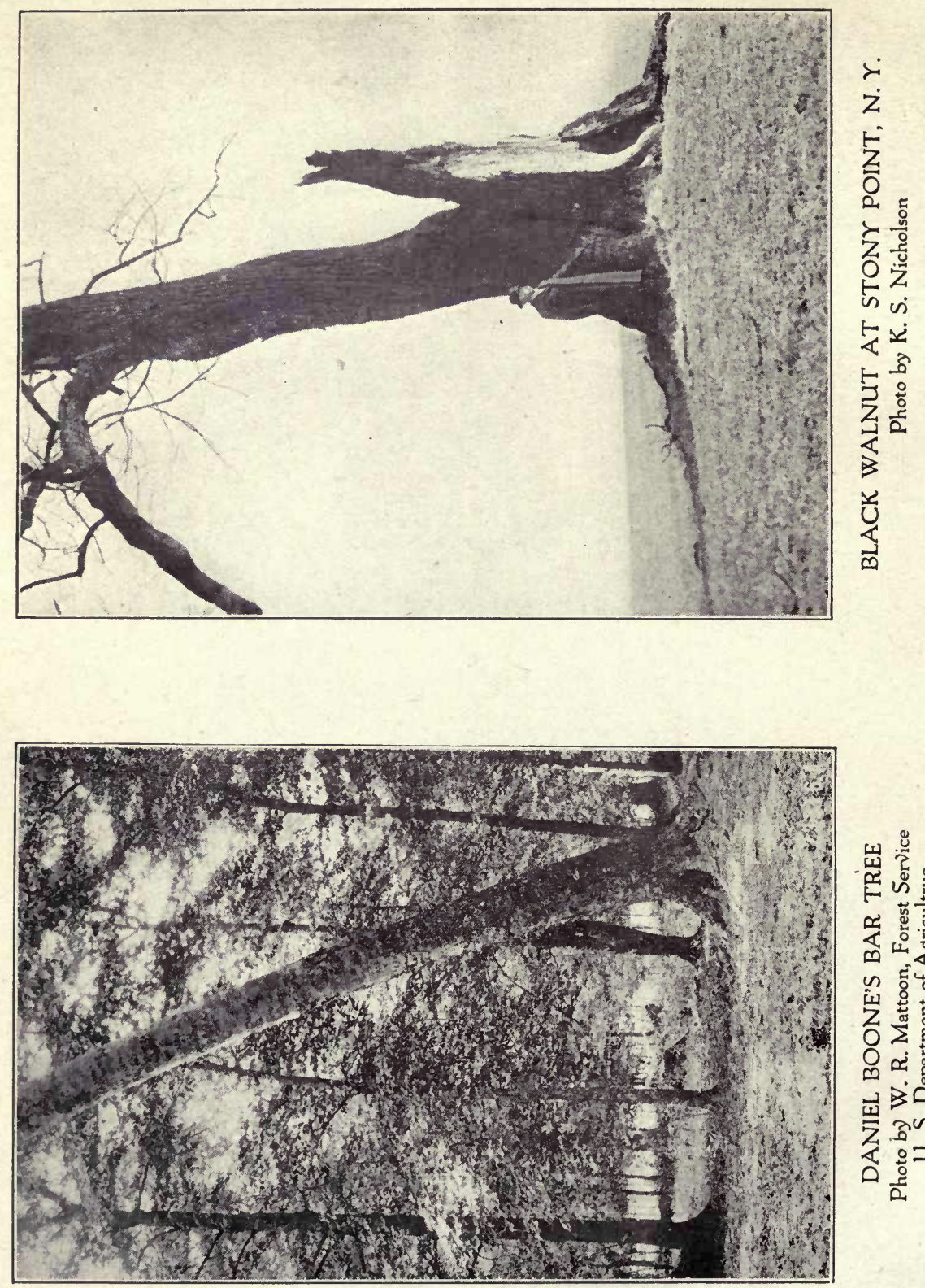

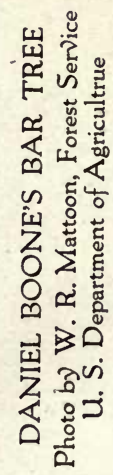




\section{CHAPTER XV}

\section{Daniel Boone's "Bar Tree"-Beech of Great Cloud Island-A Beech of Milwaukee-Beeches of Camp Robinson-Origin of Weeping Beeches-Black Walnut of Stony Point-Whipping Tree of Fish- kill-Black Walnut of Maplewood-Walnut Beside Washington's Tomb-The Treaty Tree of Philipse Manor.}

\section{Daniel Boone's "Bar Tree"}

At Cumberland Gap, the famous mountain pass near the borders of Tennessee and Kentucky, is a tablet, placed there by the Tennessee Daughters of the Revolution, and bearing these words: "Daniel Boone's Trail from North Carolina to Kentucky, 1769."

Nearby, on the bank of Carroll Creek which flows into the Watauga River, is an immense beech known as "Daniel Boone's Bar Tree," from the inscription cut in the bark, "D Boone cill E D A B A R On tree in the Y E A R 1760." The trunk of the beech measures twenty-eight and one-half feet around, at a distance of four and one-half feet from the ground, and its height would equal eightyfive feet if it stood erect; it leans south, however, at an angle of thirty degrees. The United States Forest Service has estimated its age at from three hundred and forty to three hundred and sixty years.

The Forest Examiner, Mr. Wilbur R. Mattoon, describes the tree as "a living record of an event in the life of probably the first white man to venture into the heavy forests formerly covering the western slopes of the middle Appalachians." Inhabitants of the region told Mr. Mattoon that the original inscreption was legible as late as from 1875 to 1885 , a surprisingly long period for it to endure. The figures 1815 carved also on the trunk can still be clearly read, but we have no record of the event to which they refer.

\section{Beech of Great Cloud Island}

The only beech tree ever known to grow within the borders of Minnesota, stood on Great Cloud Island, in the Mississippi River, between St. Paul and Hastings. It is mentioned in the journal kept by Major Thomas Forsythe, a member of Colonel Leavenworth's expedition of 1819, which was sent out for the purpose of establishing Fort Snelling. The Indians called the tree "Medicine Wood," signifying "simply miraculous or wonderful tree."

Forsythe comments on it was follows: "Medicine Wood takes its name from a large beech tree, which kind of wood the Sioux are not acquainted with, and supposing that the Great Spirit has placed it there as a genii to protect or punish them according to their merits or demerits." 


\section{A Beech of Milwaukee}

Another historic beech stood, some years ago, near the corner of 13th and Wells Streets, Milwaukee, Wis., and was evidently a relic of very early times. Upon its trunk was carved the figure of an Indian holding in one hand an arrow pointing toward the Menominee River, in the other hand a bow pointing toward the Milwaukee. The tree is no longer standing, and its loss is much to be regretted.

\section{BeEches of Camp Robinson}

Standing in Riverside Park, Indianapolis, Ind., a handsome grove of beech trees recalls the days of the Civil War. Nearly sixty years ago, the grove was known as Camp Robinson, the spot selected by General Wallace, (widely known as the author of "Ben-Hur"), as the rendezvous of the Eleventh Indian regiment while it was being fitted for service.

The trees occupy an elevation above White River, and when the camp was established there, the surrounding country was heavily wooded, an ideal place for concentration upon the task in hand. Some of the spare time of the soldiers was spent in carving names and initials on the beech trunks, and during the long years that have followed, the bark has grown over the letters in such a way that they stand out as if embossed, and are more clearly legible today than when they were cut.

\section{Origin of Weeping Beeches}

On the Jackson Place at Flushing, N. Y., is a magnificent weeping beech to which is attached an interesting bit of history. Over a century ago, Baron De Mar, a Belgian noble, was watching the transplanting, on his estate in Belgium, of several European beech trees. Noticing one whose branches were hanging so that it appeared almost deformed, he directed the gardener to throw it out. The latter, however, considered the odd looking specimen worth attention, and proceeded to care for it until it repaid his efforts by developing into the graceful tree, that is now known as the drooping or weeping beech. When Baron De Mar saw the novel specimen he was delighted, and shoots from it were sent to his friends in France.

In 1847, Samuel B. Parsons, a nurseryman of Flushing, while traveling in Europe in search of unusual plants, purchased a descendant of the De Mar beech. He planted it in a flower pot and brought it back to Flushing as part of his personal luggage. There it grew and matured into the beautiful tree that stands at present on the Jackson Place, in all probability the first weeping beech of America.

\section{Black Walnut of Stony Point}

Occupying literally, "the centre of the stage," with no companion near, to bear an equal share in dignity of years or of historic associa- 
tions, an ancient black walnut near the town of Stony Point, N. Y., is the sole surviving witness of events connected with the memorable battle of Stony Point.

On the bank of the Hudson River, rises the Point, a "defiant promontory with rocky and wooded faces ... fittingly described as a natural sentinel guarding the gateway of the far-famed Highlands of the Hudson." About one hundred and fifty feet at its highest point, it juts out into the river half a mile from shore; on the inland side is marshy ground, which at the time of the Revolution was deep and treacherous. No wonder that such a natural fortress was called "little Gibraltar." And no wonder the British troops felt secure in such a stronghold.

The belief has been handed down among the residents of Stony Point, that under the old walnut tree Washington paid the men after the battle. There seems no reason to doubt the statement; certainly not on the question of age, for the tree was undeniably there at the time, and when intact, its branches must have cast a breadth of shade that would have rendered the spot most fitting for the occasion. For the assault took place during July, and no doubt the sun of midsummer beat down as relentlessly in 1780, as at present.

Four feet above the ground, the massive trunk measures twentyone feet in circumference, and four feet further up, it divides into two parts, rising to a height of approximately eighty feet. Subject by its exposed position to a severe sweep of the wind, the southern fork has been torn away, and this veritable monarch of the countryside stands pathetically shorn of its former glory.

It is much to be regretted that no adequate attempt has been made to preserve this natural monument of a stirring page in our country's history.

\section{Whipping Tree of Fishkill}

On the east side of the Hudson, on the old Albany Post Road, two miles south of the village of Fishkill, N. Y., stood, until about a dozen years ago, a black walnut, used during the Revolution as a whipping tree. It was the custom, when punishing offenders beneath such trees, to fasten them by their thumbs to iron spikes or nails driven into the trunk. It was, of course, a foregone conclusion that this must have been done in the case of this black walnut, but in later years no traces of the metal were visible. When, however, the old tree finally lay prone on the ground, and was chopped into firewood, the axe met an obstruction, and investigation brought to light the iron collar, driven full of huge nails, that had partly encircled the trunk, and over which, in the course of time, the bark had grown, entirely covering it.

The field in which the whipping tree stood was a camping ground of the American troops. while almost opposite, across the road, is the old Wharton homestead, used as headquarters by their officers, and 
also famous as the scene of many episodes in Cooper's novel, "The Spy."

\section{Black Walnut of Maplewood}

The large, spreading black walnut still standing in front of Timothy Ball's house at Maplewood, N. J., was planted in 1743, the year that the house was built. A magnificent shade tree, and still bearing a plentiful crop of nuts, it is rich in historic association. The Balls were Washington's cousins, and the General often visited them, and tied his horse to an iron ring in the trunk of the walnut. Old people, still living, remember when the ring was visible, though now it is doubtless hidden by the growth of the trunk around it.

The old tree also served another purpose; it stood about half-way between two Presbyterian churches, and was considered to mark the dividing line between them. Residents to the north of it were expected to attend the Orange church, those living south the Springfield church.

\section{Walnut Beside Washington's Tomb}

This tree, planted by George Washington's father, and in the shade of which the first President of the United States was buried, became conspicuous on account of a large burl or knot on its trunk, measuring five feet through, and probably one hundred years old, when removed and sent to the National Museum at Washington, D. C.

\section{The Treaty Tree of Philipse Manor}

Many historical and literary associations cluster about the beautiful tract of country on the east bank of the Hudson, once known as Philipse Manor, N. Y.

At least a portion of it is said to be one of the last grants of land in America signed by William and Mary of England. In 1672, Frederick Philipse purchased a large share of it, originally in the possession of de Jonkheer Adrian Van der Donck, the future site of the town of Yonkers, N. Y., and then proceeded to add to his property until it included thousands of acres of forest, field and hill. His fine estate has been described as "virtually a barony under the management and sway of the masterful proprietor."

In 1682, "the Dutch Millionaire" as he was dubbed, built his manor-house near New York City, and later erected "Castle Philipse," at Sleepy Hollow in Tarrytown, N. Y. Both residences were handsomely furnished, and the grounds surrounding them were beautified with imported shrubbery and flowers. Near the "castle" stands a memento of those early days, of equal, if not greater interest than even the homestead.

This is the well known "Treaty Tree," a huge chestnut, measuring over twenty feet in circumference. Though the last sign of life has departed from its leafless branches, the ancient tree has not been 
felled, but is carefully preserved by the Philipse Manor Company, vines having been planted at its base, and having grown and twined themselves pityingly around the gaunt trunk and limbs until they have rendered the former monarch of the forest once more a thing of beauty. Under the old chestnut, it is believed, was signed the last treaty made between the whites and the Wequadequeek Indians who lived in that region.

It is told (and is quite possible) that under its shade, also, Washington Irving wrote his tale of the "Headless Horseman," whose favorite resort, it will be remembered, was the neighborhood of Old Sleepy Hollow Bridge. A short distance away, Irving's former residence "Sunnyside" is situated, only a ten or fifteen minutes trip from the tree, if one happens to be motoring.

The ancient chestnut stands on the Philipse Manor property and is in plain sight from Broadway, the Albany Post Road. 


\section{CHAPTER XVI}

\section{The "Old Washington Tree"-The "Big Chestnut Tree" of Valley Cottage-The Cedarcroft Chestnut-Indian Trails and Trail Trees.}

\section{The "Old Washington Tree"}

The spreading chestnut tree at New Hope, Penn., long known as the "Old Washington Tree," was not only directly associated with the Father of his Country, but also marked a spot of great strategic importance in the struggle for American Independence.

Coryell's Ferry at New Hope, was the best ferry on the Delaware River north of Trenton, N. J., and both the British and American armies were desirous of controlling it, the former failing more than once to effect a crossing from New Jersey to the Pennsy]vania shore.

During December, 1776, a large part of the Continental Army was encamped at New Hope. A month previous, Washington had evacuated Fort Lee on the Hudson, opposite New York City, and retreated across New Jersey to Trenton, where, there is little doubt Cornwallis confidently expected to find the Americans an easy prey on account of the difficulty of escaping across the Delaware.

Thanks, however, to the patriotic efforts of two young men, Jerry Black and Daniel Bray (later known as General Bray), who were acquainted with every boatman on the river, a large enough fleet was secured to carry the Continental troops safely across, at the historic point just above the present town of Taylorsville, N. J., known to history as "Washington's Crossing."

"Coryell's Ferry" on the Pennsylvania shore, now became a busy. military centre.

"Within the limits of this ancient borough," says Richard Randolph Parry, "the eye rested everywhere upon the valley, hillside and fields dotted with the tents of the Continental soldiers. At the Neeley (Thompson) farmhouse were quartered Lieut. James Monroe, afterward President of the United States, and other officers. Nearby at 'Chapman's' were General Knox and Captain Alexander Hamilton." General Greene was at a neighboring farmhouse, and General Sullivan only a short distance away. General Washington's headquarters were at the Keith farm.

The "Old Washington Tree" stood in a field opposite General De Fernoy's and Lord Stirling's headquarters, and under its branches, Washington and his Generals, Knox, Sullivan, Greene and Stirling, first discussed plans for the Battle of Trenton which was so soon to occur. 
Again, in 1778, when Coryell's Ferry, as well as the other crossings of the Delaware, were held in security by American troops, Washington and his staff rested at noonday in the shade of the big chestnut, when on their way to attack General Clinton's army at Monmouth, N. J.

On November 28, 1893, the old tree was cut down, to make room for improvements. Near the spot which it graced there is an old stone house once owned by Captain Edward F. Randolph, a "patriot of 1776," who gave his services to his country, refusing to accept any remuneration for his distinguished military service.

\section{The "Big Chestnut Tree" of Valley Cottage}

Valley Cottage, N. Y., possesses an interesting relic of Revolutionary times, in the shape of an old chestnut stump which stands thirty feet high. In its prime, the tree reached a height of about fifty-five feet. At its base, the stump measures nineteen feet, eight inches in circumference, an important item considering its part in history.

The chestnut was owned by a Tory who was known to be bitterly opposed to the American cause. The Whigs, coming to arrest him, one day, were unable to find any trace of his whereabouts, when suddenly their search was rewarded in a most unexpected fashion. His pet calf, who was noted for following its master everywhere, was seen to station itself beneath the tree, and began bleating loudly. Its master, hidden in the hollow trunk, was quickly seized and made prisoner. What became of his pet, the innocent cause of his capture, has not been recorded.

\section{The Cedarcroft Chestnut}

"When I build a house," Bayard Taylor, the well known author, said in his youth, "I shall build it upon the ridge, with a high steeple from the top of which I can see far and wide." Cedarcroft, the home that he did construct, later in life, at Kennet Square, Penn., not only fulfilled this requirement, but was also happy in a wealth of fine old trees, both cedars and mighty forest trees of various sorts. Taylor used to say that not even the oaks of Charlecote Park, where young Shakespeare occasionally trespassed, could equal the trees of Cedarcroft.

One in particular, a splendid old chestnut, was a favorite rendezvous for himself and his literary friends. Sidney Lanier, the poet, a welcome visitor at Taylor's home, and an evident lover of nature, was much attached to the ancient tree, and immortalized it as a valued companion, in his graceful poem, "Ūnder the Cedarcroft Chestnut."

\footnotetext{
"A Presence large, a grave and steadfast form Amid the leaves' light play and fantasy,

A calmness conquered cut of many a storm,

A Manhood mastered by a chestnut tree!
} 
How Life in truth was sharply set with ills;

A kernel cased in quarrels yea, a sphere

Of stings, and hedge-hog-round of mortal quills.

How most men itched to eat too soon i' the year,

And took but wounds and worries for their pains,

Whereas the wise withheld their patient hands,

Nor plucked green pleasures till the suns and rains

And seasonable ripenings burst all bands.

And opened wide the liberal burrs of life,

There, $0 \mathrm{my}$ Friend, beneath the chestnut bough,

Gazing on thee immerged in modern strife,

I framed a prayer of fervency that thou,

In soul and stature larger than thy kind,

Still more to this strong form might'st liken thee

Till thy whole Self in every fibre find

The tranquil lordship of thy chestnut tree."

\section{Indian Trails and Trail Trees}

Long before the first white settlers had found their way to North America, the native Indians had covered the continent with a network of highways or trails over which they traveled great distances with incredible swiftness.

The Santa $\mathrm{Fe}$ and Oregon trails were much used routes, both starting at Independence, Mo., and terminating, one in New Mexico, the other near the Willamette River, Ore. Another trail led from Montreal, Canada, down the Ottawa River to Lake Huron and Green Bay, Wis., and still another ran in a different direction from Montreal through Lake Champlain into Lake George, and connected by a portage with the Hudson River in New York State.

Albany on the Hudson was connected by a trail with Rochester and Buffalo, N. Y., on the Great Lakes. A trail known as the "trading path" began at Richmond, Va., and the famous "Warriors' Path" linked Cumberland Gap, on the borders of. Tennessee and Kentucky with the mouth of the Scioto River, in Ohio. Another trail running from Philadelphia to Kentucky by Cumberland Gap extended nearly eight hundred miles.

As the Indians were accustomed to marching in single file, their roads were narrow, those in the eastern part of the country rarely exceeding eighteen inches in width. After the coming of the white men, the trails were constantly traveled by them as well as by the Indian traders, hunters and war-parties, since it was easier to follow already beaten tracks than to blaze their own. It is an interesting fact that most of the railroads in New York State, as probably elsewhere, follow pretty nearly the route of the old trails.

The Indians are said to have marked their trails by certain signs either natural or artificial for the sake of convenience. 
There is a tradition in the Alleghenies of Pennsylvania, that slabs of rock which have been found in an upright position, were used to mark trails there. In other localities, it is thought that the various trees whose limbs appear to have been forced into abnormal positions in such a way as to attract attention, were intended by the red men to serve as guide posts along their narrow and often tortuous ways.

A good example of these "Indian Trail Trees" as they are called, is the tall hickory at Madison, Wis., (on Cover) on the route of an old trail, one of whose branches is conspicuously bent into a horizontal position as if to indicate a certain direction. Another trail tree at County Line, Glencoe, Ill., by the side of the railroad, has an odd appearance; perhaps fifteen feet above ground level its trunk is bent downward to the earth and then upward again, forming a sharp elbow, a few feet above which it forks and then continues up, its leafy branches rising to a good height. Whether intentionally bent into this position or owing it to a freak of nature, such a tree would of course constitute a guide-post not easily overlooked or forgotten.

"There are at various places along the North Shore (of Lake Michigan) and following closely the line of several of the old Indian trails some curious trees that apparently have been broken, or rather bent and tied down with saplings by Indians to mark these trails," says Frank E. Grover of the Chicago Historical Society. "That custom has been followed in other localities, among which, it is said, is the Braddock Trail, several localities near Fox Lake, Ill., also in the vicinity of Mackinac, Mich., and it is entirely probably here. The trees are invariably large and, if this convenient and plausible theory is correct, some of this work of so marking the trails must have been done a century and more ago, for many of the trees are white oaks of considerable size. These trees and this theory present also a most interesting field for inquiry and speculation.

"But some six years ago, there were eleven of these trees in perfect alignment, leading from the site of the old Indian village at Highland Park, Ill., in a northwesterly direction for several miles, most of them are still standing and can be easily identified, and what is particularly of interest is the fact that all of these trees are white oaks, while another line of similar trees supposed to mark another old trail farther to the south, near Willamette, Ill., are without exception, white elms, indicating system in the selection. These in the City of Evanston, Ill., were oaks and supposed by the supporters of this theory to lead to the chipping stations or shops on the lake shore. Two or three of these trees were also located on the North branch of the Chicago River, Ill., near the Glen View Golf Club, probably marking the trail to one of the nearby villages. Another circumstance that gives color to this contention is that where those trees were found was once a dense and heavy forest, where it is probable that an Indian trail would be marked, if marked at all." 


\section{CHAPTER XVII}

\section{The old Mulberry of St. Mary's-The Harris Mulberry-Some Early Attempts at Silk Culture-Mulberries of Mt. Vernon-Mulberry Farm-Mulberries of McSherrystown.}

\section{The Old Mulberry of St. Mary's}

In February, 1634, two ships, the Ark and the Dove, carrying English colonists, anchored in the Potomac River at an island about half a mile from the Maryland shore.

Delighted at the wooded bluffs and green islands they had passed, the passengers had amused themselves by giving names to the various points as it pleased their fancy, and called the island where they now landed, St. Clement's. It is known today as Blakiston's Island.

Leonard Calvert, leader of the expedition, continued his journey farther up the beautiful river, in order to interview the chiefs of the various tribes and satisfy them that his intentions were friendly. Happily for all concerned, he met a fur-trader, Captain Henry Fleet, whose intimate knowledge of the surrounding country served the strangers well. As they objected to settling far from the sea, he guided them to a smaller river flowing into the Potomac, to which they gave the name of St. George's, calling one of the two harbors formed at its mouth, Saint Mary's, by which name the little river became, known later.

Following the smaller stream, they landed at a bluff, and half a mile farther inland, Captain Fleet introduced them to his friends of the Indian village of Yaocomico.

On the bluff, overlooking the water, its great size causing it to be visible for a considerable distance up and down the river, was the immense tree afterward known as the Old Mulberry, a landmark intimately associated with the history of the colonists of the little town of St. Mary's, the first capital of Maryland.

"Well authenticated tradition," - which is closely akin to actual history-tells us that under the mulberry's shade, Calvert made a treaty with the Yaocomicos, exchanging with them "mutual promises to each other to live friendly and peacably together, and if any injury should happen to be done on either part, that satisfaction should be made for the same." And the compact was faithfully kept, all working happily together, busily planting and building, the whites sharing the redmen's village, and eventually purchasing the land from them. As raids by the powerful Susquehannocks were becoming very troublesome, the Indians consented readily to this arrangement, and willingly moved to other quarters. Almost immediately, the political history of the little State began. The First General Assembly of 


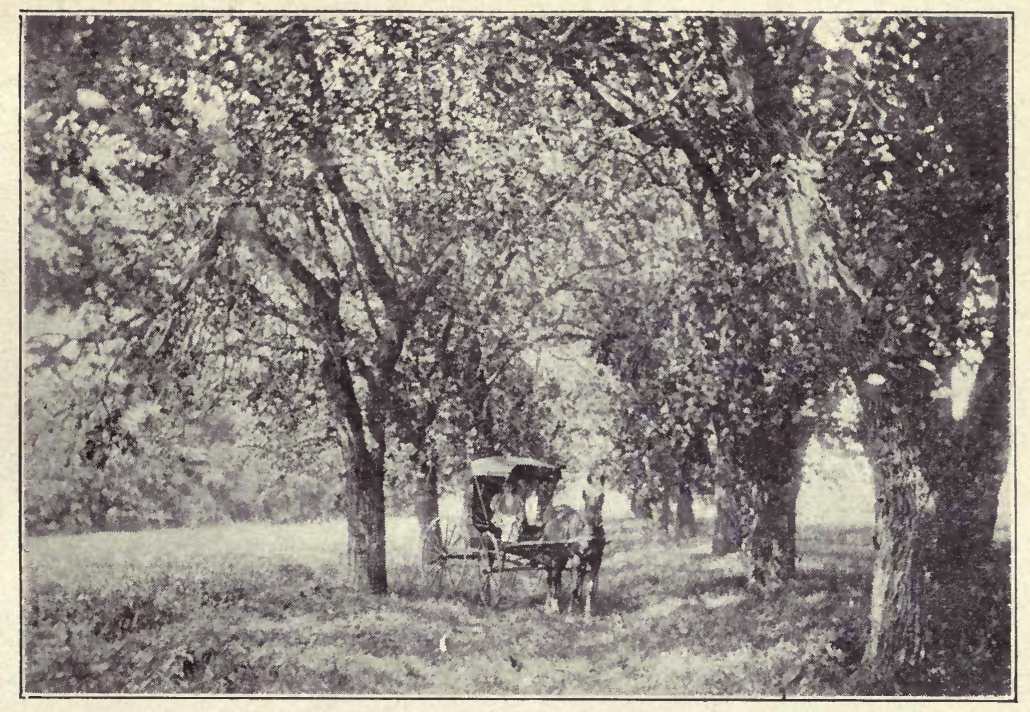

\section{MULBERRY WALK}

Planted by Count Du Barry. Courtesy of Mrs. Frederick Winslow Taylor.

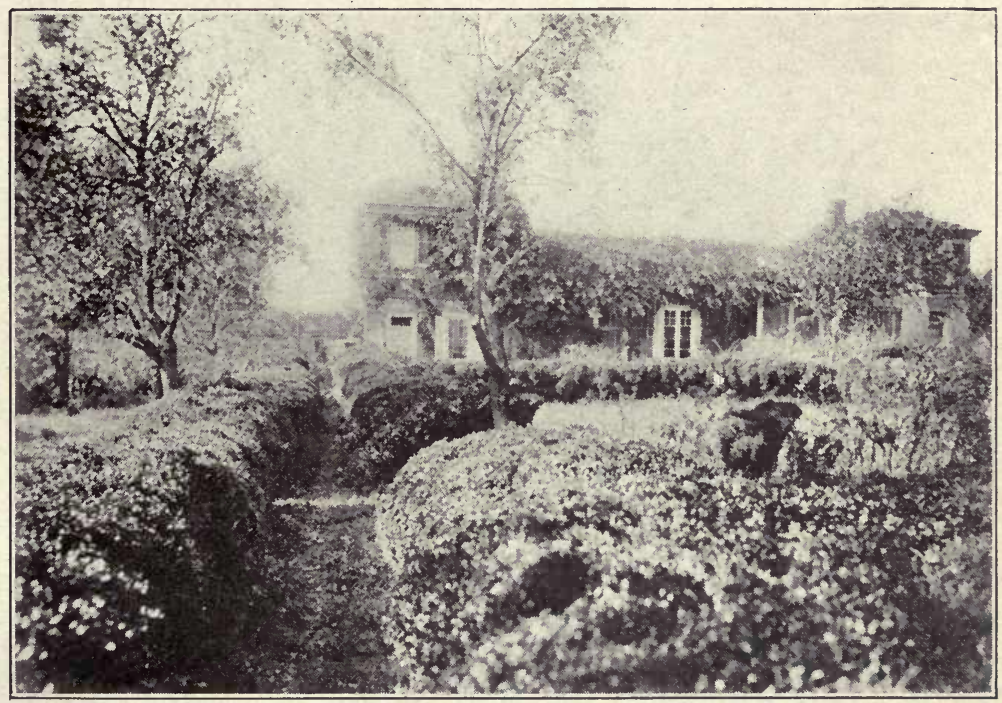

Sections of box planted by Count Du Barry, and buildings erected by him for boiling cocoons. Courtesy of Mrs. Frederick W. Taylor. 

Maryland was convened at Saint Mary's on February 26, 1635, meeting, it is said, under the Old Mulberry. Under its branches, also, the first Mass is believed to have been celebrated by the little community. The historic tree became a centre of popular interest in the village; on its trunk were nailed Governor Calvert's proclamations and those of his successors; as well as "notices of punishment and fines, the inventories of debtors whose goods were to be sold and all notices calling for the public attention." In comparatively recent years, the "rude nails" which had fastened these documents to the tree, were still to be seen in the wood.

About seventy feet distant from the tree, the State House was built, and for sixty-one years the little capital flourished. Not all was harmony, for Lord Baltimore refused, at first, to approve the Acts of the Assembly, holding that under the charter of Maryland he alone had power to make laws. In return, at their next session, the colonists rejected all his bills and passed their own. After this, their rights were not again questioned, and in 1637, they became in reality a self-governing body.

Political freedom having been established, religious liberty was also guaranteed in the famous "Toleration Act" passed in 1649, which has been styled the "proudest memorial by colonial Maryland." Within the old State House, says Dr. James Walter Thomas, the historian, were laid "to a great extent the foundations and outlines of the present legal, civil and social structure of Maryland, and of some of its most cherished institutions."

In 1691, Saint Mary's was placed under Royal Government and the Church of England established there. In 1694, Anne-Arundeltown or Annapolis was proclaimed State Capital, partly on the plea that Saint Mary's was not sufficiently accessible.

In vain, did the inhabitants offer to maintain a coach and six horses for "riding post," between Saint Mary's and Pawtunxet, during the sessions of the Legislature. The history of the town was virtually finished, and gradually the place became, indeed, a deserted village.

It is interesting to note, in passing, that the Pawtunxet road, leading to Annapois, is still known as the "Three Notched Road," due to the fact that by order of the Assembly of 1704, it as well as other highways, were distinguished by notches cut in the trees, and the Pawtunxet main road was marked by three such cuts, some of which are still visible.

The usefulness of the Old Mulberry did not all vanish with the fall of its little city. It yielded some of its wood for furniture to be used in the Episcopal Church later built there, and some for the making of souvenirs sold for the benefit of the same Church. Living through parts of at least three centuries, and witnessing some of the most interesting scenes of colonial history and much that was of vast importance to future generations in its own State, the veteran Mulberry fell in 1876, sincerely mourned by many who had learned to 
love and reverence the ancient tree. On the spot where it cast its dense shade for so long a period, stands a handsome monument bearing the following inscription:

"To the Memory of Leonard Calvert

First Governor of Maryland,

This Monument is

Erected by

THE STATE OF MARYLAND.

ERECTED ON THE SITE OF THE

OLD MULBERRY TREE

Under which the First Colonists of Maryland assembled To Establish a Government where the persecuted and oppressed of every creed and every clime might repose in peace and security, adore their common God, and enjoy the priceless blessings of civil and religious liberty.

\section{Leonard Calvert}

Second Son of George Calvert

and Anne, His Wife,

Led the First Colonists to Maryland

November 22, 1633-March 3, 1634-Founded Saint Mary's

March 27, 1634."

\section{The Harris Mulberry}

Until 1884, when it was uprooted by a flood, a mulberry tree sacred to the memory of John Harris, founder of Harrisburg, Penn., stood at the foot of Washington Street, in that city.

Harris was one of the emigrants who came to this country with William Penn, possessing at that time sixteen guineas as his entire capital. Settling in Philadelphia, he began work as a contractor, cleaning the streets of stumps and opening new thoroughfares.

Opening trade with the Indians, he traveled as far as the present site of Harrisburg, and began a settlement there about 1719.

It happened, one day, that a number of Indians stopped at the Harris home, most of the party being under the influence of liquor, and demanded more rum. Upon Mr. Harris' refusal, they bound him to the mulberry tree and warned him to prepare for death. Piling dry wood at his feet, they were about to apply a torch, when Hercules, his negro slave, summoned a band of friendly Indians to the rescue. Harris' life was saved, and as an expression of gratitude he gave Hercules his freedom.

In later years, an inscription commemorating Harris' narrow escape was placed upon the tree. 
The establishment of the silk industry in America was urged early in the history of the colonies, mulberry trees being plentiful and furnishing a ready supply of food for silk worms.

In 1725, James I Logan, William Penn's secretary, wrote to the Penn family, speaking of the culture of silk in America "as extremely beneficial and promising." In 1734, Governor Gordon, of Pennsylvania, addressing the Lords Commissioners of Trade, on various subjects, spoke of the good returns that might be expected from silk culture, mulberry trees being native to American soil.

The year 1770 saw the subject taken up in Philadelphia, Penn., and the surrounding country, with great interest. For this the American Philosophical Society (Philadelphia) was largely responsible, influenced, of course, by letters from Dr. Benjamin Franklin who was at that time abroad.

Application was made to the Colonial Assembly for the establishment of a "public filature at Philadelphia for winding cocoons, and the managers to have power to grant premiums, etc., equal to about $£ 500$ per annum for five years." Necessary funds were raised by private subscription, Governor John Penn being one of the donors. In June, 1770, the factory was opened at a house in 7th Street, between Arch and High. The following year, about twenty-three hundred pounds of silk was brought there to reel.

Many mulberry trees were now planted in New Jersey and around Philadelphia. Women devoted much of their time to the industry, as the war had cut off the usual importation of silks.

In 1770, "the celebrated Susanna Wright," of Columbia, Lancaster County, Penn., made a piece of silk from her own cocoons, sixty yards long, and also much sewing silk. Two years later, Robert Proud, the historian, visiting her home, saw fifteen hundred silkworms at work, under her charge. She thought it quite possible to raise a million worms in one season.

\section{Mulberries of MT. Vernon}

Probably with the intention of furnishing food for silk-worms, and producing silk, George Washington in March, 1765, grafted "fifteen English Mulberries on wild mulberry stocks" on the grounds of his home at Mt. Vernon, Va. As Professor Sargent observes, "there is no English Mulberry, and his scions may have been from a Black or a White Mulberry, the Chinese tree which furnishes the principal food for silk-worms."

In 1785, Washington "planted all the Mulberry trees, Maple trees and Black Gums in Serpentine Walk." A White Mulberry, sixty feet tall, with a circumference of three feet, three inches, is the only one remaining in this area. In all likelihood, it is one of those planted by the Father of his Country. 
"Boxly," the beautiful estate owned by Frederick Winslow Taylor, at Highland Station, Philadelphia, Penn., was known, over a century ago, as Mulberry Farm.

In 1803, the Count Du Barry, a friend of Joseph Bonaparte, (brother of Napoleon), purchased the property, which even then possessed historic interest, having been given by William Penn, in 1863, to Francis Daniel Pastorius, the founder of Germantown, Penn. Du Barry was an enthusiast both in landscape gardening and silk culture. He laid out the grounds of Mulberry Farm in imitation of the gardens at Versailles, France, with statuary, arbors, rare shrubs and flowers. The wonderful rows of boxwood, covering an area of six hundred feet, and still in a flourishing condition, are of his planting. The apple trees, French russets, brought from his own country, are standing today; and as their lack of vitality is becoming apparent, they are to be grafted upon young trees.

Hopeful for the success of the silk industry on his premises, Du Barry planted the necessary trees, his Mulberry Walk surviving to our own time as one of the features of the place. Two of the tiny houses erected by him for the purpose of boiling the cocoons, still remain, and between them is the old greenhouse, the front of which he covered with French roses. But like other efforts at silk-raising in the New World, his venture was doomed to failure, possibly on account of unfavorable conditions of climate.

\section{Mulberries of McSherrystown}

About the middle of the last century, interest in silk-culture in America had a brief revival. In Connecticut, several communities engaged in this business, and on Frankford Road, near Philadelphia, Penn., a Dutch family conducted it on a large scale.

A handsome avenue of mulberry trees leading to St. Joseph's Academy at McSherrystown, Penn., remains to tell the tale of similar endeavor. About 1850, they were planted there, by the Ladies of the Sacred Heart, the Sisterhood in charge. The trees flourished, but as often happens in the case of experiments, "the patients died," the silk-worms that had been imported to feed upon their foliage, refusing to thrive.

But though failing to fulfill their intended mission, the mulberries with their grateful shade, have for many a year added beauty and charm to the old convent garden. And in their early youth, these trees witnessed stirring scenes. McSherrystown is practically on the boundry between the North and South, and during the days of the Civil War, soldiers passed through the little town on their way to Gettysburg, Penn.

Pupils at the convent watched them straggling by, ragged and footsore, and offered the men their own supper, eagerly handing it 
over the wooden paling. Next day, the Sisters' only horse was commandeered. At the protest of a neighbor's boy, an officier ordered the animal returned to them, and for safe keeping, the horse was stabled in the convent kitchen. A few days later, he was the only horse available in the whole town to carry water to the wounded and dying on the field of Gettysburg. 


\section{CHAPTER XVIII}

The Stuyvesant Pear-The Endicott Pear-The Old French Pear Trees of Detroit-The Petre Pear-The Seckel Pear-Gavel Made From Historic Trees-The Traveling Nursery.

\section{The Stuyvesant Pear}

In 1644, Governor Peter Stuyesant, of New York, planted a pear tree upon the grounds of his" country home, as a token "by which his name might still be remembered"; the first instance on record in American history, of the planting of a memorial tree.

The Governor's desire has been fulfilled, for his pear tree, as well as his name, has become immortal in the chronicles of both the city and State of New York. The spot where the tree stood, (the northeast corner of Third Avenue and 13th Street, New York) was rapidly included in the growing city, and for two hundred years the old pear tree was a well known landmark. A section of its trunk is on exhibition at the rooms of the New York Historical Society, and a part of one of its limbs is preserved at City Hall. A shoot from the old pear was grafted upon a tree at the Ryder Farm at Ossining, N. Y.

\section{The Endicott Pear}

Still bearing plentifully "more fruit than the whole town can eat," the Endicott Pear tree at Danversport, Mass., is nearing the completion of its third century.

Authorities differ as to the exact time of its planting, which however, probably occurred about 1630 , during the period when Governor Endicott, one of the earliest settlers of the Bay State, was importing a large number of trees to beautify his home grounds. James Raymond Simmons tells us that "there is not much left of beauty ... about the venerable tree which still maintains its layer of living bark from year to year, around a hollow trunk, and still drops down its golden fruit into the laps of Endicott's grateful descendants and admirers. ... Soil has gradually collected about the trunk until the two main branches appear to rise from the ground as separate trees. They evidently join under a heavy covering of sod .... it is one of the most quaint and strangely impressive of all the historic trees."

\section{The Old French Pear Trees of Detroit}

In Water Works Park, Detroit, Mich., stands an ancient pear tree, whose age is estimated to be at least two hundred years. It is the sole survivor of a farm, owned by a Frenchman who named the twelve "mission pears" on his land after the twelve apostles. 
Not ordinary pear trees, these, or the others of the neighborhood, or their descendants, in any sense of the word; whether in point of size, quality of fruit produced, or reputed origin. Supposed to have been brought there by the early settlers, from Montreal, whether they had been imported from Normandy or Provence, they have been described as "the crowning glory" of the French-American orchard which was justly famed for more than one kind of superior fruit. Nearly every home possessed a pear tree. "Such was its size and productiveness that one specimen usually amply supplied the wants of a family." Strangely enough, the pears refused to grow, it is said, anywhere but in the region of Detroit and one other locality. In 1786, ColoneI Francis Navarre, of Monroe, planted half a dozen or more on his farm on the Raisin River, where they flourished. One was noted for attaining a circumference of nine feet, two inches, and at four feet above the ground its trunk forked, one branch growing to a circumference of seven feet. four inches, and the other, five feet.

The old French pear trees were still conspicuous on the bank of the Detroit River, in 1887, when Bela Hubbard described some of them as eight or nine feet in girth, and eighty feet tall, prophesying, however, that their time was short, and that they would perish along with their old homesteads "which are so fast disappearing. Another half century will see the last of those magnificent trees - the pride of the French orchard; the mammoth of fruits, of which the world does not afford its equal."

The veteran tree in Water Works Park still yields thirty to fifty bushels of fine pears annually. It is one hundred and thirty feet high, and measures four feet around the trunk. Seedlings from it refuse to grow, and this "gnarled remnant" of a proud race bids fair to leave no successor to its former glory.

There is a quaint legend concerning the origin of the trees, which tells how their career began in the garden of an early Jesuit Mission, near the site of Detroit. The old priest sat looking out over the blue waters of the river, wondering why assistance was not sent to him in his arduous labors, in response to his earnest request. Lifting his eyes, he saw a young stranger approaching, a Frenchman, bringing with him a letter from the Superior of the Order. It contained a brief history of the young foreigner, who had fallen hopelessly in love with one of his countrywomen. She was unhappily married, and in retaliation for her lover's attentions, was murdered by her husband. Heart-broken, the former was seeking some means of forgetting his grief. "Put him to work," urged the letter, "and work him as hard as you will, or his life will be wasted."

The Father complied, and found the newcomer a valuable assistant, eager to fulfill all his duties. Often, however, at sunset, he would stand alone, looking wistfully over the river, and fondling a withered pear-blossom which he had brought from his home-land. 
Watching him long and thoughtfully, the old priest sought for the right word to speak, and at length suggested that he should plant the seeds hidden in the faded flower, and let them bring forth rich fruit for the good of the community, and thus do what was in his power to atone for his "unblest affection."

\footnotetext{
*"In thy withered pear lies dormant Nature's power to bloom and bless This unfruitful wilderness.

Here is healing for thy torment!

Many and many a voice of prayer

Long may bless thy withered pear.

Thus, like souls redeemed from sin,

Did the mission pears begin

In the ancient Jesuit garden;

And the shoots, as they ascended,

Prayerfully were watched and tended

Till the wood could grow and harden,

Often, in their early years,

Watered by repentant tears."
}

\section{The Petre Pear}

In Bartram's Garden, Philadelphia, Penn., a small, gnarled pear tree perpetuates the memory of Lady Petre, of England, who, in 1760, sent it across seas to the famous botanist. It was planted close by the quaint old house on the Schuylkill, that during his life-time was a centre of hospitality, and where noted men were often entertained. Owing to the generosity of Lord Peter, the Duke of Richmond and Peter Collinson, who justly subscribed a fund for the purpose, Bartram was able to continue the expeditions which he had begun in order to collect and classify the plants of the New World, returning to the donors the equivalent in roots and seeds.

\section{The Seckel Pear}

The original Seckel pear tree grew on a strip of land called The Neck, five miles south of Philadelphia, Penn., on the property of Lawrence Seckel, a prominent wine merchant of the city. The place, which was his country seat, was later owned by the well known citizen, Stephen Girard. It was near Wilton, a famous watering-place prior to the Revolution.

In 1819, Dr. Hosack sent some of the small "spicy and honeyed" fruit to the London Horticultural Society, which rated them as "exceeding in flavor the richest of the autumn pears." The doctor stated that this unique tree had first become known in Philadelphia about seventy years before.

Where the tree came from, no one knew, not even Mr. Seckel himself. About the middle of the 18th Century the Swedes, Dutch and Germans imported a great number of trees, shrubs and flowers from the Old World, and it was supposed that the far-famed Seckel pear had found its entrance into the country in this way.

\footnotetext{
* From poem by J. L. Bates.
} 
The site where the Seckel home once stood is now "a region given over to the growth of plethoric cabbages, endless tomatoes, and onions infinite." Near the old farm-house is a white post which marks the location of the Seckel pear, the tree itself having succumbed to a wind-storm in 1905. A shoot from it was grafted upon a tree nearer the house.

\section{Gavel Made From Historic Trees}

The fashioning from historic wood, of a gavel, presented to the Fifth Pacific Coast Congress of Congregational Churches, held in Portland, Ore., in 1911, has brought to light some interesting facts in connection with the material used. Ejach piece of wood in the gavel was numbered to correspond with a printed list of descriptions. Two of the sections were taken from fruit trees, an apple and a cherry, representing events in the history of the early settlements of the great North West.

One of these was from a seedling apple, a tree which grew near the Hudson Bay Company's Fort, Vancouver, now Vancouver, Wash., from seed brought from London to that place in 1825. Mrs. Narcissa Prentiss Whitman, one of the two first American women to cross the plains to Oregon, arrived at Fort Vancouver on September 12, 1836, and her husband, Dr. Marcus Whitman, and her traveling companions-Rev. Henry H. Spalding, Mrs. Eliza Hart Spalding and William H. Gray-were entertained by Dr. John McLoughlin, Chief Factor of the Hudson Bay Company. Mrs. Whitman, in her diary under the date above mentioned, made the following entry:

"What a delightful place this is; what a contrast to the rough, barren sand plains through which we have so recently passed. Here we find fruit of every description-apples, peaches, grapes, pears, plums and fig trees in abundance; also cucumbers, melons, beans, peas, beets, cabbage, tomatoes, and every kind of vegetable, too numerous to be mentioned. Every part is very neat and tastefully arranged, with fine walks, lined on each side with strawberry vines. At the opposite end of the garden is a good summer house covered with grape vines. Here I must mention the origin of these grapes and apples. A gentleman, twelve years ago, while at a party in London, put seeds of the grapes and apples which he ate into his vest pocket; soon afterwards he took a voyage to this country and left them here, and now they are greatly multiplied."

\section{The Traveling Nursery}

The piece of cherry wood used in the gavel is of the variety known as the Royal Ann, and acquaintance with it opens up a little known page in the development of the western fruit industry. The Royal Ann, in company with seven hundred other fruit trees, belonged to the Traveling Nursery, which was brought across the plains in 1847, by Henderson Lewelling, of Salem, Henry County, Iowa. 
Though repeatedly warned that his undertaking was hopeless, Lewelling persisted in his cherished scheme of establishing a nursery in the "densely wooded North West," many leading varieties of apples and pears, some plums and cherries, one Isabella grape vine and one gooseberry plant were among the trees and shrubs, which packed in carefully prepared soil, were loaded upon his wagon and ox-teams.

Journeying through "dry, thirsty land and over lofty mountain ranges," he reached Milwaukee, Wis., about October 1, 1847, with most of the trees alive. There he established his first nursery, and continued his way to the Pacific Coast.

Ralph Geer, another pioneer of that same year, says, "That load of trees contained health, wealth and comfort for the old pioneers of Oregon. It was the mother of all the orchards west of the Rocky Mountains, and gave Oregon a name and fame that she never would have had without it. That load of living trees brought more wealth to Oregon than any ship that ever entered the Columbia River."

Incidentally, Lewelling founded. during his travels, four towns by the name of Salem, in memory of his birthplace; Salem, N. C., Salem, O., Salem, Ind., Salem, Iowa, and Salem, Ore., all owe their origin to him. 


\section{CHAPTER XIX}

Johnny Appleseed and His Trees-Roger Williams' Apple Tree.

\section{Johnny Appleseed and His Trees}

During the years from 1806 to 1830 , John Chapman, familiarly known as "Johnny Appleseed," one of the most unique philanthropists known to history, was engaged in his self-imposed mission of planting apple trees for the benefit of the earliest settlers in Ohio. Going in advance of civilization, unarmed and unafraid, amidst the perils of the wilderness, it was his ambition to have the fruit-trees flourishing to greet the influx of pioneers, who, but for his unselfish thought and work, would sadly have missed the accustomed orchards of their homeland.

"He began his apple mission in Pennsylvania in 1802 or 1803," says A. J. Baughman, one of his historians, "but soon transferred his field to Ohio. He made frequent visits to the Keystone State for apple seeds, and on his return selected favorable spots for his pioneer nurseries. He sought fertile soil and sheltered places, and often made clearings to give his tender shoots protection from wind and blizzard. As one section of the State became supplied with trees, he moved to another.

"The early settlers were too busy in wresting a livelihood from nature and in fighting Indians, to engage in the slow process of raising apple trees from seed, and Chapman, full of faith in the virtue of the fruit, took upon himself the duty of supplying the need. Usually a man of few words, he became eloquent when speaking of apples, and his fine flow of language gave the impression that he had been well educated."

He planted his first nursery at Lagrange, O., opposite Wellsburg, W. V. After planting others along the Ohio River, he continued into Richland County, where he made his home in a little cabin for several years. "Johnny Appleseed," as he had been affectionately christened by the inhabitants, now had his hands full.

Planting orchards in a number of counties, he made the rounds, yearly, traveling hundreds of miles to prune and care for his trees, which were generally planted on or near streams, and protected with a brush fence. An inestimable blessing they must have been to the pioneers, a pleasant welcome in the midst of unfriendly surroundings. Johnny's price for a tree was usually, "fip penny-bit," or he would give credit or accept clothes in exchange.

The Ohio Archaeological and Historical Quarterly has reproduced an autograph order of Chapman's which reads as follows: 
"Due John Cheever one hundred and fifty trees when he goes for them to some of my nurseries on Mohecan waters."

\section{"John Chapman."}

It is doubtful that any of "Johnny's" trees have survived to the present day, but to quote from General Roeliff Brinkerhoff's Mansfield, O., "Within the sound of my voice, where I now stand there are a dozen or more trees that we believe are the lineal descendants of Johnny Appleseed's nurseries. In fact, this monument is almost within the shadow of three or four of them." Richland County owned all of its early orchards to the nurseries of the "Apostle of Apples" as he has been called. In the woods, he sowed various medical plants.

Johnny was a welcome guest in many homes, but much of his time was, necessarily spent in journeys through the forest, from the site of one orchard to another. His dress was peculiar. $\mathrm{He}$ went barefoot, and often wore a coffee sack, with hole cut for his head and arms, instead of a coat. He took with him a bundle of cooking utensils, often wearing his mush-pan for a hat. Occasionally, however, he wore one made of cardboard, with a broad brim. But no weapon of any description was among his effects. Neither savage nor animal would harm the gentle horticulturist, the former looking upon him as a great "Medicine Man."

He loved and reverenced life in its lowest forms as well as in its higher manifestations, and it has been said that he "deserved to be the patron saint of the Humane Society, of which he was certainly the earliest forerunner." He purchased any animal that he saw ill-treated, any worn out horses, turned away to starve, and found for them homes where they/were kindly cared for. "It is further recorded," says Mr. E. O. Randall, "that he would never sell these poor and despised animals, but if any of them recovered their strength so as to be valuable, he would lend them or give them away, exacting a promise from the recipient that the dumb beast should ever receive kind treatment."

The friend of every living creature, he was willing to journey thirty miles through the forest to obtain help for his fellow men when Mansfield, O., was threatened with an Indian raid, or to relinquish a night's shelter in a hollow log rather than disturb the frightened squirrel who had housed her family inside.

In his later years, Chapman found a new field for his planting in Indiana, where he died, in 1847, at the age of seventy-two. It has been said "that although years have,come and gone since his death, the memory of his good deeds lives anew every springtime in the beauty and fragrance of the blossoms of the apple trees he loved so well.

\section{Roger Willifams' Apple Tree}

There are tall and stately trees in Rhode Island, still casting 
their welcome shade, that were saplings in the days of Roger Williams, nearly three hundred years ago; and tradition credits him with planting the Congdon Street American elm, one of the best known trees of Providence, though the story is not considered authentic. Strangely enough, it is an old apple tree with which he had no association in life, that remains inseparably linked with his memory.

In 1636, Roger Williams, one of the most famous of the pioneers who came from England to the New World in quest of civil and religious freedom, settled in Rhode Island. Boston, where he had lived for a few years, proved a dangerous place for a man of his liberal views, which were little to the liking of the Puritans. Chief among his offenses was his refusal to acknowledge the right of the Commonwealth either to punish for spiritual delinquencies or to bar everyone except church members from voting on civil affairs, while at the same time, all, irrespective of creed, were taxed to support the church.

He had already left Boston for Salem, Mass., when the authorities pronounced a sentence of banishment upon him and sent a sloop to take him back to England.

Aware of the fate that was planned for him, however, Williams escaped from Salem to Narragansett Bay, wisely selecting a place free "from any English claims or patents." There is a tradition to the effect that, as he and his little party sailed down Seekonk River and rounded "Slate Rock," some friendly Indians called out, "What cheer, Netop?"

Near the Mooshausick River, he and his companions founded Providence, the first settlement in Rhode Island. As he stated in the deed drawn in 1661, he "desired it might be for a shelter for persons distressed in conscience." Everyone who settled there was required to sign a statement that he pledged himself to submit to its government "only in civil things."

When Roger Williams' noble life-work ended, in 1684, he was buried in a spot selected by himself, on the hill-side near his first landing.

In after years, when the growth of the town rendered it necessary to remove the bodies of the early settlers interred there, it was found that an apple tree had sent its roots into his grave, and that they had followed the outline of the human form. This curious occurrence has been twice commemorated in verse.

M. E. Buhler speaks of the great pioneer's character as follows:

"All that he had he used, to give

That others might more freely live-

In life and death he gave;

For when his valiant soul went free

Whose passion was for liberty,

His dust became an apple tree

Above his empty grave. 
Its roots so quaintly human form

Had grown thro' sunshine and thro' storm, Beside the grassy spring,

And its great boughs bent down to shield

The wayworn pilgrim and to yield Sweet fruit and comforting."

It has been often and truly said that there is only a step between the sublime and the ridiculous, and the familiar words are well illustrated in the "skit" by Charles T. Miller, published in 1874, humorously tracing the influence of Williams' indomitable spirit, down through the historic Dorr Rebellion into modern times.

"Did you ever hear the story told

Of Roger Williams, the preacher bold,

Who settled this State in the days of old, This little State of Rhode Island?

In sixteen hundred and thirty-six,

Roger Williams got into a fix,

By saucing the Governor of Massachusetts,

And skedaddled away to Rhode Island.

He crossed, as everybody knew,

Seekonk River in a birch canoe;

Just to save the tolls that were due

On the bridges above and below him.

The college boats are always out,

They'd have taken him over, I haven't a doubt;

But Roger was mad and stuffed it out

And "paddled his own canoe."

When on Slate Rock a footing was found, The Abby Origenes were sitting around; And Roger, thinking he'd like to sit down, He quietly asked, "What cheer?"

The Indians thought it exceedingly cool, And said, "We have neither chairs nor stool; So sit down on the rock, you fussy old fool, As all the rest of us do."

By the sweat of his brow, I've heard it said, He paid his way and earned his bread;

And when he gets sufficiently dead,

They'll put a monument over him.

They buried him carefully, away from harm,

In a quiet old orchard on his own farm,

'Twas right in back of Governor Dorr's barn,-

And supposed that he'd keep quiet.

But a jolly old apple tree rooting around,

Seeking for phosphates under the ground,

Followed his back-bone all the way down,

And old Mother William's too.

What's bred in the bone, in the flesh will show, What's bred in the root, the fruit will know; For two hundred years this fruit did grow 'Till posterity ate him up.

In 'forty-two he got up a war

By having got into Governor Door,

By eating the apples, just as you saw;

So there was another row.

'Tis Williams' fault, as we all know now,

Apples have always caused a row

From Adam's time, way down to now;

So they dug Mr. Williams up.

So they dug up the roots and the coffin nails,

To be planted again in boxes or pails;

And unless a big stone monument falls,

This time they'll keep him down." 


THIS BOOK IS DUE ON THE IAAST DATE
STAMPED BELOW

AN INITIAL FINE OF 25 CENTS WILL BE ASSESSED FOR FAILURE TO RETERTY THIS BOOK ON THE DATE DUE. ON THE FOURTH THIS INCREASE TO 50 CEN THE SEVENTH DAY

WAY AND TO $\$ 1.00$ OVERDUE.

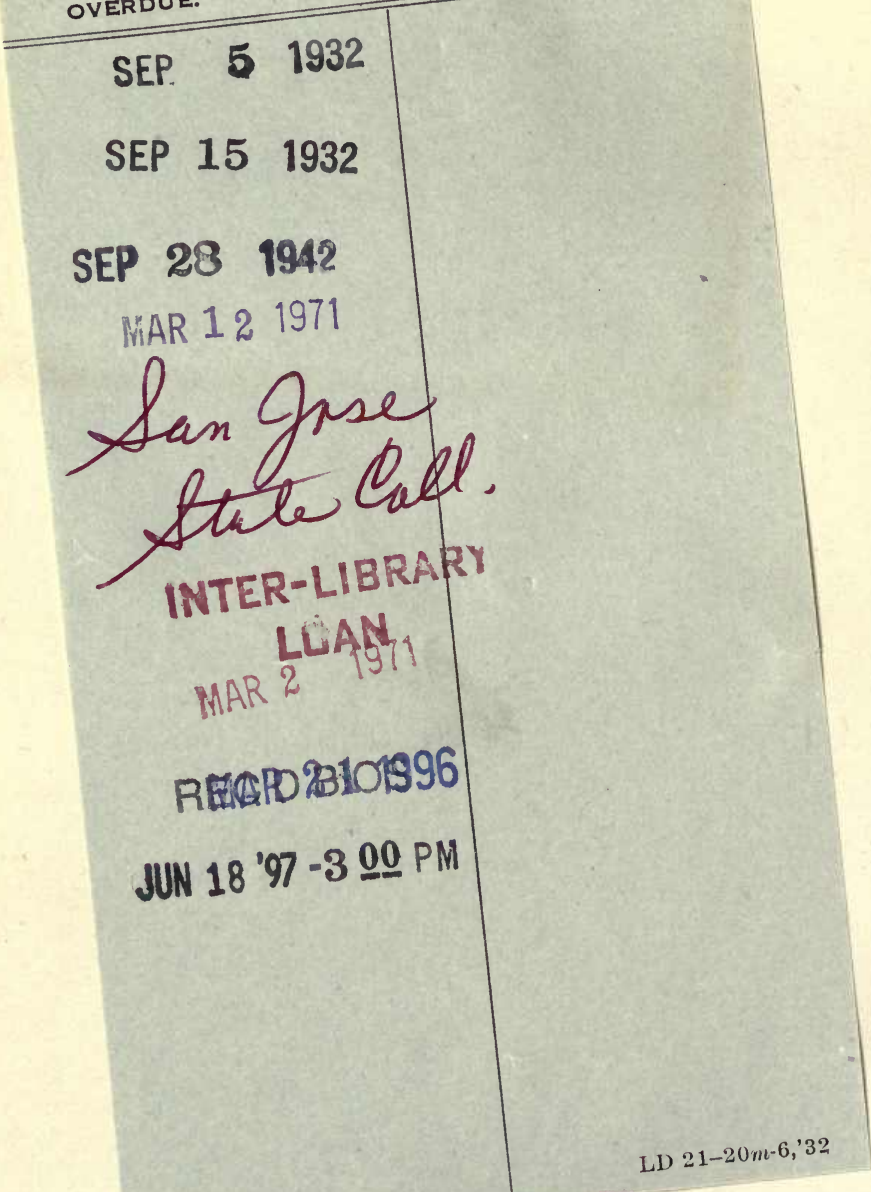




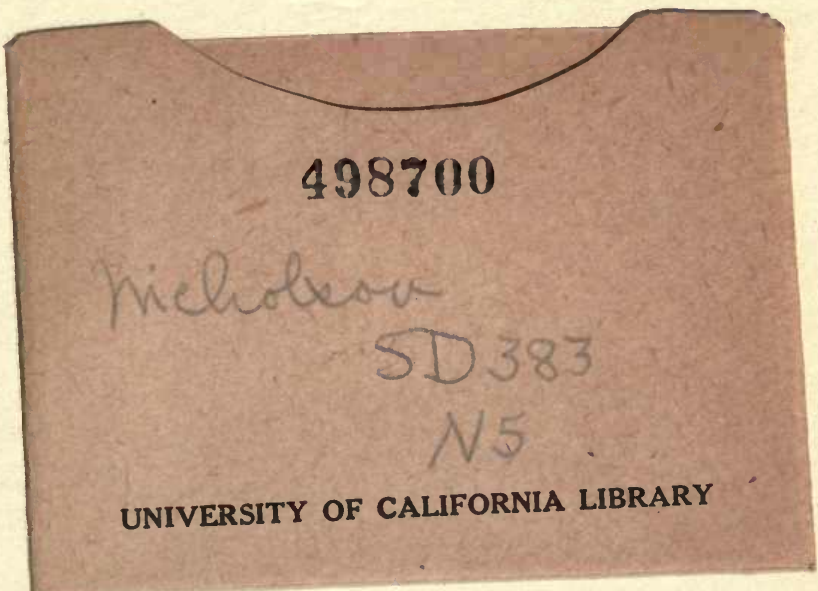


